Marquette University Law School

Marquette Law Scholarly Commons

Faculty Publications

Faculty Scholarship

$1-1-2000$

\title{
The Influence of Amicus Curiae Briefs on the Supreme Court
}

Joseph D. Kearney

Marquette University Law School, joseph.kearney@marquette.edu

Thomas W. Merrill

Columbia Law School

Follow this and additional works at: http://scholarship.law.marquette.edu/facpub

Part of the Law Commons

Publication Information

Reproduced with permission of the University of Pennsylvania Law Review, from Joseph D. Kearney

\& Thomas W. Merrill, The Influence of Amicus Curiae Briefs on the Supreme Court, 148 U. Pa. L.

Rev. 743 (2000); permission conveyed through Copyright Clearance Center, Inc.

\section{Repository Citation}

Kearney, Joseph D. and Merrill, Thomas W., "The Influence of Amicus Curiae Briefs on the Supreme Court" (2000). Faculty Publications. Paper 568.

http://scholarship.law.marquette.edu/facpub/568

This Article is brought to you for free and open access by the Faculty Scholarship at Marquette Law Scholarly Commons. It has been accepted for inclusion in Faculty Publications by an authorized administrator of Marquette Law Scholarly Commons. For more information, please contact megan.obrien@marquette.edu. 


\title{
THE INFLUENCE OF AMICUS CURIAE BRIEFS ON THE SUPREME COURT
}

\author{
JOSEPH D. KEARNEY ${ }^{\dagger}$ AND THOMAS W. MERRILL ${ }^{\#}$
}

INTRODUCTION AND OVERVIEW .744

I. THE RISING TIDE OF AMICUS CURIAE BRIEFS.................................751

A. The Level of Amicus Curiae Activity, 1946-1995 ...........................751

B. Citation and Quotation of Amicus Briefs, 1946-1995....................757

II. THE OPEN DOOR POLICY TOWARD AMICUS BRIEFS .........................761

III. PREVIOUS STUDIES OF THE INFLUENCE OF AMICUS BRIEFS ON SUPREME COURT OUTCOMES .....................................7767

IV. THREE MODELS OF JUDGING AND THEIR IMPLICATIONS FOR AMICUS BRIEFS ..........................................................................774

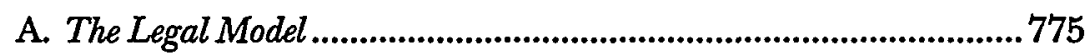

B. The Attitudinal Model..............................................................779

C. The Interest Group Model .........................................................782

V. AN EMPIRICAL STUDY OF THE INFLUENCE OF AMICUS BRIEFS ..........787

A. The Overall Success Rates of Amicus Filers.................................... 789

B. Disparities in Amicus Support....................................................793

C. The Impact of Amicus Brief Quality................................................801

1. Success Rates of Institutional Litigants ..............................801

2. Success Rates of Cited Briefs ...............................................811

† Assistant Professor of Law, Marquette University. B.A., 1986, Yale University; J.D., 1989, Harvard University.

† John Paul Stevens Professor of Law, Northwestern University. B.A., 1971, Grinnell College; B.A., 1973, Oxford University; J.D., 1977, University of Chicago. The authors express their appreciation to Robert W. Bennett, Ashutosh Bhagwat, Shari S. Diamond, John Mark Hansen, Richard J. Lazarus, James Lindgren, Craig Allen Nard, Christopher M. Rohrbacher, Gerald N. Rosenberg, Nancy Scherer, James B. Speta, and the participants in the American Politics Workshop at the University of Chicago and the Georgetown University Law Center Supreme Court Institute for helpful comments on previous drafts of this paper; to Michael R. Borovik, Joel F. Knutson, Michael N. Levy, and John van Voorhis for statistical assistance; and to Nicholas A. Brannen, Tara C. Campbell, Margaret M. Johnson, Thomas D. Noonan, and Andrew T. O'Neill for research assistance. 
3. Success Rates of Briefs Filed by

More Experienced Lawyers...............................................813

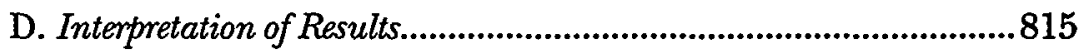

VI. RECONSIDERING THE RISING TIDE OF AMICUS BRIEFS......................819

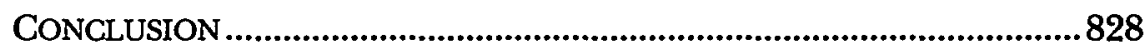

APPENDIX A: CASES WTTH TWENTY OR MORE AMICUS BRIEFS, 1946-1995

APPENDIX B: DATA-GATHERING METHODOLOGY...........................8835

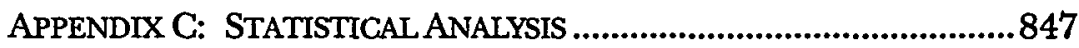

\section{INTRODUCTION AND OVERVIEW}

The last century has seen little change in the conduct of litigation before the United States Supreme Court. The Court's familiar procedures-the October Term, the opening-answering-reply brief format for the parties, oral argument before a nine-member Court-remain essentially as before. The few changes that have occurred, such as shortening the time for oral argument, have not been dramatic.

In one respect, however, there has been a major transformation in Supreme Court practice: the extent to which non-parties participate in the Court's decision-making process through the submission of amicus curiae, or friend-of-the-court, briefs. Throughout the first century of the Court's existence, amicus briefs were rare. ${ }^{1}$ Even during the initial decades of this century, such briefs were filed in only about $10 \%$ of the Court's cases. ${ }^{2}$ This pattern has now completely reversed itself. In recent years, one or more amicus briefs have been filed in $85 \%$ of the Court's argued cases. ${ }^{3}$ Thus, at the close of the twentieth century, cases without amicus briefs have become nearly as rare as cases with amicus briefs were at the beginning of the century.

${ }^{1}$ Although dated, the best history of amicus curiae briefs in the Supreme Court remains Samuel Krislov, The Amicus Curiae Brief: From Friendship to Advocacy, 72 YALE L.J. 694 (1963). The first recorded appearance of an amicus curiae in the Supreme Court occurred in 1821, see Green v. Biddle, 21 U.S. (8 Wheat) 1 (1823), which perhaps not coincidentally was the first year the Court accepted written briefs for filing. See DAVID M. O'BRIEN, STORM GeNIER: THE SUPREME COURT IN AMERICAN POIITICS 146 (1986).

${ }^{2}$ See Steven Puro, The Role of Amicus Curiae in the United States Supreme Court: 1920-1966, at 56 tbl.III-1 (1971) (unpublished Ph.D. dissertation, State University of New York at Buffalo) (on file with the University of Pennsylvania Law Review).

${ }^{3}$ See infra Figure 23 (presenting specific data evidencing the increased filing of amicus briefs). 
Attitudes within the legal community about the utility and impact of amicus briefs vary widely. Perhaps the most common reaction among lawyers and judges is moderately supportive. Amicus briefs, it is said, can provide valuable assistance to the Court in its deliberations. ${ }^{4}$ For example, they can present an argument or cite authorities not found in the briefs of the parties, and these materials can occasionally play a critical role in the Court's rationale for a decision. ${ }^{5} \mathrm{Al}-$ ternatively, these briefs can provide important technical or background information which the parties have not supplied. ${ }^{6}$ Those sharing this perspective can point to the frequent citation of amicus briefs in the Justices' opinions in support of the supposition that the Court often finds such briefs helpful.

Other members of the legal community, however, offer a much more negative assessment of amicus briefs. For example, Chief Judge Richard Posner of the Seventh Circuit has written that the amicus briefs filed in his court provide little or no assistance to judges because they largely duplicate the positions and arguments advanced by the parties. ${ }^{8}$ Those who share this assessment regard such filings as

${ }^{4}$ See, e.g., Edmund Ruffin Beckwith \& Rudolf Sobernheim, Amicus Curiae-Minister of Justice, 17 FORDHAM L. REv. 38 (1948); Luther T. Munford, When Does the Curiae Need an Amicus?, 1 J. APP. PRAC. \& PROCESS 279, 281-83 (1999).

5 The Court will on occasion base its decision on a point or argument raised only in an amicus brief. See, e.g., Teague v. Lane, 489 U.S. 288, 300 (1989) (plurality opinion of O'Connor, J.) (ruling against petitioner on question of retroactivity even though the issue "has been raised only in an amicus brief"); Oregon ex. rel. State Land Bd. v. Corvallis Sand \& Gravel Co., 429 U.S. 363, 368 n.3, 382 (1977) (overruling an earlier case even though this action was urged only by amici); Mapp v. Ohio, 367 U.S. 643, 646 n.3 (1961) (overruling Wolf v. Colorado, 338 U.S. 25 (1949), and adopting exclusionary rule in cases of Fourth Amendment violations by state officials, even though that course of action had been urged only by amicus ACLU). As a general rule, however, the Court will not address issues raised only by an amicus. See, e.g., DelCostello v. International Bhd. of Teamsters, 462 U.S. 151, 154 \& n.2 (1983) (citing United Parcel Serv., Inc. v. Mitchell, 451 U.S. 56, 60 n.2 (1981), and noting the Court's hesitation to address an issue raised only by an amicus).

${ }^{6}$ Cf. Justice Breyer Calls for Experts to Aid Courts in Complex Cases, N.Y. TMES, Feb. 17, 1998, at Al7 (quoting Justice Breyer as stating that " [amicus] briefs play an important role in educating judges on potentially relevant technical matters, helping to make us not experts but educated lay persons and thereby helping to improve the quality of our decisions").

${ }^{7}$ See infra text following note 40 (analyzing the frequency of references to amicus briefs in the Court's opinions).

${ }^{8}$ In an order explaining why he was denying leave to file a brief amicus curiae, Judge Posner wrote the following:

After 16 years of reading amicus curiae briefs the vast majority of which have not assisted the judges, I have decided that it would be good to scrutinize 
largely a nuisance-imposing unwarranted burdens on judges and their staffs with few, if any, mitigating benefits. According to those who harbor this negative assessment, the judicial system would be improved if amicus filings were prohibited or at least sharply curtailed. ${ }^{9}$

Justice Scalia recently offered a third perspective on the widespread filing of amicus briefs. The occasion was Jaffee $v$. Redmond, where the Supreme Court recognized a "psychotherapist's privilege" under Rule 501 of the Federal Rules of Evidence. In a dissenting opinion joined in part by Chief Justice Rehnquist, Justice Scalia offered the following observation:

In its consideration of this case, the Court was the beneficiary of no fewer than 14 amicus briefs supporting respondents, most of which came from such organizations as the American Psychiatric Association, the American Psychoanalytic Association, the American Association of State Social Work Boards, the Employee Assistance Professionals Association, Inc., the American Counseling Association, and the National Association of Social Workers. Not a single amicus brief was filed in support of petitioner. That is no surprise. There is no self-interested organization out there devoted to pursuit of the truth in the federal courts. The expectation is, however, that this Court will have that interest prominently-indeed, primarily -in mind. Today we have failed that expectation, and that responsibility.

Justice Scalia's reference to "self-interested organizations" and his lack of surprise in finding no amicus arguing against creation of an evidentiary privilege suggest that amicus briefs reflect a form of interest group lobbying directed at the Court. His remarks further suggest,

these motions in a more careful, indeed a fish-eyed, fashion.

The vast majority of amicus curiae briefs are filed by allies of the litigants and duplicate the arguments made in the litigants' briefs, in effect merely extending the length of the litigants' brief. Such amicus briefs should not be allowed.

Ryan v. Commodity Futures Trading Comm'n, 125 F.3d 1062, 1063 (7th Cir. 1997) (Posner, J., in chambers).

${ }^{9}$ Among Supreme Court Justices, Robert Jackson at least occasionally expressed such a view of amicus briefs. In Craig v. Harney, 331 U.S. 367 (1947), Jackson made the following remark about the amicus brief filed by the American Newspaper Publishers Association:

[I]t does not cite a single authority that was not available to counsel for the publisher involved, and does not tell us a single new fact except this one: "[The Association's] membership embraces more than 700 newspaper publishers whose publications represent in excess of eighty per cent of the total daily and Sunday circulation of newspapers published in this country."

Id. at 397.
518 U.S. 1 (1996).
11 Id. at 35-36 (Scalia, J., dissenting). 
in keeping with the interest group theory of politics, ${ }^{12}$ that wellorganized interest groups will be more likely to file amicus briefs than will diffuse and poorly organized interests. Most significantly, Justice Scalia intimates that the over-representation of well-organized interest groups through amicus filings may have an influence on the outcomes reached by the Court. He at least suggests that this is what happened in Jaffee, in which the highly disproportionate amicus support for the respondent may have sent a clear signal to the Court that a decision recognizing a psychotherapist's privilege would more likely receive acclaim from organized groups than one rejecting such a privilege.

The critical but unstated variable that divides these different perspectives is the model of judicial decision making adopted by each commentator. Each of the three positions corresponds to a different model of judging, which in turn suggests a different pathway of influence that amicus briefs may have on the outcomes reached by courts. ${ }^{13}$

The first or moderately supportive view of amicus briefs implicitly

${ }^{12}$ See, e.g., NEAL K. KOMESAR, IMPEREECT AITERNATTVES: CHOOSING INSTITUTIONS IN LAW, ECONOMICS, AND PUBLIC POLICY 53-97, 123-50 (1994) (explaining the interest group theory of politics and arguing for its extension to judicial processes); Einer $\mathbf{R}$. Elhauge, Does Interest Group Theory Justify More Intrusive Judicial Review?, 101 YALE L.J. 31, $35-48$ (1991) (arguing that judicial processes are subject to the same interest group dynamics as other political processes).

${ }^{15}$ We do not mean to suggest that Judge Posner, who has expressed skepticism about the value of amicus briefs, see supra note 8 and accompanying text, or Justice Scalia, who has suggested that amicus briefs may reflect a form of interest group lobbying, see supra text accompanying note 11 , is necessarily committed to the explanatory models of judging we associate with their remarks.

In writings about judicial behavior, Judge Posner has suggested that appellate judges are primarily motivated by the pleasure they derive from participating in the "spectator's game" of deciding cases. See RICHARD A. POSNER, OVERCOMmng LAW 12635 (1995) [hereinafter POSNER, OvERCOMING LAW]; Richard A. Posner, What Do Judges and Justices Maximize? (The Same Thing Everybody Else Does), 3 SUP. CT. ECON. REv. 1, 2330 (1994) [hereinafter Posner, What do Judges and Justices Maximize?]. This theory does not precisely conform to any of the three models of judging we will discuss, but in practice it would appear to fall closer to the legal model than to either the attitudinal model or the interest group model. If judging is like observing a game of tennis or chess, then presumably an important part of the process is understanding and following the rules of the game.

Justice Scalia, to our knowledge, has not offered a positive theory of judging. But his normative writing clearly presupposes that judges are profoundly constrained by legal rules. See ANTONIN SCALIA, A MATTER OF INTERPRETATION: FEDERAL COURTS AND TFE LAW 3, 44-47 (1997) (arguing that an evolutionary interpretation of the Constitution is destructive of its purpose); Antonin Scalia, The Rule of Law as a Law of Rules, 56 U. CFI. L. REV. 1175, 1177 (1989) (arguing against unlimited judicial discretion). Thus, he too would presumably endorse the legal model as an explanation for judging-at least when judging is done correctly. 
adopts the conventional legal model of judicial decision making. Under this model, judges are regarded as seeking to resolve cases in accordance with the requirements of law, as understood by professional actors in the legal community. Amicus briefs are assumed to have an impact on this process insofar as they contain new information-legal arguments and background factual material-that would be relevant to persons seeking the correct result in light of established legal norms.

The second or sharply negative view is often associated with what political scientists call the "attitudinal model" of judicial behavior. ${ }^{14}$ This model posits that judges have fixed ideological preferences, and that case outcomes are a product of the summing of the preferences of the participating judges, with legal norms serving only to rationalize outcomes after the fact. Under this view, amicus briefs should have little or no impact on the outcomes reached by a court, because each judge's vote in a case is assumed to be the product of his or her preestablished ideological preferences with respect to the issue presented. A judge can obtain all the information needed to determine his or her vote, the attitudinal model would suggest, by reading the "Question Presented" and the statement of facts contained in the parties' briefs. To the extent that amicus briefs provide additional legal arguments and factual background, under this model they offer information of no relevance to judges.

The third view, which we have extrapolated from Justice Scalia's comments in Jaffee, implicitly adopts an interest group theory of the judicial process. In contrast to the attitudinal model, the assumption here is that judges do not have strong ideological preferences about most issues. Rather, they are empty vessels who seek to decide cases so as to reach those results supported by the most influential groups in society that have an interest in the question at hand. Amicus briefs on this view should be important to the judicial process because of the signals that they convey about how interested groups want particular cases decided. If, as in Jaffee, the groups filing amicus briefs all want a case to come out a certain way, this tells the judges how to rule if they want to secure the approval of organized groups.

The question of how amicus briefs influence judicial outcomes is one as to which, in principle, empirical information can be gathered.

${ }^{14}$ See Jefrrey A. Segal \& Harold J. Spaeth, The Supreme Court aNd the ATITIUDINAL MODEL 65-73 (1993) (describing the rationale and historical antecedents of the attitudinal model). 
Unfortunately, when courts devise policies regarding the filing of amicus briefs, and when lawyers advise clients about filing such briefs, they almost always proceed on the basis of anecdotal information or recent episodes that may be unrepresentative of the larger universe of amicus curiae participation. What is worse, this highly fragmentary information may be processed through a perceptual lens based on a particular implicit model of judging, which model, again, is untested and may or may not be a reliable guide to underlying realities.

In this Article, we present empirical evidence designed to enhance our understanding about the impact of amicus curiae briefs on the Supreme Court and therefore also about the validity of different models of judging. To this end, we have assembled a large database consisting of fifty years of Supreme Court merits decisions-every argued case from the 1946 Term through the 1995 Term. For each decision, we recorded, among other things, the outcome of the case, the number of amicus briefs supporting the petitioner, the number supporting the respondent, and whether certain key institutional litigants filed amicus briefs in the case. ${ }^{15}$ We then analyzed these data using standard statistical techniques to try to differentiate between different hypotheses about the influence of amicus briefs on judicial behavior.

Briefly, our principal findings are as follows. First, our study shows conclusively that the incidence of amicus curiae participation in the Supreme Court has increased dramatically over the last fifty years. While the number of cases that the Court has disposed of on the merits has not appreciably increased during this time (indeed it has fallen in recent years), the number of amicus filings has increased by more than $800 \%$.

In terms of the influence of amicus briefs on outcomes, our study uncovers a number of interesting patterns. We find that amicus briefs supporting respondents enjoy higher success rates than do amicus briefs supporting petitioners; that small disparities of one or two briefs for one side with no briefs on the other side may translate into higher success rates but larger disparities do not; that amicus briefs cited by the Court appear to be no more likely to be associated with the winning side than briefs not cited by the Court; and that amicus briefs filed by more experienced lawyers may be more successful than briefs filed by less experienced lawyers. Among institutional litigants that appear frequently before the Court, we confirm the finding of other

${ }^{15}$ For a detailed explanation of our methodology in assembling the database, see infra Appendix B. 
researchers that the Solicitor General, who represents the United States before the Supreme Court, enjoys great success as an amicus filer. We also track the amicus records of the American Civil Liberties Union ("ACLU"), the American Federation of Labor-Congress of Industrial Organizations ("AFL-CIO"), and the States, and find that they enjoy some success as amicus filers, although less than the Solicitor General.

We cautiously interpret these results as providing more support for the legal model than for either the attitudinal or interest group models. Contrary to what the attitudinal model would predict, amicus briefs do appear to affect success rates in a variety of contexts. And contrary to what the interest group model would predict, we find no evidence to support the proposition that large disparities of amicus support for one side relative to the other result in a greater likelihood of success for the supported party. In fact, it appears that amicus briefs filed by institutional litigants and by experienced lawyers-filers that have a better idea of what kind of information is useful to the Court-are generally more successful than are briefs filed by irregular litigants and less experienced lawyers. This is consistent with the legal model's prediction that amicus briefs have an influence to the extent they import valuable new information. Moreover, the greater success associated with amicus briefs supporting respondents can be explained by the supposition that respondents are more likely than petitioners to be represented by inexperienced lawyers in the Supreme Court and hence are more likely to benefit from supporting amici, which can supply the Court with additional legal arguments and facts overlooked by the respondents' lawyers.

The Article is organized as follows. Part I provides an overview of amicus curiae activity in the Supreme Court over the last fifty years, tracking the increase in amicus filings and in the Court's citation and quotation of such briefs. Part II traces the emergence of the Court's open door policy toward amicus filings starting in the late 1950s, and the impact of this policy on the frequency of amicus filings. Part III reviews the conflicting results of previous studies that have sought to measure the influence of amicus briefs on the Supreme Court. Part IV posits three models of judicial behavior that underlie commentary about amicus curiae briefs and sets forth the hypotheses about amicus influence associated with each model. Part V summarizes the major findings of our empirical survey. Part VI closes with some reflections on the factors that may account for the surge in amicus curiae activity in the Supreme Court in the last fifty years. 


\section{THE RISING TIDE OF AMICUS CURIAE BRIEFS}

Amici curiae today play an integral role in Supreme Court litigation. In this Part, we offer a statistical overview of how the frequency of amicus participation has changed in the last fifty years to the point where amicus briefs have become an everyday occurrence in Supreme Court practice. We also provide a comprehensive survey of the incidence of citation and quotation of amicus briefs by the Justices. Previous studies have provided partial descriptions or intimations of these phenomena. Our study confirms these accounts and fills in the details.

\section{A. The Level of Amicus Curiae Activity, 1946-1995}

The phenomenon of increasing amicus participation in the Supreme Court was not evident to all while it was taking shape. Writing in the 1960s, Nathan Hakman was able to argue that amicus curiae influence on the Supreme Court was exaggerated-an example of "Political Science Folklore," as he put it. ${ }^{16}$ Hakman found that participation of interest groups as amici curiae had modestly increased after World War II, ${ }^{17}$ but he insisted that organized interest groups "appear to play a relatively minor role in Supreme Court decision making." $\mathrm{A}$ more comprehensive study completed in 1971 found clear evidence of increasing amicus curiae participation between 1920 and 1966, though still in far fewer than half of the cases overall. ${ }^{19}$ By 1982, it was apparent that a major shift was underway. Karen O'Connor and Lee Epstein reported that for the period from 1970 to 1980, amicus participation had risen to three times the level of the World War II era. ${ }^{20}$ Most recently, Andrew Koshner has documented a continuing and steady increase in the overall percentage of cases with at least one

${ }^{16}$ Nathan Hakman, Lobbying the Supreme Court-An Appraisal of "Political Science Folklore, "35 FORDHAM L. REV. 15, 15 (1966).

${ }^{17}$ See Nathan Hakman, The Supreme Court's Political Environment: The Processing of Noncommercial Litigation, in FRONTIERS OF JUDICTAL RESEARCF 199, 209-10 (Joel B. Grossman \& Joseph Tanenhaus eds., 1969).

${ }^{18}$ Hakman, supra note 16 , at 50.

${ }^{19}$ See Puro, supra note 2, at 54-56 (examining all Supreme Court cases decided on the merits between 1920 and 1966).

${ }^{20}$ See Karen O'Connor \& Lee Epstein, Amicus Curiae Participation in U.S. Supreme Court Litigation: An Appraisal of Hakman's "Folklore," 16 LAW \& Soc. REv. 311, 317 (1981-82) (finding that while amicus briefs were filed in only $18.2 \%$ of noncommercial cases before the Supreme Court between 1941 and 1952, they were filed in 53.4\% of such cases between 1970 and 1980). 


\section{amicus brief from 1950 to $1994 .^{21}$}

Our study, which provides a complete assessment of amicus activity for nearly the entire post-War period, shows conclusively that a major reorientation in practice has taken place. Amicus participation has risen dramatically over the last fifty years. ${ }^{22}$ The point can be conveyed, as in Figure 1, by a simple examination of the number of amicus briefs filed in each of the five decades of our study. The Court received some 4907 amicus briefs in the last decade (1986-1995), as opposed to 531 briefs in the first decade (1946-1955) —an increase of more than $800 \%{ }^{23}$

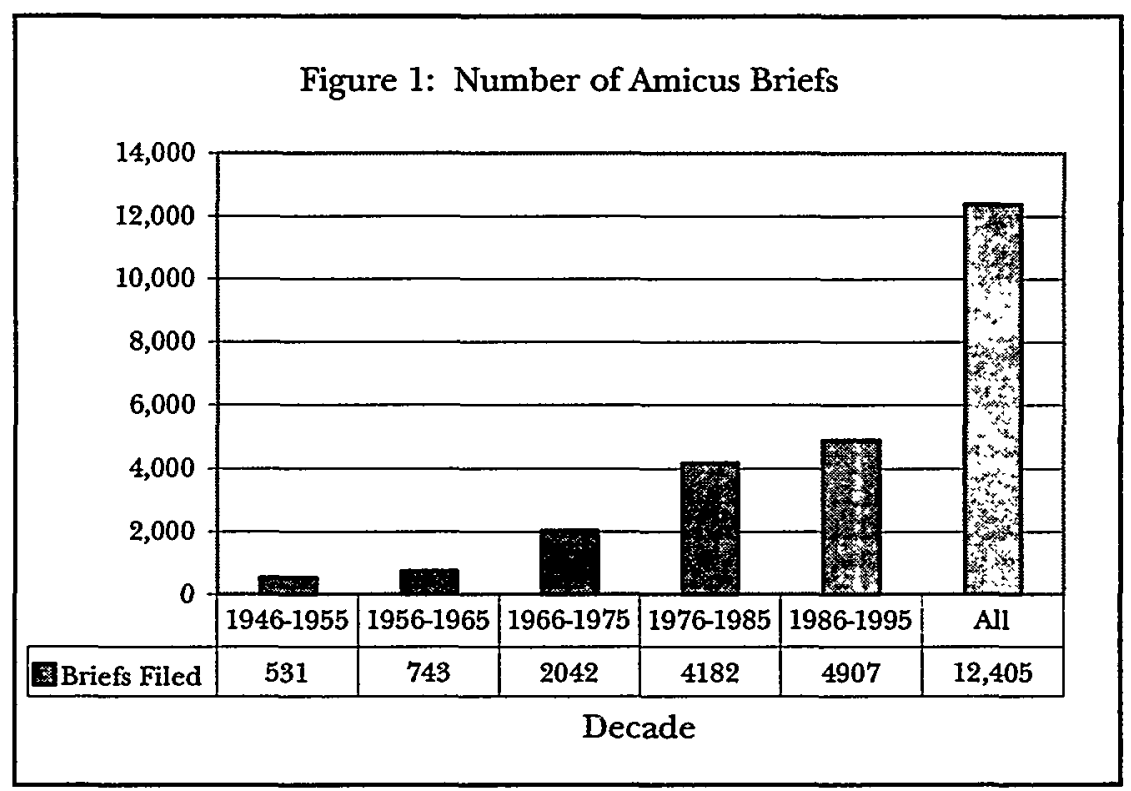

${ }^{21}$ See ANDREW JAY KOSHINER, SOLVING THE PUZZIE OF INTEREST GROUP LITIGATION 7-11 (1998) (showing an increase from under $15 \%$ of cases in 1950 to over $92 \%$ in 1994); see also LEE EPSTEIN ET AL., THE SUPREME COURT COMPENDIUM: DATA, DECISIONS \& DEVELOPMENTS 647-48 (2d ed. 1996) (reporting percent and number of Supreme Court cases with at least one amicus brief, 1953-1993).

${ }_{22}$ The Supreme Court divides its proceedings into Terms-for example, an October Term ordinarily starts the first Monday of each October, and all cases argued in the fall and the following winter and spring are decided in that October Term. For ease of exposition, throughout this Article we will simply refer to a year (e.g., 1956) when we are in fact referring to the October Term that commenced that year and ran into the next year (e.g., October Term 1956, which ran from 1956 to 1957). Our study thus begins in 1946 and ends in 1996 (at the end of October Term 1995).

${ }^{23}$ Because of the nature of the Court's decisional system (and, in particular, its occasional use of consolidated cases that may have varying numbers of amicus briefs), there may be some slight variance between the numbers in our database and the num. ber of amicus briefs actually filed in the Court. For a full explication of this point, see 
The increase in amicus briefs is equally impressive when expressed in terms of the percentage of total argued cases. Although the number of cases set by the Court for oral argument increased during the first four decades, in the most recent decade it has fallen back to a level closer to that of the 1946-1955 period. ${ }^{24}$ The percentage of argued cases with one or more amicus briefs, however, has marched ever higher throughout our study period. As shown in Figure 2, whereas one or more amicus curiae briefs were filed in $23 \%$ of argued cases in the decade from 1946 to 1955, this figure rose steadily and steeply to $85 \%$ of argued cases in the most recent decade, 1986 to $1995 .^{25}$

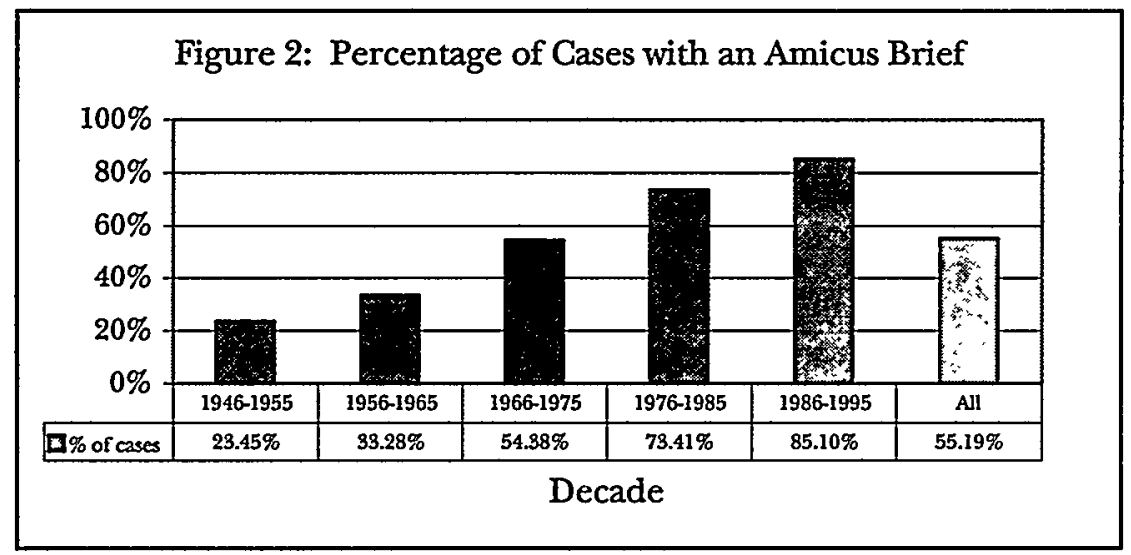

\begin{tabular}{|l|c|c|c|c|c|c|}
\hline Data Undenting Fignoe 2 & $1946-1955$ & $1956-1965$ & $1966-1975$ & $1976-1985$ & $1986-1995$ & All \\
\hline Number of Cases with Amicus Biefs & 250 & 391 & 714 & 1052 & 982 & 3399 \\
\hline Total Number of Cases & 1066 & 1175 & 1313 & 1433 & 1154 & 6141 \\
\hline
\end{tabular}

infra Appendix B at note 13.

${ }^{24}$ The number of argued cases increased in each of the first four decades (by $10.23 \%, 11.74 \%$, and $9.14 \%$ in each successive decade) and then fell by $19.47 \%$ in the fifth decade (even as the number of amicus briefs continued to rise) and wound up only $8.26 \%$ higher than in the first decade.

${ }^{25}$ The frequency of amicus participation by the four institutional litigants tracked in our study generally mirrors the frequency of participation overall. The Solicitor General, the ACLU, the AFL-CIO, and the States have participated in increasingly higher percentages of cases over the five decades in question. Specifically, in the five decades of our study (taken in chronological order), the Solicitor General filed amicus briefs in $6.38 \%, 9.28 \%, 13.40 \%, 21.49 \%$, and $28.60 \%$ of all cases (for an aggregate total throughout the five decades of $16.14 \%$ of all cases). The ACLU filed amicus briefs, by decade, in $3.47 \%, 4.60 \%, 7.84 \%, 12.35 \%$, and $16.03 \%$ of all cases (for an aggregate total of $9.05 \%$ ). The AFL-CIO participated as amicus in $2.81 \%, 2.21 \%, 4.42 \%, 5.72 \%$, and $6.24 \%$ of all cases (for an aggregate total of $4.36 \%$ ). Finally, the States filed amicus briefs in $4.13 \%, 5.11 \%, 12.64 \%, 19.47 \%$, and $29.64 \%$ of all cases (for a total of $14.51 \%)$. 
Another measure of the intensity of amicus participation is the number of amicus briefs per argued case. The mean (average) number of briefs per case has also shot up in the last fifty years. Expressed in terms of total cases, the mean has increased from about 0.50 per case to 4.23 per case over the course of the five decades. Perhaps more instructively, when expressed in terms of the cases in which one or more amicus briefs were filed, the mean number of amicus briefs per case has also multiplied, going from 2.12 in the first post-War decade to 5.00 in the most recent period. ${ }^{26}$

Arguably, the mean number of briefs per case provides a misleading picture of the intensity of amicus participation, given that (as we discuss below) a small number of cases attract unusually high numbers of amicus briefs. However, looking at the cases where there is some amicus activity, the median number of briefs jumps from one to three over the period of our study. ${ }^{27}$ Thus, not only are more cases attracting amicus filings, but it is clear that the intensity of participationwhether measured in terms of the mean or median numbers of briefs per case-is also rising.

The phenomenon of certain cases attracting extraordinarily large numbers of amicus briefs warrants special comment. The phenomenon is not entirely new; earlier landmark decisions such as Brown $v$. Board of Education, Baker v. Carr, and Furman v. Georgia also drew aboveaverage numbers of amicus filings. ${ }^{28}$ As with other aspects of Supreme Court amicus curiae practice, however, the most recent decades have seen a qualitative change in the number of cases attracting extraordinarily large numbers of amicus filings. All of the cases that have attracted twenty or more briefs have come since the twenty-fifth year of

${ }^{26}$ The mean, median, and modal number of amicus briefs per case during each decade and the mean, median, and modal number of briefs in each case with at least one amicus brief (denominated " $w / 1+^{\prime \prime}$ ) in each decade are as follows:

\begin{tabular}{|c|c|c|c|c|c|c|}
\hline & Mean & Mean w/I+ & Median & Median w/1+ & Mode & Mode $w / 1+$ \\
\hline $1946-1955$ & 0.50 & 2.12 & 0 & 1 & 0 & 1 \\
\hline 1956-1965 & 0.63 & 1.90 & 0 & 1 & 0 & 1 \\
\hline $1966-1975$ & 1.56 & 2.86 & 1 & 2 & 0 & 1 \\
\hline $1976-1985$ & 2.92 & 3.98 & 2 & 3 & 0 & 1 \\
\hline 1986-1995 & 4.23 & 5.00 & 3 & 3 & 1,2 (tie) & e) 1,2 (tie) \\
\hline All & 2.02 & 3.66 & 1 & 2 & 0 & 1 \\
\hline
\end{tabular}


our fifty-year study (i.e., since 1970). Indeed, no argued case elicited more than thirty amicus briefs until the last twenty years of our study. ${ }^{29}$

Most but not all of the thirty-four cases that have triggered twenty or more amicus briefs during the fifty-year period of our study involve controversial social and political issues such as abortion, affirmative action, free speech, church-state relations, and takings of property. ${ }^{30}$ The all-time record-setter in terms of amicus participation is Webster $v$. Reproductive Health Services, ${ }^{31}$ an abortion case which drew seventy-eight briefs-forty-six supporting the petitioner (the Attorney General of Missouri, who asked the Supreme Court to overrule its decision in Roe $v$. Wade) and thirty-two supporting the respondents (who asked that Roe be reaffirmed).$^{32}$ Other notable cases with large numbers of briefs include Regents of the University of Califormia $v$. Bakke, ${ }^{33}$ the 1978 affirmative action case, whose fifty-four briefs stood as a record until Webster, and Cruzan v. Director, Missouri Department of Health, ${ }^{34}$ where the rightto-die issue attracted thirty-nine briefs. Although falling outside the period of our study, the Court's 1997 assisted-suicide decisions continued this trend, each eliciting more than forty amicus briefs. ${ }^{35}$

The very large numbers of amicus briefs filed in a small number of controversial cases have probably done more than anything else to raise public consciousness about amicus briefs. For example, a number of commentators have associated the outpouring of amicus filings in abortion cases with the public protests and letter-writing campaigns

${ }^{29}$ The number of cases spawning 10 or more, 20 or more, and 30 or more briefs per decade is as follows:

$\begin{array}{lrrr} & 210 & 220 & 230 \\ 1946-1955 & 3 & 0 & 0 \\ 1956-1965 & 2 & 0 & 0 \\ 1966-1975 & 29 & 3 & 0 \\ 1976-1985 & 79 & 10 & 2 \\ 1986-1995 & 119 & 21 & 4 \\ \text { All } & 232 & 34 & 6\end{array}$

${ }^{30}$ The 34 cases with 20 or more amicus briefs during the 50-year period of our study and the issues raised in each case are set forth in Appendix A, infra.

492 U.S. 490 (1989).

${ }^{32}$ See Susan Behuniak-Long, Friendly-Fire: Amici Curiae and Webster v. Reproductive Health Services, 74 JUDICATURE 261, 261 (1991).

ss 438 U.S. 265 (1978).

497 U.S. 261 (1990).

${ }^{35}$ See Washington v. Glucksberg, 521 U.S. 702, 704 n.* (1997); Vacco v. Quill, 521 U.S. 793, 794 n.* (1997); see also Richard E. Coleson, The Glucksberg E Quill Amicus Curiae Briefs: Verbatim Arguments Opposing Assisted Suicide, 13 ISSUES L. \& MED. 3, 3 (1997) (reporting that the two cases occasioned a total of $60 \mathrm{briefs,} 19$ in favor of assisted suicide and 41 opposing it). 
that have been directed at the Court and others over this issue. ${ }^{36}$ As our study reveals, however, the phenomenon is by no means limited to such high-profile cases. Large numbers of amicus briefs have also been filed in cases involving copyright protection, punitive damages, and the apportionment of state taxes. ${ }^{37}$ In addition, our study clearly establishes that the overall percentage of argued cases with amicus participation has increased dramatically, as has the median number of amicus briefs in cases with some amicus participation. ${ }^{3 s}$ Thus, although amicus briefs make their most dramatic appearance in highly visible controversies, amicus participation is now well-established in all areas of Supreme Court litigation.

${ }^{36}$ See, e.g., Lee Epstein, Courts and Interest Groups, in THE AMERICAN COURTS: A CrItical ASSESSMENT 335, 349 (John B. Gates \& Charles A. Johnson eds., 1991) (linking amicus briefs with political protests and concluding that "pro-life and pro-choice forces treated the Court as if it were Congress considering a piece of legislation, not a judicial body deliberating points of law"); Stuart Taylor Jr., High Court Hears 2 Abortion Cases, N.Y. TIMES, Nov. 6, 1985, at A22 (using the large number of amicus briefs to illustrate the "elemental religious and political fervor generated by the abortion issue around the country"); Abortion Lobbying, NEWSDAY, Apr. 21, 1989, at 14 (describing ACLU-led coalition's delivering 200,000 letters to Attorney General Thornburgh in effort to persuade him to withdraw an amicus brief in an abortion case).

${ }^{37}$ See infra Appendix A. The largest number of amicus briefs in a non-headlinegrabbing case was 32, filed in Container Corp. of America v. Franchise Tax Board, 463 U.S. 159 (1983), which involved the question of the constitutionality under the Due Process and Commerce Clauses of aspects of California's corporate income tax.

${ }^{38}$ Treating each decade as a separate sample of cases, we ran one-sample t-tests of the mean number of amicus briefs filed per case in each decade. The "tightness" of the mean measured by a $95 \%$ Confidence Interval (with a test value of zero cases filed) was relatively consistent across the data; for each decade, the mean lies close to the center of the $95 \%$ Confidence Interval range of values. We infer from this result that the increase in the mean number of briefs per case is primarily a result of the trend toward increased filing activity across all cases: fewer and fewer cases have no amicus briefs. However, the impact of cases with large numbers of amicus briefs in recent decades is noticeable, as evidenced by the increase in the standard deviation of the mean in recent decades. This suggests that not only is the mean number of briefs filed per case rising, but the number of cases with especially large numbers of amicus briefs is increasing in frequency as well, increasing the standard deviation around the mean number of briefs per case.

$\begin{array}{lccc} & \text { Mean } & \text { Standard Deviation } & \text { 95\% Confidence Interval of the Mean } \\ 1946-1955 & 0.50 & 1.43 & 0.41-0.58 \\ 1956-1965 & 0.63 & 1.29 & 0.56-0.71 \\ 1966-1975 & 1.56 & 2.62 & 1.41-1.70 \\ 1976-1985 & 2.92 & 3.94 & 2.71-3.12 \\ 1986-1995 & 4.23 & 5.07 & 3.96-4.54 \\ \text { All } & 2.02 & 3.54 & 1.93-2.11\end{array}$




\section{B. Citation and Quotation of Amicus Briefs, 1946-1995}

Clearly, amici curiae are playing an increasingly active role in supplying input to the Court's decision-making process. What can be said about the impact of these briefs on the Court's output? The only publicly visible manifestation of the impact of amici is the frequency with which their briefs are cited or quoted in the opinions of the Justices. A mere passing familiarity with the Court's decisions reveals that amicus briefs are often referred to by the Justices. ${ }^{39}$ Less impressionistically, one study examined all Supreme Court cases with amicus participation from 1969 to 1981 and found that $18 \%$ included one or more references to an amicus brief. ${ }^{40}$

To provide a more authoritative picture of the Court's references to amicus briefs, we undertook a computer-aided review of all the cases in our database to determine the frequency of citation and quotation of amicus briefs from 1946 to 1995 . Specifically, we examined every reference by the Court to an amicus in the case before the Court, whether the reference was in a majority, plurality, concurring, or dissenting opinion. ${ }^{41}$

There is no question but that the total number of references to amici is substantial, and that the frequency of such references has been increasing over time. We found a total of 936 decisions in which there were one or more references to an amicus in the case. This represents just under $28 \%$ of all decisions in which one or more amicus briefs were filed. Moreover, as Figure 3 reflects, the likelihood of a Supreme Court decision's referring to an amicus in the case increases over the five decades of our study, beginning with close to $18 \%$ of the cases with amicus filers decided between 1946 and 1955 and ending with just under $37 \%$ of the cases with amicus filers between 1986 and $1995 .^{42}$

${ }^{39}$ See, e.g., cases cited supra note 5.

${ }^{40}$ See Karen O'Connor \& Lee Epstein, Court Rules and Workload: A Case Study of Rules Governing Amicus Curiae Participation, 8 JUST. SYs. J. 35, 42 (1983).

11 For a description of our methodology in undertaking the citation study and of how we defined "citation," see infra Appendix B.2.

42 One scholar has offered what appears to be a much higher estimate of the frequency of citation of amicus briefs, reporting that "the proportion of written opinions citing at least one brief" was .417 for Warren Court Justices, .656 for Burger Court Justices, and .676 for Rehnquist Court Justices. See Lee Epstein, Interest Group Litigation During the Rehnquist Court Era, 9 J.L. \& POL. 639, 650 (1993). It appears that these estimates were derived by counting the total number of citations of amicus briefs by each Justice and dividing by the number of opinions written by each Justice. See id at 651 tbl.2. As Epstein explains, see id. at 651 n.62, this does not account for the fact that Jus- 


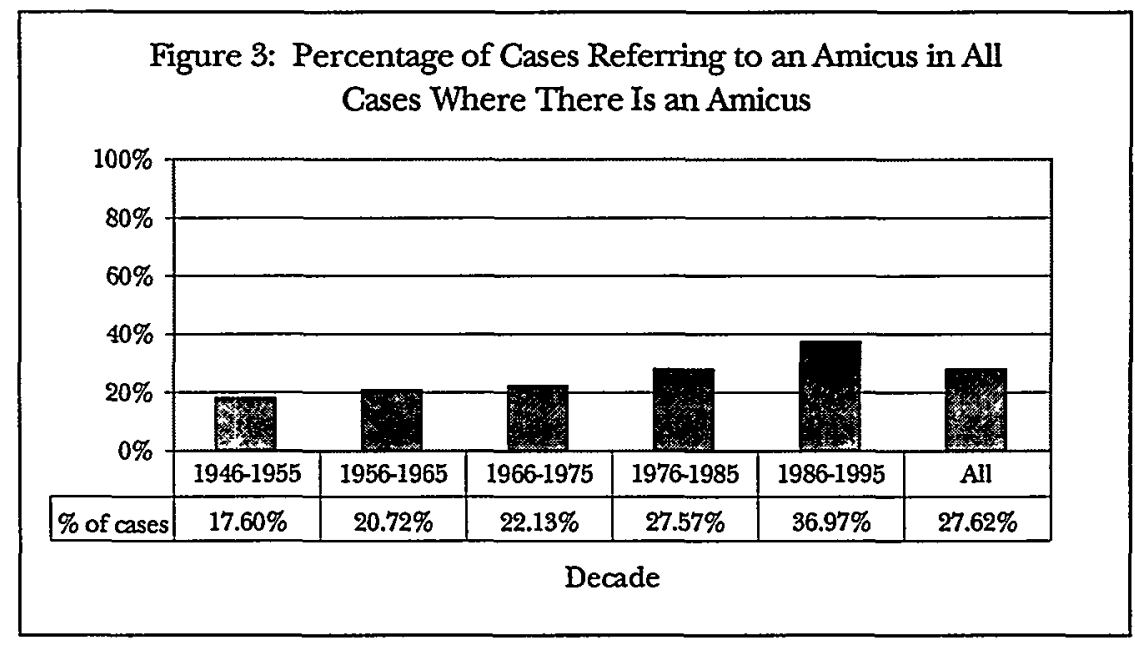

Data Underting Figure 3

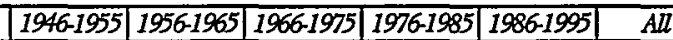
\begin{tabular}{|l|l}
\hline Number of Cases Referring to an Amicus & 44
\end{tabular} Total Number of Cases with an Amicus

250

81

391

\begin{tabular}{l|r}
158 & 290 \\
\hline 714 & 1052 \\
\hline
\end{tabular}

363

We also catalogued the extent to which the Court over the past fifty years has actually quoted the arguments of amici. The incidence of quotations could yield a truer approximation of the extent to which the Court has actually relied on amicus arguments, particularly when assessed on a relative basis over time. ${ }^{43}$ We found a total of 316 decisions in which one or more amicus arguments were quoted by the Court. As revealed in Figure 4, the incidence of quoted arguments in cases with amicus filers also increases over the five decades. Particularly noteworthy is the fact that the rate of such cases with quoted amici jumps in the most recent decade to over $15 \%$, which is more than double the rate of the first three decades and almost double the rate of the fourth.

tices may cite more than one amicus brief in a given opinion-as in fact they often do. We are confident that our numbers present an accurate picture of the frequency of citation of amicus briefs in the Court's decisions.

${ }^{43}$ As noted below, see infra text accompanying note 44, the Court's practice of occasionally referring to amici generically, especially in recent years, makes it difficult to be precise about the frequency of citations of amicus briefs relative to the number of amicus briefs. 
Figure 4: Percentage of Cases Quoting an Amicus in All Cases Where There Is an Amicus

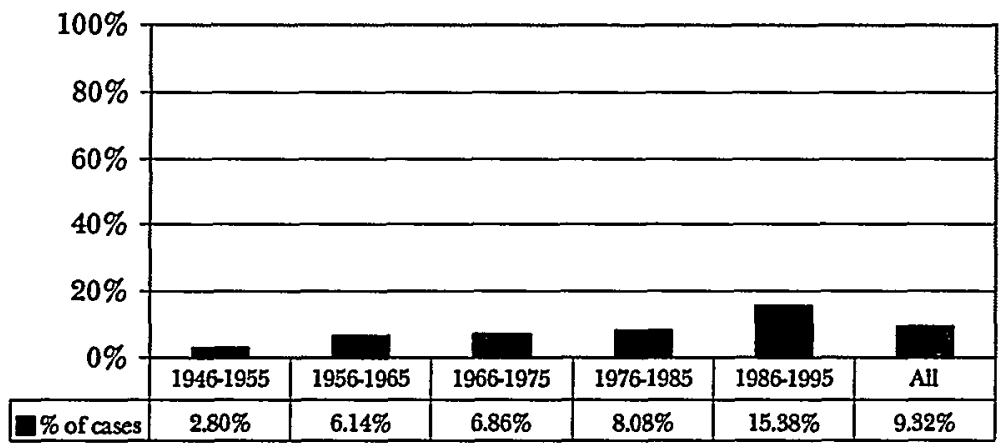

Decade

\begin{tabular}{|l|c|c|c|c|c|c|}
\hline Data Underlying Figure 4 & $1946-1955$ & $1956-1965$ & $1966-1975$ & $1976-1985$ & $1986-1995$ & All \\
\hline Cases Quoting Amicus & 7 & 24 & 49 & 85 & 151 & 316 \\
\hline Total Cases with Amicus & 250 & 391 & 714 & 1052 & 982 & 3389 \\
\hline
\end{tabular}

Arguably a more revealing measure of whether the Court is referring to amicus briefs more frequently is not the rate of citations or quotations of amicus briefs per case, but rather the rate of citations or quotations per amicus brief filed. If the total number of citations and quotations is rising (as it is), but the number of amicus briefs is also rising (as it is), then the actual chance of any given brief's being cited or quoted may be decreasing. Unfortunately, because the Court often refers to amici as a group (as in the increasingly popular opinionwriter's phrase, "petitioner and its amici argue ..."), we cannot calculate precisely the number of citations per brief filed. ${ }^{45}$ Nevertheless, we can calculate other ratios that should roughly mirror the changes in the rate of references per brief.

First, because there is no ambiguity about when the Court actually quotes from a specific amicus, we can calculate the ratio of quoted amici to the total number of amicus briefs filed. When the data are

${ }^{44}$ See infra Appendix B at note 29 and accompanying text (noting that by the 1980s numerous opinions used this and similar formulations).

${ }^{45}$ Because of the nature of the Court's writing style, our citation study tracked whether or not an opinion cited 0,1 , or more than 1 amicus brief, and did not measure the precise number of briefs cited if more than 1 brief was cited. See generally infra Appendix B.2. Thus, we cannot calculate the incidence of citations per amicus brief filed (i.e., the odds of any single amicus brief's being referred to by the Court). 
arranged by decade, we find this ratio fluctuates around an average of about $3 \%$, with the first decade showing a lower frequency of quoted amici than the middle decades, the most recent decade showing a slightly higher frequency of quoted amici than previous decades, and some variation in between. Although no decisive trend emerges, this pattern certainly does not support the proposition that the rate of references is going down as the number of amicus filings goes up. ${ }^{46}$

Second, because there is also relatively little ambiguity about when the Court refers to an amicus brief of a specific institutional litigant, we can compute the trend line with respect to the rate of references per amicus brief for three of the institutional litigants tracked in our study-the Solicitor General, the ACLU, and the AFL-CIO. ${ }^{47}$ The king of the citation-frequency hill is the Solicitor General, and this is increasingly true. The Court referred to the Solicitor General as amicus in 402 cases during the fifty years of our study, which works out to just over $40 \%$ of the cases where the Solicitor General filed a brief. ${ }^{48}$ Significantly, the frequency of the Court's citation of the Solicitor General as amicus rises each decade, roughly doubling between the first decade of our study and the most recent decade. ${ }^{49}$ This strongly suggests that the Court has come to rely more heavily on the Solicitor General's amicus filings in the last fifty years, at least in the writing of opinions.

In contrast, when we look to the two other institutional litigants, we find no such pattern of increased incidence of citation. Here, the number of briefs is sufficiently small that one should exercise caution in drawing any firm conclusions. ${ }^{50}$ Nevertheless, we find that the

${ }^{46}$ The odds of a particular amicus brief's being quoted by the Court were, by decade, $1.32 \%$ in 1946-1955 (7 of 531 amicus briefs were quoted), 3.50\% in 1956-1965 (26 of 743 ), $2.69 \%$ in 1966-1975 (55 of 2042), $2.37 \%$ in 1976-1985 (99 of 4182 ), and $3.89 \%$ in 1986-1995 (191 of 4907), and, across the 50-year period of our study, $3.05 \%$ ( 378 of 12,405).

${ }^{47}$ Comparative numbers for the States are not as meaningful, since multiple States often file amicus briefs in individual cases.

${ }^{48}$ The Solicitor General filed an amicus brief in 991 cases between 1946 and 1995 .

49 The details are as follows: in 1946-1955, the Solicitor General was cited in $26.47 \%$ of the cases in which he filed an amicus brief ( 18 of 68 cases); in 1956-1965, $30.28 \%$ (33 of 109 ); in 1966-1975, 36.93\% (65 of 176); in 1976-1985, $42.53 \%$ (131 of 308 ); and in $1986-1995,46.97 \%$ ( 155 of 330 ).

${ }^{50}$ We do not provide standard tests of statistical significance for the number of quoted briefs per case and other subsets of our database. As explained in more detail in Appendix C, this is because our subset populations represent all cases that fit a specific category of analysis, derived from the total population of cases. Since the database contains all cases where an amicus brief was filed, there is no need to draw upon sampling methodologies in this study. Thus, all of the numbers reported in this Part 
ACLU was referred to as amicus only twenty-four times overall or in $4.32 \%$ of the 556 cases in which it filed an amicus brief. This rate varied somewhat over the five decades but never exceeded $8.11 \% .^{51}$ The AFL-CIO fared slightly better, being cited twenty-eight times, or in $10.45 \%$ of the 268 cases where it appeared as amicus. After a sharp increase during the Warren Court decade of $1956-1965,{ }^{52}$ this rate also has remained more or less steady over the last thirty years. ${ }^{53}$

In sum, there is no evidence that the rise in the frequency of citations and quotations of amicus briefs per case masks a decrease in the frequency per brief filed. To the contrary, there is reason to believe that the rate of citations and quotations per brief is more or less keeping pace with the increase in filings. The one notable exception to the pattern is the Solicitor General, whose office has seen its amicus briefs cited with significantly increased frequency during the period of our study, suggesting (not for the last time, as we shall see) that the Solicitor General's office is in a class by itself in terms of its influence as an amicus filer.

\section{THE OPEN DOOR POLICY TOWARD AMICUS BRIEFS}

In seeking to explain the changing role of the amicus curiae in the last fifty years, it is important to consider briefly the Court's role as gatekeeper in permitting amicus participation. In this Part, we review the Court's rules and practices regarding amicus curiae participation and ask whether changes in those rules and practices may have played a role in the surge of amicus filings we have seen in recent decades.

The Court's formal rules regarding amicus participation have in broad outline remained essentially unchanged since they were first promulgated in $1939 .^{54}$ Those rules today provide that governmental

and in Part V are statistically significant in the technical sense that they represent the total population of cases of interest. Still, it is appropriate to exercise caution in drawing conclusions from subsets of cases where the population size is quite small. See infra Appendix $\mathrm{C}$ (discussing the statistical analysis used in the study).

${ }_{51}$ The specific numbers by decade for the ACLU are $8.11 \%$ for 1946-1955 (3 of 37 ACLU briefs were referred to), $5.56 \%$ for $1956-1965$ (3 of 54), $5.83 \%$ for $1966-1975$ (6 of 103), 1.69\% for 1976-1985 ( 3 of 177 ), and $4.86 \%$ for $1986-1995$ (9 of 185).

${ }^{52}$ Note, however, that the number of cases with citations of the AFL-CIO's amici briefs was only five in that decade. See infra note 53.

${ }^{53}$ Specifically, the numbers for the AFL-CIO by decade are $6.67 \%$ for $1946-1955$ (2 of 30 briefs were referred to), 19.23\% for 1956-1965 ( 5 of 26 ), 10.34\% for 1966-1975 (6 of 58 ), $9.76 \%$ for $1976-1985$ ( 8 of 82 ), and $9.72 \%$ for $1986-1995$ (7 of 72).

${ }^{54}$ The original rule consisted of one paragraph within the rule governing the filing of briefs. See SUP. CT. R. 27.9, 306 U.S. 671, 708-09 (1939). In 1949, the Court added four more paragraphs, spelling out, inter alia, the procedure for motions for leave to 
representatives-such as the Solicitor General or a state attorney general-may file an amicus curiae brief in any case. ${ }^{55}$ Nongovernmental entities may file an amicus curiae brief in any case if they obtain the consent of all parties. ${ }^{56}$ If a party refuses to consent to an amicus filing, then a would-be amicus curiae may file a motion with the Court seeking leave to file a brief..$^{57}$ The full Court will then either grant the motion, permitting the would-be amicus to file over the party's objection, or deny the motion.

The biggest change in the last fifty years has occurred not in the Court's formal rules, but in the manner in which they are implemented. The Court's current practice in argued cases is to grant nearly all motions for leave to file as amicus curiae when consent is denied by a party. ${ }^{58}$ Because the Court in recent years has routinely granted such motions, parties that are represented by experienced lawyers will in most cases consent to such filings, if only to avoid burdening the Court with the need to rule on the motion. The effect of the Court's liberality in ruling on motions for leave to file, therefore, is to permit essentially unlimited filings of amicus briefs in argued cases.

file amicus briefs. See Amendment of Rules, 338 U.S. 959, 959-60 (1949). When the Court promulgated new rules in 1967, amicus briefs received their own rule for the first time, but the content of the rule was unchanged. See SUP. CT. R. 42, 388 U.S. 931, 973-75 (1967). With another new set of rules in 1990, the rule was renumbered and a new subsection was added at the beginning, admonishing that amicus briefs failing to bring new relevant matter to the attention of the Court are "not favored." SuP. Cr. R. 37.1, 493 U.S. 1099, 1145-47 (1989); see infra text accompanying note 113 (quoting this provision). In 1997, the rule was amended again to require disclosure of party involvement in the drafting or funding of amicus briefs. See SUP. CT. R. 37.6; see infra text accompanying note 73 (discussing possible rationales behind the new rules). (The Supreme Court Rules currently in force are available at 519 U.S. 1159 (1997).)

${ }_{55}$ See SUP. CT. R. 37.4.

${ }^{56}$ See SuP. CT. R. 37.3(a).

57 See SUP. GT. R. 37.3(b).

${ }^{5 s}$ See Epstein, supra note 42, at 650 (reporting that the Rehnquist Court denied only one out of 115 motions for leave to file in 1990). The rules state that a motion for leave to file as amicus curiae "is not favored" at the certiorari stage during which the Court decides whether it will consider the case on the merits. SuP. CT. R. 37.2(b). Nonetheless, our understanding is that even here such motions are routinely granted. See, e.g., Ford Motor Co. v. Fulkerson, 517 U.S. 1229 (1996) (granting motion for leave to file amicus brief and denying petition for certiorari); Ford Motor Co. v.Sperau, 517 U.S. 1217 (1996) (granting motion for leave to file amicus brief and granting petition for certiorari); Mock v. Pennsylvania Dep't of Envtl. Resources, 517 U.S. 1216 (1996) (granting motions for leave to file amicus briefs and denying petition for certiorari). 
The Court has not always followed this "open door" policy. ${ }^{59}$ In the late 1940s and early 1950s, large numbers of amicus briefs were submitted in several controversial cases involving government investigation of Communist Party activities, including the prosecution of the "Hollywood Ten" for failing to testify before the House Un-American Activities Committee ${ }^{60}$ and the espionage convictions of Ethyl and Julius Rosenberg. ${ }^{61} \quad$ Some Justices were reportedly put off by the "propagandistic" tone of these filings, and the Court sought to curtail the filing of amicus curiae briefs. ${ }^{62}$ In terms of formal action, the Court amended its rules to emphasize that the consent of all parties was required for a nongovernmental entity to file an amicus brief, and spelled out in detail the procedure for filing a motion with the Court for leave to file if consent was denied. ${ }^{63}$ More importantly, the Court adopted the unwritten policy of denying virtually all motions for leave to file as amicus curiae when consent was denied. ${ }^{64}$ The Solicitor General viewed this policy as a signal from the Court that it wanted the government to refuse to consent to amicus filings in cases in which the United States was a party, and the Solicitor General obliged. ${ }^{65}$ The net effect of these coordinated efforts was that the number of amicus filings in argued cases declined around 1949 and remained at a relatively depressed level throughout the $1950 \mathrm{~s}$.

Several years after this clamp-down on amicus filings, some of the

59 See generally O'Connor \& Epstein, supra note 40, at 36-39 (recounting the history of the Court's rules regarding amicus curiae submissions).

${ }^{60}$ See Lawson v. United States, I76 F.2d 49 (D.C. Cir. 1949), cert. denied, 339 U.S. 934 (1950); Fowler V. Harper \& Edwin D. Etherington, Lobbyists Before the Couth, $101 \mathrm{U}$. PA. L. Rev. 1172, 1173 (1953) (discussing Lawson case); Krislov, supra note 1, at 710 (same).

${ }^{61}$ See Harper \& Etherington, supra note 60, at 1173 n.4 (discussing the amicus activity in the Rosenberg case); Krislov, supra note 1, at 710 (same).

${ }^{62}$ See Krislov, supra note 1, at 711 (recounting Justice Black's critical comments regarding attempts through amicus briefs, telegrams, and letters to pressure the Court to reach particular conclusions); see also Puro, supra note 2, at 39-40 (describing the Court's frustration with briefs offered at the certiorari stage because they were lacking in "legal merit" and "[un]related to the points of law in the case"); Harper \&Etherington, supra note 60, at 1173; Comment, The Amicus Curiae, 55 Nw. U. L. REV. 469, 474 (1960).

${ }^{63}$ See Amendment of Rules, 338 U.S. 959 (1949). Note that these amendments did not change prior practice, but simply made that practice explicit.

${ }_{61}$ See Harper \& Etherington, supra note 60, at 1173-76; Krislov, supra note 1, at 71314; O'Connor \& Epstein, supra note 40, at 37-38; Puro, supra note 2, at 41.

${ }_{65}$ See Krislov, supra note 1, at 714 (describing the Solicitor General's change from automatically granting consent to amici to automatically withholding it). 
Justices began to have a change of heart. In published opinions, Justices Frankfurter and Black each indicated unhappiness with the Solicitor General's restrictive policy of denying consent in virtually all cases. $^{66}$ In 1957, the Solicitor General responded by issuing a "policy statement" softening the government's attitude toward consent to amicus participation. ${ }^{67}$ By 1959 , it was clear that when consent to file was refused, the Court was granting far more motions for leave to file than it was denying. ${ }^{69}$ As shown below in Figure 5, the number of amicus briefs soon started to increase. After the early 1960s, the attitude of the Court toward amicus filings in argued cases gradually became one of laissez-faire. Two studies of the Court's rulings on motions for leave to file published in the mid-1980s found that the Court rarely granted fewer than $85 \%$ of these motions between 1959 and 1981 , and in the later years it was granting an even higher percentage. ${ }^{69}$ There is no indication that this practice has changed. Today, it can truly be said, the Supreme Court's policy "is to allow essentially unlimited amicus participation. ${ }^{70}$

The Court's open door policy toward amicus briefs undoubtedly provides a part of the explanation for the rising tide of such briefs in the last half-century. Whatever the benefits of filing an amicus brief

${ }^{66}$ See On Lee v. United States, 343 U.S. 924, 924 (1952) (memorandum of Frankfurter, J.); id. (statement of Black, J.); United States v. Louknit Mfg. Co., 342 U.S. 915, 915 (1952) (statement of Frankfurter, J.); Order Adopting Revised Rules of the Supreme Court, 346 U.S. 945, 947 (1954) (statement of Black, J.). Although both Justices chastised the Solicitor General, they did so for different reasons. Frankfurter did not question the Court's policy of vigorously screening amicus briefs but objected to the Solicitor General's practice of automatically refusing consent to amicus filings, on the ground that this thrust the entire burden of screening onto the Court. Black, in contrast, objected to the Court's underlying policy of discouraging amicus briefs, not to the manner in which this policy was implemented. This underlying disagreement about the merits of the restrictive policy may be the reason why the Solicitor General did not immediately change his policy.

${ }^{67}$ See Krislov, supra note 1, at 715 (describing the Solicitor General's new, i.e., post1957 , intermediate standard governing when it would grant and when it would withhold its consent from would-be amici).

${ }^{6 s}$ See id. at $716 \mathrm{n} .119$ tbl. (showing that 1959 marked a clear change from the previous pattern of denying motions).

${ }^{69}$ See Robert C. Bradley \& Paul Gardner, Underdogs, Upperdogs and the Use of the Amicus Brief: Trends and Explanations, 10 JUSTICE SYS. J. 78, 90-91 (1985) (presenting data showing the high percentage of amicus requests granted by the Court from 1959 to 1980); O'Connor \& Epstein, supra note 40, at 40-41 (presenting similar data for 1969 to 1981); see also Epstein, supra note 42, at 650 (presenting data for 1990).

${ }^{70}$ Gregory A. Caldeira \& John R. Wright, Amici Curiae Before the Supreme Court: Who Participates, When, and How Much?, 52 J. POL. 782, 784 (1990). 
may be-whether they consist of influencing the Court's decisions, being cited by the Court, or just assuring the members of an organization that its leaders are on the watch-those benefits are more readily obtained in a regime where every brief is automatically accepted. Under a regime with a significant risk of rejection, in contrast, the benefits would have to be discounted by the probability of rejection and the costs of litigating to obtain permission to file. The open door policy inaugurated after around 1960 thus had the effect of increasing the benefits of seeking to file amicus briefs relative to the costswhich one would expect to lead to an increase in filing activity.

The open door policy, however, cannot supply the whole explanation for the rising tide of amicus activity. This is because the Court's policies remained essentially unchanged over the next thirty-five years. If the open door policy initiated in the early 1960s were the only factor at work, one would expect to see an increase in filing in the 1960s followed by a levelling off thereafter. Yet, as shown in Figure 5, when we plot the expected number of amicus briefs after 1970 based on the rate of filings from 1960 through 1969, we see a much lower projected number of briefs than were actually filed during the latter half of our study. Some of the later increase may be due to perceptual lag among practicing lawyers, as the Court's open door policy gradually became more firmly entrenched and hence more visible to lawyers. Yet it seems obvious that some additional factor or factors must also be influencing groups to intensify their efforts in filing amicus briefs. ${ }^{71}$

${ }^{71}$ We return to the question of what factors might explain the increase in amicus activity in Part VI.

The decline in the number of amicus briefs filed during the last six years, as shown in Figure 5, is entirely due to a decline in the number of argued cases during these years, rather than to a falloff in the rate of filings per case. The following are the numbers of argued cases and the mean number of amicus briefs per argued case during the last decade (1986-1995) of our study:

$\begin{array}{llrr}1986 & 153 \text { cases (3.30 mean) } & 1991 & 108 \text { cases (5.02 mean) } \\ 1987 & 145 \text { cases (3.59 mean) } & 1992 & 109 . \text { cases (4.28 mean) } \\ 1988 & 145 \text { cases (4.32 mean) } & 1993 & 90 \text { cases (4.84 mean) } \\ 1989 & 131 \text { cases (4.39 mean) } & 1994 & 83 \text { cases (5.07 mean) } \\ 1990 & 114 \text { cases (3.50 mean) } & 1995 & 76 \text { cases (5.46 mean) }\end{array}$




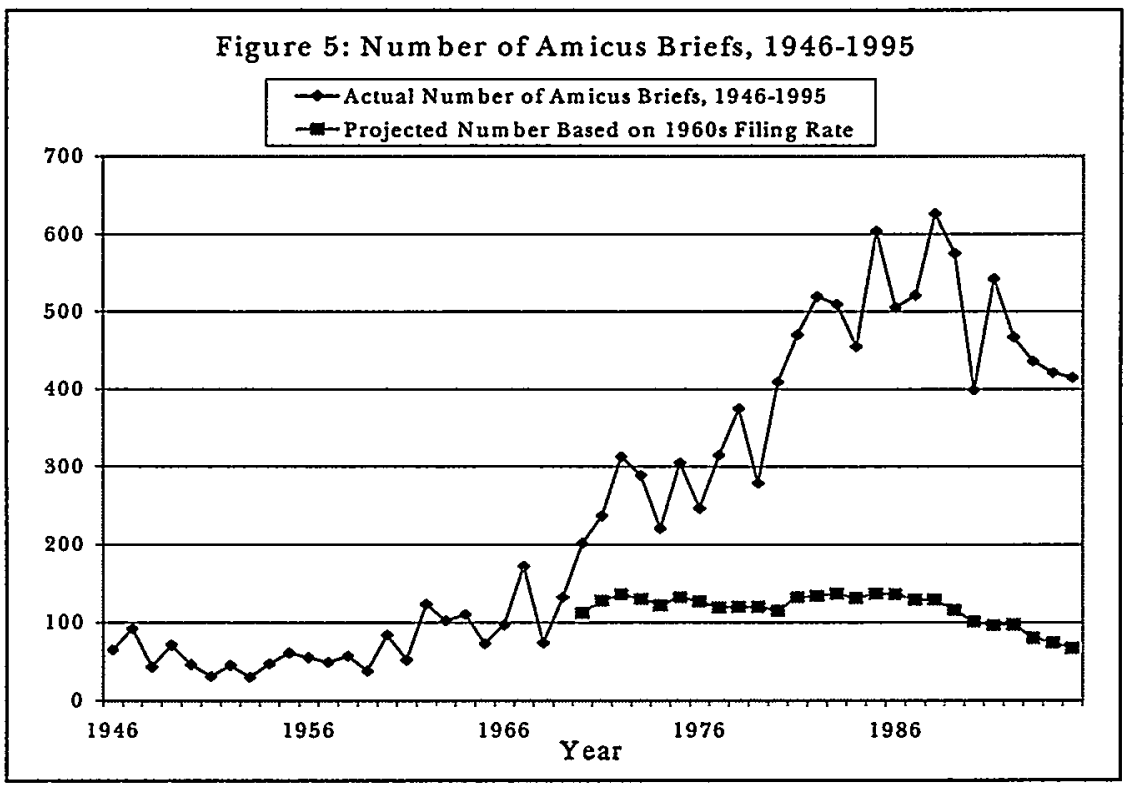

More recently, there has been a modification in the Court's rules regarding amicus curiae participation that may betoken a further change in the Court's attitude toward amicus briefs. The Court in 1997 adopted what is probably the most important amendment to its formal rules regarding amicus participation since they were first promulgated in 1939. The new Rule 37.6 requires the disclosure of certain relationships between the parties to the case and any person or entity that files an amicus brief. Specifically, the amended rule now requires that each amicus brief disclose in the first footnote on the first page of text "whether counsel for a party authored the brief in whole or in part," as well as the identity of "every person or entity, other than the amicus curiae, its members or its counsel, who made a monetary contribution to the preparation or submission of the brief. $^{72}$

The Court provided no rationale for these new disclosure requirements. The changes could mean simply that the Justices want to know if an amicus brief is written or financed by one of the parties so that they can more appropriately evaluate the contents of the brief for possible bias. ${ }^{73}$ Alternatively, the changes could reflect a perception

${ }^{72}$ SUP. CT. R. 37.6.

${ }^{73}$ Cf. Michael Rustad \& Thomas Koenig, The Supreme Court and Junk Social Science: Selective Distortion in Amicus Briefs, 72 N.C. L. REv. 91, 157-58 (1993) (advocating ex- 
by the Justices that some parties are funding or ghost-writing amicus briefs to get around the page limits that apply to the parties' briefs on the merits. Or, the amendments could reflect a growing concern on the part of the Justices that amicus filings are being manipulated in order to create an impression of widespread political support for a particular position. Thus, although the recent rule change indicates that there is some unease within the Court about the phenomenon of proliferating amicus briefs, the Court's response is consistent with a variety of different assessments of the influence that amicus briefs have on the Court.

The long term implications of the Court's new disclosure rules are unclear. Whatever concerns underlie the requirement of a disclosure of interesi or participation on the part of the parties with respect to the filing of amicus briefs, the Court has not yet changed its basic open door policy towards amicus filings.

\section{PREVIOUS STUDIES OF THE INFLUENCE OF AMICUS BRIEFS ON SUPREME COURT OUTCOMES}

By far the most important question about amicus briefs is not whether they are easy to file, or whether, if filed, they are likely to be cited or quoted. Rather, it is whether such briefs have any influence on the decisions reached by the Court. If amicus briefs have a demonstrable impact on the supported party's chances of prevailing in the Court, or on the Court's rationale for its judgment, then this would readily explain the high rate of amicus filings we have seen in recent decades. On the other hand, if amicus briefs have no impact on the Court's decision-making process, then the tidal wave of amicus briefs becomes harder to explain. ${ }^{74}$ There have been a number of

panded disclosure requirements as a way of deterring the submission of biased social science data to the Court).

${ }^{74}$ Amicus briefs can have an impact on the Court's decision-making process either by influencing the outcomes reached by the Court or by influencing the rationales used by the Court in justifying those outcomes. We have no doubt that amicus briefs have had an impact on the rationales employed by the Court. To take but one example, the Court's decision in Miranda v. Arizona, 384 U.S. 436 (1966), requiring that police give suspects defined warnings before the suspects may be subjected to custodial interrogation, does not adopt the decisional rule urged by the ACLU in its amicus brief in that case. (The ACLU urged that all custodial interrogation without counsel designed to elicit a confession be deemed unconstitutional.) But the majority opinion of Chief Justice Warren draws extensively from the argument and authorities set forth in the ACLU's brief. Compare Miranda, 384 U.S. at 448-55, 457-58 n.26, with Brief for the American Civil Liberties Union, Amicus Curiae, at 13-20, 43-67, Miranda (No. 759). Given the quantitative nature of the data we draw upon in this Article, however, we 
studies by legal scholars and political scientists over the last thirty years that shed light on the phenomenon of the amicus curiae brief. ${ }^{75}$ Most of these studies describe the role of amicus briefs in particular cases or in the resolution of particular issues. For example, they examine the strategic considerations underlying the filing of amicus briefs in the Court's decisions invalidating racial covenants, ${ }^{76}$ expanding the constitutional rights of women, ${ }^{77}$ addressing the constitutionality of affirmative action, ${ }^{78}$ and in numerous other areas. ${ }^{79}$ These studies are valuable, and suggest that groups seeking social change through litigation assume that amicus support can in some circumstances influence the Court's adoption of a particular position on a critical issue or can at least frame the debate.

Though illuminating, only rarely do these case studies address the question of whether amicus briefs have an impact on the Court, even in specific areas. ${ }^{80}$ Furthermore, even in these areas, the exact role of

have not been able to investigate in any systematic fashion the impact of amicus briefs on the rationales adopted by the Court, except insofar as we have recorded the frequency with which amicus briefs are cited or quoted by the Court. See supra Part I.B.

${ }^{75}$ In addition to the case studies discussed immediately below, scholars have explored the history of the amicus brief and its evolution over time, see, e.g., Krislov, supra note 1, at 694-704 (describing a basic shift from neutrality to partisanship), and have examined the factors that influence the decision to file an amicus brief and the Court's decision whether to permit such filings. See, e.g., Bradley \& Gardner, supra note 69, at 81-84 (exploring the motivations of amicus filers).

${ }^{76}$ See Clement E. Vose, Caucastans OnLY: The Supreme Court, the NAACP, AND THE RESTRICTIVE COVENANI CASES 163-76, 193-99 (1959) (describing the strategies that guided amici in composing their briefs).

77 See KaREN O'CONNOR, WOMEN's ORganIZATIONS' USE OF THE COURTS 100-23 (1980) (describing the activities of various women's groups that often file amicus briefs); Tracey E. George \& Lee Epstein, Women's Rights Litigation in the 1980s: More of the Same?, 74 JUDICATURE 314 (1991) (documenting the role of amicus filings by women's groups and the ACLU in seeking to convince the Rehnquist Court to maintain a relatively liberal policy in sex discrimination cases).

${ }^{78}$ See TIMOTHYJ. O'NEIII, BAKKE \& THE POLITICS OF EQUALITY: FRIENDS AND FOES IN THE GLASSROOM OF LITIGATION 165-67 (1985) (assessing the relative influence on the Court of the briefs filed in the Bakke case).

79 See, e.g., STEPHEN L. WASBY, RACE REIATIONS IN AN AGE OF COMPLEXITY 219-35 (1995) (discussing the role of amicus briefs in civil rights cases); John Howard, Retaliation, Reinstatement, and Friends of the Court: Amicus Participation in Brock v. Roadway Express, Inc., 31 How. L.J. 241 (1988) (analyzing the role of amici in a leading due process case).

${ }^{80}$ For examples of studies that do address the influence of amicus briefs in specific areas, see SUSAN E. LAWRENCE, THE POOR IN COURT 102-03 (1990) (finding that legal services providers fared less well in the Supreme Court when supported by amici); Stephen Calkins, Supreme Court Antitrust 1991-92: The Revenge of the Amici, 61 ANTITRUST L.J. 269 (1993) (providing detailed analysis of the impact of amicus briefs on the Court's antitrust decisions in a recent Term); Andrew P. Morriss, Private Amici Curiae and the Supreme Court's 1997-1998 Term Employment Law Jurisprudence, 7 WM. \& MARY 
the amici is often open to interpretation. Clearly, more extensive empirical data about the relationship between amicus curiae filings and Supreme Court outcomes are needed. ${ }^{81}$ Unfortunately, only a handful of studies have attempted to use quantitative data to assess the relationship between the filing of amicus curiae briefs and the outcomes reached by the Court ${ }^{82}$ Moreover, the studies that do exist reach strikingly inconsistent conclusions about whether such briefs have an effect on the Court.

The first empirical survey of the influence of amicus briefs on Supreme Court decision making was undertaken in a doctoral dissertation by Steven Puro completed in $1971 .^{83}$ Puro's study contains much valuable information. His data set consisted of all amicus briefs filed in reported decisions of the Supreme Court from the 1920 Term to the 1966 Term. In order to provide some basis for comparing the role of amicus briefs over time and across different filing entities, Puro computed what he called the "success rate" of various amicus filers. This was a kind of amicus curiae batting average-the number of cases in which an entity files an amicus brief supporting the prevailing party divided by the total number of amicus filings by that entity. ${ }^{84}$

Overall, Puro found that amicus filers had a success rate of .550 - that is, they filed briefs supporting the winning side $55 \%$ of the

BILL RTS. J. 823 (1999) (analyzing positions of amici in three recent Title VII cases and assessing their influence on the Court); Leo Pfeffer, Amici in Clurch-State Litigation, 44 LAW \& CONTEMP. ProBs., Spring 1981, at 83 (discussing the role that amicus briefs played in two church-state decisions).

11 There are good empirical studies of the relationship between amicus briefs at the certiorari stage and the likelihood that the Court will grant certiorari. See, e.g., H.W. PERRY, JR, DECIDING to DECIDE: AGENDA SETtING IN THE UNITED STATES SUPREME COURT 135-39 (1991) (finding that the presence of amicus briefs supporting petitioner at the certiorari stage makes the granting of certiorari more likely); Gregory A. Caldeira \& John R. Wright, Organized Interests and Agenda Setting in the U.S. Supreme Court, 82 AM. POL. SCT. REv. 1109, 1119 (1988) (concluding that "justices pay close attention to the demands of outside parties when making certiorari decisions").

${ }^{82}$ One reason for the dearth of such studies may be that the Supreme Court Database, which is the foundation on which most empirical studies of Supreme Court decision making rest, does not include information on the number of amicus briefs filed for petitioner and respondent. See INTER-UNIV. CONSORTIUM FOR POLITICAL AND SOC. RESEARCF, UNITED STATES SUPREME COURT JUDICIAL DATABASE, 1953-1997 TERMS (9th ed. 1999). For this reason, we developed our own independent database of Supreme Court decisions, rather than drawing upon the Supreme Court Database. See infra Appendix B (describing our database).

${ }_{83}$ Puro, supra note 2. Hakman's article, supra note 16, preceded Puro's study. But Hakman provided no information about the influence of amicus briefs on outcomes.

${ }^{84}$ See Puro, supra note 2, at 21 (describing the study's methodology). 
time. ${ }^{85}$ Moreover, he found that the success rate of amicus filers increased over time: the success rate was only $44.4 \%$ in the period 1920 1936 ; it increased to $54.9 \%$ in $1937-1952$; and it rose to $60.3 \%$ in $1953-$ $1966 .^{86}$ Puro also provided an extensive breakdown of success rates according to type of legal issue, the status of the entity filing the brief, and whether the position being advocated was, in his judgment, "liberal" or "conservative."

Standing alone, Puro's findings regarding success rates might suggest that amicus filings have some modest but positive influence on outcomes, and that this influence was increasing during the period of his study. However, Puro did not claim to have uncovered any causal connection between amicus filings and Supreme Court outcomes. He noted that the Court tended to favor liberal positions during the period of his investigation, and that "underdog" groups were at that time more likely to file amicus briefs than were business groups or other conservative organizations. ${ }^{88}$ Thus, to the extent he suggested any explanation for his findings, it was that the Court was ideologically inclined to reach liberal outcomes, and that groups advocating liberal results were more likely to file amicus briefs, and hence more likely to be on the winning side.

Puro was well advised to exercise caution in drawing any strong causal conclusions from his success rates, if only because his aggregate data did not control for the impact of institutional litigants. Specifically, Puro's overall success rate of $55 \%$ was based on a sample of amicus filings which included such institutional litigants as the Solicitor General (who filed in over $17 \%$ of the amicus cases during the period), the ACLU (12.3\% of the cases), and the AFL-CIO (5.7\% of the cases). These institutional litigants enjoyed unusually high success rates during the period of his study. ${ }^{89}$ Moreover, the high success rates of such players in turn might be at least partly a function of their legal strategies. For example, they might seek to build up their credibility with the Court by filing frequently on the side they would pre-

${ }^{85}$ See id. at 96.

${ }^{86}$ See id. at 106 tbl.IV-3 (describing success rates across time periods).

87 See id. at 97 tbl.IV-1 (type of case); id. at 102 tbl.IV-2 (type of amicus); $i d$. at 111 tbl.IV-4 (ideological position).

${ }^{88}$ See id. at 254-55.

${ }^{89}$ Puro found that the Solicitor General had a success rate of $77 \%$ in the cases in which he filed an amicus brief, that the ACLU prevailed in $65 \%$ of its cases, and that the AFL-CIO (or its predecessor organizations, the AFL and the CIO) prevailed in $66 \%$ of its cases. See id. at 101, 103, 104. 
dict to be more likely to win. ${ }^{90}$ Or as Puro himself suggested, interest groups might file amicus briefs out of a desire to "look good" with their members, ${ }^{91}$ which might also cause them to file in cases in which they are most likely to win. To the extent interest groups pursue such a strategy, they will presumably lift their success rates, and hence to a degree the overall success rate for all amicus filers. But this would not signify any causal connection between amicus filings and outcomes.

More recently, Donald Songer and Reginald Sheehan attempted to measure the efficacy of amicus briefs by using a different investigative strategy. ${ }^{92}$ They sought to identify "matched pairs" of cases in which, in one case, only one party was supported by one or more amicus curiae briefs filed by an interest group and, in the other case, neither party had amicus support. The matched pairs had to be decided in the same Term, had to involve parties of the same status (viz., private individual, business, union, state or local government, or the federal government), and had to involve the "same issue" (i.e., both cases had to fall into one of thirteen general subject matter categories)..$^{93}$ Using data from ten Terms over a twenty-year period (1967 to 1987), Songer and Sheehan identified 132 such matched pairs of cases.

Analyzing their case pairs, Songer and Sheehan found no evidence of amicus group influence. The success rate of parties supported by interest group amicus briefs was virtually identical to that of parties without such support. Restricting the comparison to cases in which one side had at least two or three amicus supporters, they again found "no support for the thesis that interest groups have a substantial impact on Court outcomes through their use of amicus curiae briefs." ${ }^{\text {"94 }}$ They also found no variation in success rates among different categories of litigants, and no evidence of change in the pattern of influence over the twenty-year period under examination. ${ }^{95}$

${ }^{30}$ Cf. Thomas W. Merrill, High-Level, "Tenured" Lauyers, 61 LAW \& CONTEMP. PROBS., Spring 1998, at 95-99 (suggesting that the Solicitor General's office sometimes acts against its short-term interest in order to enhance its institutional reputation for good faith and honesty).

91 Puro, supra note 2, at 247.

${ }^{92}$ See Donald R. Songer \& Reginald S. Sheehan, Interest Group Success in the Courts: Amicus Participation in the Supreme Count, 46 POL. RES. Q. 339 (1993).

${ }^{93}$ See id. at 341-45 (explaining the research strategy).

94 Id. at $345-46$.

${ }^{95}$ The Songer and Sheehan study has potentially serious limitations. Although they referred to their research design as "precision matching," their criteria for deeming that pairs of cases involve the "same issue" were very crude. Id. at 342 . For example, all cases involving "labor management disputes" were regarded as presenting the "same issue," as were all cases involving "judicial power." Id. at 343 n.8. Moreover, 
In contrast, recent studies applying multivariate regression analysis to limited subsets of Supreme Court decisions have detected signs of a positive impact of amicus briefs on outcomes. Kevin McGuire has published two such studies, one seeking to identify the factors that affect the outcome of obscenity cases in the Supreme Court ${ }^{96}$ the other focusing on the relationship between the use of experienced lawyers and the probability of success in the Supreme Court. ${ }^{97}$ Both studies found that the probability of success was significantly related to the level of amicus curiae support for a party. But the more directly relevant of these studies-the one seeking to determine the factors influencing the outcome of obscenity cases-is vulnerable to the same criticism noted above in connection with Puro's study: it does not control for the influence of institutional litigants such as the Solicitor General. $^{98}$

Finally, a number of studies have sought to determine the degree of influence that particular institutional litigants, most prominently the Solicitor General, have achieved through their amicus filings.

Songer and Sheehan looked only at amicus briefs filed by interest groups. Thus, even if their study tells us something about the influence of interest groups on the Supreme Court, it does not necessarily tell us whether other amicus briefs (e.g., those filed by the Solicitor General or the States) are similarly lacking in influence.

Another recent study by Songer, conducted with Ashlyn Kuersten, examined the influence of amicus curiae briefs on state supreme courts. See Donald R. Songer \& Ashlyn Kuersten, The Success of Amici in State Supreme Courts, 48 POL. RES. Q. 31 (1995). Analyzing data pertaining to amicus filing in the Georgia, North Carolina, and South Carolina Supreme Courts from 1983 to 1990 , the study examined the relationship between amicus curiae filings and outcomes, using three measures: success rates, another study of matched pairs of cases, and multivariate regression analysis. In sharp contrast to Songer and Sheehan's matched-pair study of United States Supreme Court outcomes, all three measures showed that "support or opposition from amici is significantly related to litigants' chances of success in state supreme courts." Id. at 39 . Songer and Kuersten did not speculate as to why amicus curiae participation would have no impact on the United States Supreme Court, but would be associated with an increase of up to $30 \%$ in the success of litigants in state courts.

${ }^{96}$ See Kevin T. McGuire, Obscenity, Libertarian Values, and Decision Making in the Supreme Court, 18 AM. POL. Q. 47, 48 (1990).

${ }^{97}$ See Kevin T. McGuire, Repeat Players in the Supreme Court: The Role of Experienced Lauyers in Litigation Success, 57 J. POL. 187, 194 (1995).

${ }^{98}$ See McGuire, supra note 96, at 57 (noting the special influence of the Solicitor General but failing to account for this in the definition of the variable assigned to amicus influence).

${ }_{99}$ In addition to the studies of Solicitor General amicus success noted immediately below, see also Steven Puro, The United States as Amicus Curiae, in COURTS, LAW, AND JUDICIAL PROCESSES 220 (S. Sidney Ulmer ed., 1981) (examining the amicus behavior of the United States as part of its litigation strategy) and Karen O'Connor, The Amicus Curiae Role of the U.S. Solicitor General in Supreme Court Litigation, 66 JUDICATURE 256 (1983) (discussing significant impact of Solicitor General's office on public policy 
Jeffrey Segal has conducted a number of studies of the Solicitor General's amicus curiae activities. ${ }^{100}$ Looking at all cases decided between the 1952 and 1982 Terms, Segal found that the Solicitor General's amicus filings supported the winning side approximately $75 \%$ of the time overall. ${ }^{101}$ This high rate of success applied across all categories of issues, all changes in the Court's membership, and regardless of whether the Solicitor General was urging a liberal or a conservative result. $^{102}$ Segal's other studies show that amicus support by the Solicitor General is highly influential in determining the outcome of sex discrimination cases, after a number of other variables are controlled for, ${ }^{103}$ and that the Solicitor General's success is not related to the number of Justices appointed by Presidents of the same party as the Solicitor General. ${ }^{104}$ Rebecca Mae Salokar, reviewing all amicus cases decided by a full Court between 1959 and 1986, obtained similar results: the Solicitor General supported the winning side in $72 \%$ of the

through its involvement in litigation).

The Solicitor General typically represents the executive branch and most federal agencies in the Supreme Court. See Federal Election Comm'n v. NRA Political Victory Fund, 513 U.S. 88 (1994) (discussing 28 U.S.C. \$ 518(a)'s mandate to the Solicitor General to "conduct and argue suits and appeals in the Supreme Court ... in which the United States is interested"). See generally Neal Devins, Unitariness and Independence: Solicitor General Control over Independent Agency Litigation, 82 CAL. L. REV. 255 (1994); Todd Lochner, Note, The Relationship Between the Office of Solicitor General and the Independent Agencies: A Re-valuation, 79 VA. L. REV. 549 (1993). There are some exceptions. For example, the former Interstate Commerce Commission ("ICC"), the first major federal regulatory agency, was entitled to defend its orders before the Court if the Solicitor General elected not to do so. Because of such exceptions, there are some cases in which the Court has received more than one brief from federal entities charged with administering the law. See, e.g., Gordon v. New York Stock Exch., Inc., 422 U.S. 659, 660 (1975) (stating in syllabus that an amicus brief for the United States was filed by the Solicitor General, who urged the opposite result from an amicus brief filed by Securities Exchange Commission); Morris v. McComb, 332 U.S. 422, 426 (1947) (noting, in case where Solicitor General represented respondent, that Court had invited the ICC to file an amicus brief). An extreme example is Levinson v. Spector Motor Service, 330 U.S. 649 (1947), where over the course of two arguments (the case was reargued) the Court received three such amicus briefs: one from the ICC, another for the United States from the Solicitor General, and a third from the Administrator of the Wage and Hour Division, United States Department of Labor. See Levinson, 330 U.S. at 651 (listing those who filed amicus briefs).

${ }_{100}$ See infra notes 101-04 and accompanying text (describing Segal's studies).

101 See Jeffrey A. Segal, Amicus Curiae Briefs by the Solicitor General During the Warren and Burger Courts: A Research Note, 41 W. POL. Q. 135, 136 (1988).

${ }_{102}$ See id. at 138-39 (issues); id. at 141-42 (membership); id. at 141 (ideological positions).

${ }^{103}$ See Jeffrey A. Segal \& Cheryl D. Reedy, The Supreme Court and Sex Discrimination: The Role of the Solicitor General, 41 W. POL. Q. 553 (1988).

${ }^{104}$ See Jeffrey A. Segal, Supreme Court Support for the Solicitor General: The Effect of Presidential Appointments, 43 WESTERN POL. Q. 137 (1990). 
cases in which he filed an amicus brief, with no significant variations from one administration to the next. ${ }^{105}$

Studies of other institutional litigants have found less reason to believe that these litigants have a major impact on the Court. A paper by Thomas Morris suggested that state attorneys general are less successful than the Solicitor General in influencing the Supreme Court through amicus filings. ${ }^{106}$ A study undertaken by Gregg Ivers and Karen O'Connor found that the ACLU and Americans for Effective Law Enforcement achieved some success as amici curiae, but only when the Court was ideologically predisposed to reach the outcomes they favored. ${ }^{107}$

In sum, the existing empirical literature on the relationship between amicus briefs and Supreme Court outcomes provides confusing and contradictory results. Some studies, including those of Puro and the issue-specific multivariate regression analyses, suggest that amicus support is associated with enhanced chances of success. Other studies, such as Songer and Sheehan's matched pair study and the studies of institutional litigants other than the Solicitor General, show no relationship between amicus support and outcomes. The only finding that has been consistently replicated is that the Solicitor General enjoys a unique degree of success as an amicus filer.

\section{THREE MODELS OF JUDGING AND THEIR IMPLICATIONS FOR AMICUS BRIEFS}

One of the shortcomings of previous quantitative studies of amicus briefs is that they often fail to articulate a clear hypothesis about how information contained in amicus filings influences the decision making of the Supreme Court ${ }^{108}$ These studies nearly always presuppose some theory of judicial behavior. But often that theory is not made explicit, ${ }^{109}$ and only rarely is any linkage established between the

105 See Rebecca MaE Salokar, The Solictior General: The Politics of LAW 145-50 (1992).

106 See Thomas R. Morris, States Before the U.S. Supreme Court: State Attomeys General as Amicus Curiae, 70 JUDICATURE 298, 305 (1987).

${ }^{107}$ See Gregg Ivers \& Karen O'Connor, Friends as Foes: The Amicus Curiae Participation and Effectiveness of the American Civil Liberties Union and Americans for Effective Law Enforcement in Criminal Cases, 1969-1982, 9 LAW \& POL'Y 161 (1987).

${ }^{108}$ See, e.g., id. (noting the relationship between amicus briefs and court decisions, but making no claims of causality); McGuire, supra note 96 (same); Songer \& Sheehan, supra note 92 (same).

${ }^{109}$ For example, McGuire, supra note 97 , at 188, appears to adopt the attitudinal model. 
theory and a working hypothesis about how information influences the Court. Perhaps further progress can be made in understanding the impact of amicus briefs by delineating more precisely how different models of judicial behavior generate different hypotheses about how amicus briefs influence (or fail to influence) the Court. ${ }^{110}$ These hypotheses, in turn, suggest the different types of empirical results we should expect to find in examining large numbers of Supreme Court cases. Whether or not these results obtain may shed new light on which model of judging is most accurate. In this Part, we discuss three models of judicial behavior and specify the implications of each model in terms of the pathway of influence of amicus briefs. This in turn suggests, in a general way, the type of empirical results that would tend to corroborate or disprove the model.

\section{A. The Legal Model}

The first model, and the one with which lawyers will be most familiar, we call the legal model. ${ }^{111}$ As its name suggests, the legal model

${ }^{110}$ There is a small but growing body of literature that is self-consciously aware of the existence of rival models of judging and of the importance of these models to empirical evaluation of the courts. See, e.g., LAWRENCE BAUM, THE PUZZLE OF JUDICIAI BEHAVIOR passim (1997) (reviewing different models of judging found in political science literature); Ronald A. Cass, Judging: Norms and Incentives of Retrospective Decisionmaking, 75 B.U. L. REV. 941 (1995) (examining two models of judging in order to synthesize a new model); Christopher R. Drahozal, Judicial Incentives and the Appeals Process, 51 SMU L. REV. 469, 471 (1998) (constructing a model of judicial incentives and stating that such an approach "complements and refines" previous approaches); Thomas W. Merrill, Institutional Choice and Political Faith, 22 LAW \& SOC. INQUIRY 959, 973-87 (1997) (discussing various ways of differentiating courts from other institutions in a comparative institutional choice perspective); Posner, What do Judges and Justices Maximize?, supra note 13, at 7-31 (discussing various "maximands" that judges might have under a utility-maximization model); Gregory C. Sisk et al., Charting the Influences on the Judicial Mind: An Empirical Study of Judicial Reasoning, 73 N.Y.U. L. REV. 1377, 1385-92 (1998) (discussing behavioral, attitudinal, and legal models of judging); Frederick Schauer, Judicial Incentives and the Design of Legal Institutions, Paper Delivered at American Political Science Association Meeting (August 31, 1997) (manuscript on file with the University of Pennsylvania Law Review) (contrasting theories of judging based on self-interest with theories based on the pursuit of policy preferences);.

${ }^{111}$ This is the phrase employed by political scientists who specialize in quantitative studies of courts. See, e.g., SEGAL \& SPAETH, supra note 14, at 32 ("[T] he legal model ... postulates that the decisions of the Court are based on the facts of the case in light of the plain meaning of statutes and the Constitution, the intent of the framers, precedent, and a balancing of societal interests."); Frank B. Cross, Political Science and the New Legal Realism: A Case of Unfortunate Interdisciplinary Ignorance, 92 NW. U. L. REV. 251, 255-64 (1997) (discussing the origins and history of the traditional legal model). For a defense of the legal model in the context of a study of amicus briefs, see Hakman, supra note 16 , at $47-50$. 
posits that Justices resolve cases in accordance with their understanding of the requirements of the authoritative sources of law relevant to the question presented. These include the text of the applicable constitutional and statutory provisions, the structure and history of these provisions, precedents of the Court, and arguments about the policy consequences of different outcomes. ${ }^{112}$

The legal model is without doubt the "official" conception of how information, including that provided by amicus briefs, influences judges. Since 1990, the Court's rules governing the filing of amicus briefs have begun with this admonition:

An amicus curiae brief that brings to the attention of the Court relevant matter not already brought to its attention by the parties may be of considerable help to the Court. An amicus curiae brief that does not serve this purpose burdens the Court, and its filing is not favored. ${ }^{113}$

In other words, the Court's rules suggest that amicus briefs can influence the Court ("may be of considerable help to the Court") insofar as those briefs have value, both in the sense that they speak to the merits of the legal issue before the Court (supply "relevant matter") and provide new information ("matter not already brought to its attention by the parties").

The legal model is also the conception of the judicial role implicit in the procedures that the Court follows in deciding argued cases. Those procedures are designed to facilitate a careful sifting of arguments and authorities. They include the dialogic pattern reflected in the filing of opening briefs, followed by responsive briefs, followed by

${ }^{112}$ What we call the legal model is often presented in legal literature in a highly idealized form, as in the works advocating a "civic republican" model of judging. See, e.g., Frank Michelman, Law's Republic, 97 YALE L.J. 1493 (1988) (suggesting that republican theory can foster stronger judicial protection of individual rights than can competing theories); Mark Seidenfeld, A Civic Republican Justification for the Bureaucratic State, 105 HARV. L. REV. 1511 (1992) (arguing that the emphasis of civic republicanism on citizen participation in government is the best justification for modern administrative law); Cass R. Sunstein, Beyond the Republican Revival, 97 YALE L.J. 1539, 1579-85 (1988) (suggesting the application of republican concepts to the courts). As such, the model is vulnerable to the charge that it offers an unrealistic conception of the judicial process. But it is not necessary to assume that judges are heroic civic republicans in order to embrace the legal model. Chief Judge Posner has offered a model in which judges are depicted as consumers who derive pleasure from the "game" of deciding cases. See Posner, What Do Judges and Justices Maximize?, supra note 13, at 28-30. If one of the rules of this game is that judges should strive to decide cases correctly-i.e., in accordance with their understanding of the (highly complex) norms of the legal profession-then Posner's rational consumer model of judging should also yield behavioral predictions roughly similar to those of the legal model.

${ }^{113}$ SUP. CT. R. 37.1. 
reply briefs; the close questioning of counsel at oral argument; the exchange of views and preliminary votes at the conference of the Justices; and the circulation of draft opinions among the Justices for comment and revision before a final decision is reached. ${ }^{114}$ This sifting process can be seen as a collective weighing by the Justices of the strength of different legal perspectives with respect to the controversy at hand.

Notwithstanding the legal model's preferred status as reflected in the Court's rules and procedures, political scientists have long been intensely skeptical about whether the legal model has any explanatory power in predicting the outcomes reached by the Court. They note that the legal factors the Court considers are complex and have no fixed ordinal ranking. Thus, they contend, the legal model is open to manipulation and simply serves as a post hoc rationalization for results reached on political grounds. ${ }^{115}$

A proponent of the legal model might respond that it is unrealistic to demand that the law produce highly predictable outcomes, at least at the highest level of appellate litigation. The fact that the cases reaching the Supreme Court are those that produce disagreement among lawyers does not mean that law is irrelevant to the resolution of these disputes. The lawyers appearing before the Court debate these issues in terms of legal doctrine, ${ }^{116}$ and they frequently reach a consensus about which outcomes are most appropriate. Indeed, the fact that the Court rules unanimously in nearly $40 \%$ of its argued cases $^{117}$ suggests either that there is a strong core of agreement among the Justices about the law's requirements in a significant percentage of

${ }^{114}$ For an overview of the Court's procedures, see ROBERT L. STERN ET AL, SUPREME COURT PRACTICE 533-609 (7th ed. 1993), and WIILIAM H. REHNQUIST, THE SUPREME COURT: HOW IT WAS, HOW IT IS 271-303 (1987).

${ }^{115}$ See, e.g., SEGAL \& SPAETH, supra note 14, at 62-65 (asserting that the legal model is meaningless, since "various aspects of the legal model can support either side of any given dispute that comes before the Court"); cf. Cross, supra note 111, at 264 (noting numerous dismissive remarks by political scientists in referring to the legal model).

${ }^{116}$ See Ashutosh Bhagwat, Hard Cases and the (D)Evolution of Constitutional Doctrine, 30 CONN. L. REv. 961, 1016 (1998) (contending that the substantial amount of time that courts and academics devote to doctrine belies the argument that doctrine is incoherent, manipulable, and manipulated").

${ }^{117}$ See EPSTEIN ET AL., supra note 21, at 193-94 tbl.3-1 (listing the raw numbers and percentages of unanimous decisions for the terms from 1900 to 1994); see also J. Mitchell Pickerill, The Unanimously Ignored Issue of Unanimity and the Attitudinal Model 15 (Paper Presented at the Annual Meeting of the Midwest Political Science Association, Chicago, April 18-20, 1996) (manuscript on file with the University of Pennsylvania Law Review) (identifying unanimous decisions as a "potential problem" for advocates of the attitudinal model). 
cases, or at least that their disagreements are not sharp enough to provoke a dissent. ${ }^{118}$

Given the assumption of the legal model that Justices are anxious to resolve the cases before them correctly, in light of the complex norms of the legal profession, they should be eager to explore different legal perspectives on the issue, including different legal theories concerning how the issue should be resolved. These norms include, for many Justices, the social consequences of adopting different legal rules. Thus, these Justices should be receptive to "Brandeis Brief"-type information that sheds light on the wider social implications of the decision.

The legal model therefore generates a clear prediction about what results we should expect from an empirical study of amicus briefs. Amicus briefs should affect the likelihood of a party's success in the Supreme Court, but only insofar as they are of high quality, i.e., they provide new, legally relevant information to the Court beyond that supplied by the parties. The sheer quantity of amicus submissions, on

${ }^{118}$ Additional support for the constraining power of legal doctrine is provided by studies that look beyond the set of highly controversial Supreme Court decisions that garner the most public attention. For example, one study that looked to all of the Court's decisions on the merits, including both argued cases and per curiam opinions (which typically rest upon the application of precedent), found a high degree of internal agreement among the Justices. See Donald R. Songer \& Stefanie A. Lindquist, Not the Whole Stony: The Impact of Justices' Values on Supreme Count Decision Making, 40 AM. J. POL. SCI. 1049 (1996). Studies of lower federal court decision making designed to measure the influence of legal doctrine on outcomes have reached mixed results. Generally speaking, however, it appears that legal doctrine often acts as a significant constraint on the decisions reached by lower courts, although less so when those decisions are inherently discretionary or when review by higher level courts is unlikely. See, e.g., C.K ROWLAND \& ROBERT A. CARP, POLITICS AND JUDGMENT IN FEDERAL DISTRICT COURTS 34, 40, 48-50 (1996) (finding relatively little difference between Democratic and Republican district judges over all cases, but larger differences in cases involving controversial issues such as race relations, religion, and privacy); Orley Ashenfelter et al., Politics and the Judiciary: The Influence of Judicial Background on Case Outcomes, 24J. LEGAL STUD. 257, 281 (1995) (finding that "individual judge characteristics" have little power in explaining outcomes in federal district court decisions in civil rights cases); John R. Quinn, "Attitudinal" Decision Making in the Federal Courts: A Study of Constitutional Self-Representation Claims, 33 SAN DrEGO L. REV. 701 (1996) (finding little support for attitudinal model as opposed to legal model at district court level); Richard L. Revesz, Environmental Regulation, Ideology, and the D.C. Circuit, 83 VA. L. REv. 1717, 1743, 1763-64 (1997) (finding that outcomes in the D.C. Circuit in environmental cases are highly correlated with political party of appointing President, but cautioning that the strongest effects are shown in discretionary cases that are effectively immune from further review); Sisk et al., supra note 110, at 1498-99 (finding in study of district court decisions assessing the constitutionality of the Federal Sentencing Guidelines that desire to limit caseload and opportunity for promotion have some influence on outcomes, but so do legal factors, especially precedent). 
the other hand, should have little impact. Indeed, low-quality briefs that are merely repetitious should have no impact, or perhaps even a negative impact insofar as they "burden the Court," to use the Court's own phrase. Measuring "high quality" in a study that relies on counting large numbers of briefs in large numbers of cases is inherently problematic. Nevertheless, as reported in Part V we have attempted in our empirical study to devise various proxies for high-quality briefs in an effort to test this prediction. ${ }^{119}$

\section{B. The Attitudinal Model}

The second model of judicial behavior is the attitudinal model, which is today the dominant model used by political scientists studying the Supreme Court. ${ }^{120}$ The attitudinal model posits that the Justices decide cases in accordance with their political beliefs. ${ }^{121}$ These beliefs are assumed to be fixed by the time a Justice is appointed to the Court; the Justices do not change their ideological predispositions by interacting with their colleagues or by reflecting on the cases they hear or other information they acquire during their years on the Court. $^{122}$

Under the attitudinal model, individual Justices are viewed as each having a package of political "attitudes" that can be ranked along ordinal scales. These are usually scaled from "liberal" to "conservative," but are sometimes expressed more specifically, such as pro- to antideath penalty or pro- to anti-labor union. ${ }^{123}$ The model assumes that as cases presenting facts that implicate these attitudes arise, the outcomes are determined in accordance with the preferences of the majority of the voting Justices. Thus, if the issue involves a conflict be-

119 See infra Part V.C.

${ }^{120}$ See generally Cross, supra note 111, at 252 n.4 ("The attitudinal model has achieved predominance in political science scholarship."); Melinda Gann Hall \& Paul Brace, Justices' Responses to Case Facts: An Interactive Model, 24 AM. POL. Q. 237, 237-38 (1996) ("Without question, the attitudinal model has dominated the study of judicial choice and stands unchallenged as the best representation of voting on the merits in the nation's highest court."); Schauer, supra note 110, at 4-5 (noting that political scientists today overwhelmingly adopt some version of the attitudinal model).

${ }^{121}$ See SaUl BrenNer \& Harold J. SPAETH, STARE INDECISIS: THE Alteration OF PRECEDENT ON THE SUPREME COURT, 1946-1992, at 59-71 (1995); SEGAL \& SPAETH, supranote 14 , at 65 .

${ }_{122}$ See SEGAL \& SPAETH, supra note 14, at 6472.

${ }^{123}$ See id. at 242-55 (positioning Justices on a scale of "liberal" to "conservative" on a variety of issues); $i d$. at $222-25$ (scaling Justices as pro- to anti-death penalty); id. at 236 (characterizing Justice Frankfurter as "anti-union"). 
tween management and labor, and a majority of judges fall on the pro-labor end of the pro- to anti-labor scale, the party representing labor wins.

Lawyers and law professors usually react to the attitudinal model with hostility, regarding it as at best a caricature of the legal process. ${ }^{124}$ The proponents of the model acknowledge that it is highly reductionistic, but counter that any model of judicial behavior, if it is to be useful, must be "simpl[e] and parsimoniou[s]." ${ }^{125}$ They maintain that the attitudinal model, for all of its oversimplification, does a better job of predicting the outcomes of Supreme Court cases than any other model. ${ }^{126}$ It is this claim to predictive superiority, rather than any subtlety or verisimilitude, that has caused the attitudinal model to become the dominant approach to study of the Court among political

${ }^{124}$ See, e.g., Patricia M. Wald, A Response to Tiller and Cross, 99 CoLUM. L. REv. 235, 235 (1999) ("Judging is a complex, case-specific, and subtle task...; reducing the process to the level of checking a ballot box ... discredits the responsibility with which federal judges have been entrusted ...."); J. Randolph Block, Book Review, 1980 AM. B. Found. Res. J. 617, 624 (reviewing Harold J. SPAETH, Supreme Court POLICY MAKING: EVALUATION AND PREDICTION (1979), and concluding that the attitudinal model is nothing more than a simple "toy that gives intellectual pleasure and nothing else"). The principal response of the legal academy to the attitudinal model, however, has been silence. Legal academics who study courts are surprisingly ignorant of the empirical literature on courts being generated by social scientists. See Cross, supra note 111 , at 252-53 ("To date, legal scholarship has been remarkably oblivious to this large and mounting body of political science scholarship on courts."). The operational assumption of the attitudinal theory-that all judging is political-is of course similar to the operational assumptions of the Critical Legal Studies movement. See id. at 257-60 (noting that the "fundamental principle of CLS" is that the law is indeterminate and manipulated by "capitalist elites"). But CLS scholars are typically not very interested in quantitative empirical research, and have not discussed the findings of attitudinal scholarship. See id. at 257-58 (noting that some CLS scholars feel that empirical support is unneeded given that "CLS bases its theory of social change" on widely held assumptions in our political culture).

125 SEGal \& SPAETH, supra note 14, at 32.

${ }^{126}$ For notable studies finding the attitudinal model a better predictor of outcomes than the legal model, see, e.g., BRENNER \& SPAETH, supra note 121, at 109 (finding that "attitudinal variables" substantively explain the voting patterns of the Justices); Jeffrey A. Segal \& Albert D. Cover, Ideological Values and the Votes of U.S. Supreme Court Justices, 83 AM. POL. SCI. REV. 557, 561-63 (1989) (arguing that the attitudinal model is a successful predictor while noting some of its shortcomings); and Jeffrey A. Segal, Supreme Court Justices as Human Decision Makers: An Individual-Level Analysis of the Search and. Seizure Cases, $48 \mathrm{~J}$. Pol. 938, 941-43 (1986) (using the attitudinal model to explore voting patterns in search and seizure cases). Cf. Tracey E. George \& Lee Epstein, On the Nature of Supreme Court Decision Making, 86 AM. POL. SCI. REv. 323, 331-32 (1992) (finding that both the attitudinal model and the legal model have predictive power in death penalty cases, and proposing a synthesis). 
scientists. $^{127}$

The important point for present purposes is the implications of the attitudinal model for how Justices react to information beyond that supplied by the parties to a case. Under the attitudinal model, judges need very little information to decide cases.' Ordinarily, the list of "Questions Presented" in the petitioner's brief and the bare outlines of the underlying controversy should do. The assumption that Justices decide cases based on only a few key bits of information in turn suggests that it will be an extremely rare case in which amicus briefs will supply critical information that invokes a different preference and changes the outcome. ${ }^{128}$ In short, the attitudinal model generates what statisticians would call the null hypothesis: amicus briefs will have no discernible impact on outcomes. ${ }^{129}$

Recently, some political scientists have begun to question the assumption of the attitudinal model that the Justices do not modify their positions in light of information about how other institutional actors are likely to respond to their decisions. Instead, they have

127 Although the attitudinal model is usually encountered in its undiluted form in the writing of political scientists, it is not unfamiliar to lawyers. For example, it is primarily this model that underlies the exercise of "counting heads" used by lawyers in advising clients about possible outcomes of cases under appeal. See, e.g., Richard J. Lazarus, Counting Votes and Discounting Holdings in the Supreme Court's Takings Cases, 38 WM. \& MARY L. REv. 1099, 1102-03 (1997) (emphasizing the importance of counting votes to take account of the "rule of five"); Michael Stokes Paulsen, Counting Heads on RFRA, 14 CONST. COMMENTARY 7, 7-25 (1997) (engaging in nose-counting of Justices to predict that the Supreme Court would uphold the Religious Freedom Restoration Act). Moreover, at least one sitting Justice-Chief Justice Rehnquist-has intimated in some of his writings that he accepts something akin to the attitudinal model of the judicial process. See Thomas W. Merrill, Chief Justice Rehnquist, Pluralist Theory, and the Interpretation of Statutes, 25 RUTGERS L.J. 621, 632-38 (1994) (and sources cited therein).

${ }^{128}$ Segal and Spaeth are explicit on this point: “[I]nterest groups have little tangible to offer the justices, apart from some information-occasionally not otherwise available-that may marginally ease their reaching a decision. ... [W] have virtually no evidence to date that interest groups have an independent impact on Supreme Court decisions on the merits." SEGAL \& SPAETH, supra note 14, at 241.

${ }^{129}$ It is possible to imagine individualized exceptions to this generalization. For example, suppose a Justice favors organized religion, and is presented with a case in which a fringe religious group is contesting a decision by the Internal Revenue Service (IRS) to revoke its tax-exempt status. Cf. Hernandez v. Commissioner, 490 U.S. 680 (1989) (considering whether payments to the Church of Scientology for spiritual training sessions are tax deductible). On the face of the matter, it may be unclear whether the IRS's position is favorable or unfavorable to organized religion. One or two amicus briefs from mainstream religious bodies should help clarify this ambiguity, and would therefore guide the Justice ideologically predisposed to favor organized religion as to how to vote. But these situations presumably would be rare, certainly given the level of generality at which the decisive judicial values and attitudes are typically described by the proponents of the attitudinal model. 
sought to explain judicial behavior in accordance with a "strategic actor" model. ${ }^{130}$ This is essentially the attitudinal model with the added assumption that the Justices are rational actors who modify their voting behavior in order to maximize the chances of their ideological preferences actually being adopted as policy. Thus, the Justices do not vote in accordance with their "knee jerk" reaction to the facts of a case, but instead consider how other institutional actors are likely to respond to their decisions. In particular, the Justices will consider whether a given interpretation of a statute is likely to be overruled by Congress, or whether the recognition of a particular constitutional right is likely to be nullified by lackluster executive enforcement. ${ }^{131}$

Although it is difficult to derive testable hypotheses about the influence of amicus briefs from the strategic actor version of the attitudinal model, at least two predictions would seem to flow from this perspective. First, since the interests of the executive branch and of Congress are nearly always represented in the Supreme Court by the Solicitor General, one would expect a strategic Justice to pay very close attention to the amicus briefs filed by the Solicitor General. This might translate into higher success rates for the Solicitor General's amicus briefs relative to those of other filers. Similarly, though less dramatically, one would expect a strategic Justice to pay more than ordinary attention to the amicus briefs filed by the States since the States are often called upon to implement judicial decisions. This might translate into a somewhat higher success rate for the States as amicus filers relative to others.

\section{The Interest Group Model}

The third model of judging posits that Justices will seek to resolve

${ }^{130}$ See, e.g., BAUM, supra note 110 , at $89-124$ (concluding that Justices routinely vote strategically, rather than always following their own optimal policy preferences, in order to advance broader policy goals); LEE EPSTEIN \& JACK KNIGHT, THE CHOICES JUSTICES MAKE 10 (1998) ("[J]ustices are strategic actors who realize that their ability to achieve their goals depends on a consideration of the preferences of other actors, the choices they expect others to make, and the institutional context in which they act."); Revesz, supra note 118, at 1766-67 \& n.101 (collecting other studies applying a strategic actor model).

${ }^{191}$ For example, the Supreme Court's wavering path in interpreting federal civil rights legislation between the 1960s and the 1990s has been explained in terms of a strategic actor model that incorporates the Court's changing policy preferences, its perceptions as to how likely it is that Congress will vote to overrule its decisions, and its perceptions as to whether the President will veto an attempted overruling by Congress. See William N. Eskridge, Jr., Reneging on History? Playing the Court/Congress/President Civil Rights Game, 79 CAL. L. REV. 613, 642-46 (1991). 
cases in accordance with the desires of the organized groups that have an interest in the controversy. We call this the interest group model. Political scientists have long perceived an analogy between interest groups lobbying legislatures and interest groups seeking to influence judicial decisions through the filing of amicus briefs. ${ }^{132}$ More recently, some legal scholars influenced by public choice theory have begun to model the judiciary in accordance with the rational-maximizer assumptions of the interest group theory of politics. ${ }^{133}$ Indeed, the interest group model may be the dominant conception that amicus filers have today regarding their own efforts. ${ }^{134}$

What has not been perceived is that the interest group model of the judicial process, although it shares with the attitudinal model the basic hypothesis that judicial behavior is political, in fact adopts a very different assumption as to why judges behave politically. In contrast to the attitudinal model, which views judges as having fixed political beliefs and as seeking to advance those beliefs through judicial decisions, the interest group model depicts judges as having no fixed beliefs, but rather as seeking to satisfy the political demands of the bestorganized groups appearing before them. The distinction between the attitudinal model and the interest group model of judging thus exactly parallels the distinction in political science between the "ideological" and the "interest group" model of legislative behavior. ${ }^{135}$ In both literatures, the former model depicts government actors as utilizing their office in order to advance their view of the public good, while the latter model depicts government actors as utilizing their of-

132 See David B. Truman, The Governmental Process 479 (1951); Vose, supra note 76, at ix; Lucius J. Barker, Third Parties in Litigation: A Systemic View of the Judicial Function, 29 J. POL. 41, 41 (1967); Harper \& Etherington, supra note 60, at 1172 . See generally Epstein, supra note 36, at 336-45 (tracing the history of the interest group conception of the judicial process).

${ }^{133}$ See, e.g., KOMESAR, supra note 12, at 18-28, 123-50; Elhauge, supra note 12; Saul Levmore, Voting Paradoxes and Interest Groups, 28 J. LEGAI STUD. 259, 278-79 (1999); Thomas W. Merrill, Does Public Choice Theory Justify Judicial Activism After All?, 21 HARv. J.L. \& PUB. POL'Y 220 (1997).

${ }^{194}$ See Morriss, supra note 80 , at 829 ("[A]mici's view of their own efforts is akin to that of groups lobbying before Congress.").

195 See Daniel A. Farber \& Phil. P. Frickey, LAw and Public Choice: A CRITICAI INTRODUCTION 12-37 (1991) (reviewing studies purporting to show that legislators are primarily motivated by ideology and other studies purporting to show that they are primarily motivated by desire for reelection); Joseph P. Kalt \& Mark A. Zupan, Caplure and Ideology in the Economic Theory of Politics, 74 AM. ECON. REv. 279, 279, 298 (1984) (finding that economic models that view political actors as "narrowly egocentric maximizers" without taking account of legislators' ideologies poorly predict legislative outcomes). 
fice in order to maximize their own private good.

The immediate question raised by the interest group model is why Supreme Court Justices, who have lifetime tenure and guaranteed compensation, should care about the political demands of organized groups. Two possible reasons have been offered.

The first suggests that Justices have the same self-regarding tendencies that economists impute to other individuals to explain both market and non-market behavior. ${ }^{136}$ Thus, just as firms are assumed to maximize profits, and politicians are assumed (by analogy) to maximize their chances of reelection, so judges can be assumed (by further analogy) to maximize some private good they value. It is possible to imagine various private goods that lower court judges might seek to maximize, such as the chances of promotion to a higher judicial or executive office or the prospect of lucrative post-employment income as a private mediator. ${ }^{137}$ But at least at the Supreme Court level, the reputation of the judge (as measured by laudatory articles, honorific awards, invitations to make appearances at elite law schools and to conduct seminars at exclusive resorts, and the like) seems like the most plausible maximand. ${ }^{138}$ This concern with enhancing their reputation, the self-interest argument suggests, drives the Justices to adopt the preferred positions of the most influential interest groups, because these groups have the capacity to affect the Justice's reputation with key audiences.

An alternative explanation would focus not on each Justice's con-

${ }^{136}$ See JERRY L. MASHAW, GREED, GHaOS, AND GOVERNANCE 3 (1997) (discussing the rational-choice assumption "that people behave as if they were purely rational calculators of their own gains and losses from alternative courses of action").

${ }^{137}$ See POSNER, OVERCOMING LAW, supra note 13, at 109-17 (discussing various objectives judges might seek to maximize, including promotion, leisure, popularity, reputation, and the pleasure of playing the "judicial game"); Cross, supra note 111, at 294 97 (offering a broad array of the self-interests judges may seek to maximize, ranging from respect, to the ability to impose their personal views on society, to leisure time).

${ }^{138}$ As Lawrence Baum, supra note 110, at 47, observes, "there is no doubt that Supreme Court justices care about their standing with audiences outside the Court." He explains:

They frequently speak to legal groups and sometimes speak to other interest groups. They often work to obtain positive reactions from such groups; Benjamin Cardozo, for instance, "cultivated the good opinion of academics." Many justices pay attention to their depiction in the mass media, some grant interviews to journalists, and some respond to criticism in the press. Harry Blackmun read his mail from the public, and William Brennan cared about his portrayal in biographies. Several justices have maintained personal relationships with presidents, even at the risk of creating conflicts of interest.

Id. at 47-48 (citations omitted). 
cern about personal reputation, but rather on the Justices' collective concern about the prestige and power of the Court as an institution. Scholars who study the relationship between public opinion and the Court have long hypothesized that the Justices recognize that "the Court is a political institution whose authority depends on public deference and respect. ${ }^{\text {n199 }}$ Consequently, at least some Justices will modify their decisions "in response to what they individually perceive as long-term and fundamental changes in public opinion."140 Justice Roberts's famous "switch in time" to preserve New Deal programs from invalidation ${ }^{141}$ and Justice Kennedy's apparent reversal of position on whether to overrule Roe $v$. Wade are familiar examples.

Whatever the assumed source of the Justices' sensitivity to organized public opinion, the implications of the interest group theory for amicus activity are reasonably clear. In order to maximize their own public reputations or the reputation of the Court, the Justices need information about public opinion. How do they get such information? On some issues that reach the Court, such as whether abortions should be constitutionally protected or compulsory busing used to achieve integration in public schools, public opinion polling data is available. ${ }^{143}$ However, with respect to most issues the Court must decide-such as whether to recognize a psychotherapist's privilege (the issue in Jaffee $v$. Redmond) - there is no public opinion, or at least no polling data about public opinion. This does not mean, however, that specific interest groups do not have strong views about such issues. Those groups most affected by a decision are likely to have very pronounced views about how these issues should be resolved as a policy matter. Thus, in the vast run of cases that the Court decides, "public opinion" translates into "interest group opinion."

${ }^{139}$ William Mishler \& Reginald S. Sheehan, Public Opinion, the Attitudinal Model, and Supreme Court Decision Making: A Micro-Analytic Perspective, 58 J. POL. 169, 173 (1996). For other studies of the impact of public opinion on the Court, see THOMAS $R$. MARSHAII, PUBLIC OPINION AND THE SUPREME COURT (1989), and David Barnum, The Supreme Court and Public Opinion: Judicial Decision Making in the Post-New Deal Period, 47 J. POL. 652 (1985).

${ }^{140}$ Mishler \& Sheehan, supra note 139, at 174.

141 See Michael Ariens, A Thrice-Told Tale, or Felix the Cat, 107 HARV. L. REV. 620, 631-34 (1994).

${ }^{142}$ Compare Webster v. Reproductive Health Serv., 492 U.S. 490 (1989) (Kennedy, $\mathrm{J}$., joins plurality opinion declining to reaffirm Roe $v$. Wade) with Planned Parenthood $\mathrm{v}$. Casey, 505 U.S. 833 (1992) (Kennedy, J., joins opinion reaffirming central holding of Roe v. Wade).

${ }^{143}$ See EPSTEIN ET AL., supra note 21, at 679-95 (reporting longitudinal polling data on these questions). 
The interest group model therefore generates a third hypothesis about the role of amicus briefs in transmitting information to the Court. Insofar as the Justices are assumed to try to resolve cases in accordance with the weight of public opinion, they should look to amicus briefs as a barometer of opinion on both sides of the issue. Moreover, the information that amicus briefs convey about organized opinion is such that it can largely be assimilated simply by looking at the cover of the brief. The Justices can scan the covers of the briefs to see which organizations care strongly about the issue on either side. The fact that the organization saw fit to file the brief is the important datum, not the legal arguments or the background information set forth between the covers of the brief. ${ }^{144}$

The understanding that amicus briefs transmit the views of interest groups appears to be the animating idea of Justice Scalia's dissenting opinion in Jaffee. In Jaffee, Justice Scalia noted that fourteen groups, most of them representing different types of psychotherapists, filed amicus briefs in support of creating a "psychotherapist's privilege" in federal court. ${ }^{145}$ Such a privilege, by shielding psychotherapists from having to testify about information disclosed to them by patients while undergoing therapy, would enhance the value of therapeutic services and would elevate the prestige of therapists by associating their services with those provided by more traditional professionals such as lawyers. The filing of the fourteen briefs could be viewed as sending a clear message to the Court that the weight of organized public opinion strongly supported the recognition of such a psychotherapist's privilege. Thus, if the Justices are assumed to be concerned primarily with public opinion, amicus briefs offer a road map about how to rule.

The interest group model generates a clear prediction about what results we should expect from an empirical analysis of amicus briefs. We should expect to find that disparities in amicus support for one side over another would translate into a greater probability of success for the side with the greater support. Such disparities would signal to the Court that organized interest groups, and through them public

${ }^{144}$ Amicus briefs may also be a source of direct information about the policy preferences of other institutional actors. Epstein and Knight did a small random study of briefs filed in the 1990 Term and found that "the majority of briefs filed in constitutional and nonconstitutional cases attempt to define the preferences of other political actors." EPSTEIN \& KNIGHT, supra note 130, at 146.

${ }^{145}$ See Jaffee v, Redmond, 518 U.S. 1, 35-36 (1996) (Scalia, J., dissenting); see also supra text accompanying note 11 . 
opinion, are aligned with one side of the controversy rather than another. The greater the disparity of amicus support for one side, the more likely the Court will rule for that side. ${ }^{146}$ The quality of the legal analysis contained in amicus briefs, however, would make little difference to the outcome.

\section{AN EMPIRICAL STUDY OF THE INFLUENCE OF AMICUS BRIEFS}

In an effort to test these rival conceptions about the influence of amicus briefs, we undertook to conduct an empirical study. Unfortunately, the standard database used in studying the Supreme Court does not contain the bulk of the information necessary for such a study. For example, it does not include the number of amicus briefs filed in support of the different parties. ${ }^{147}$ Thus, it was necessary to develop our own database. (A complete description of the methodology that we followed and of a number of the variables that we tracked in assembling the database is set forth in Appendix B of this Article.)

Our database consists of all Supreme Court decisions from the beginning of October Term 1946 to the end of October Term 1995 in

146 It might be argued that the best measure of interest group support is the number of organizations that participate in the filing of amicus briefs, as opposed to the number of amicus briefs they file. Thus, for example, if 40 business organizations joined forces to file 10 amicus briefs in a case involving punitive damages, then the best index of interest group views might be the fact that 40 organizations participated in the effort, not that 10 briefs were filed. We reject this approach for two reasons, one methodological, the other theoretical. The methodological reason is that it would be impossible to tabulate the number of participating organizations based on the information supplied by the Reporter of Decisions in the United States Reports, because the Reporter typically lists only the first-named organization that appears on a brief, followed by the notation "et al." Thus, in order to gather the names of all participating organizations, it would be necessary to examine the original amicus briefs individually, an extraordinarily time-consuming task. The theoretical reason is that the strength of interest group support may best be measured by the total amount of resources that these groups are willing to expend in "lobbying" the Court. If the costs of filing an amicus brief fall within a relatively narrow range, then the number of amicus briefs may serve as a reasonably good proxy for the total amount of resources that groups are willing to spend. Certainly it is a better proxy than the number of groups that appear on the covers of the briefs (the larger the number of groups participating on each brief, the lower the expense for each of the participating groups). Large numbers of groups joining forces to file a small number of briefs thus might signal less intense concern with a case than would a larger number of briefs filed by a smaller number of groups. See also infra note 198.

${ }^{147}$ See supra note 82 (discussing INTER-UNTV. CONSORTIUM FOR POLTIICAL AND SOC. RESEARCH, UNITED STATES SUPREME COURT JUdICIAL DATABASE, 1953-1997 TERMS (9th ed. 1999)). 
which the Court heard oral arguments and rendered a decision on the merits or by dismissing declined to do so. For each of 6141 cases, we classified the outcome as falling into one of three categories: p-win (short for petitioner win), meaning that the judgment below was set aside; p-loss (short for petitioner loss), meaning basically that the judgment below was sustained or at a minimum not set aside; and mixed result, meaning that the judgment was partially sustained and partially set aside. ${ }^{148}$ Using the tabulation of amicus briefs at the beginning of each decision in the official United States Reports by the Reporter of Decisions, we also recorded for each case the number of amicus briefs supporting the petitioner, the number of amicus briefs supporting the respondent, and the number of amicus briefs not classified as supporting either party (we term this last category "other" briefs). ${ }^{149}$

In addition, we tracked the amicus curiae briefs of four institutional litigants-the Solicitor General, the American Civil Liberties Union, the AFL-CIO, and the States. Each of these four institutional actors frequently appears as amicus before the Supreme Court and has done so throughout the fifty years of our study. ${ }^{150}$ Moreover, each of these institutional litigants has been identified in the previous literature as being especially successful in influencing the Court through amicus curiae submissions. ${ }^{151}$ We wanted to test these assertions and also to be able to control for the impact of these litigants in assessing the effectiveness of other amicus filers.

We used our large database of decisions to try to answer three

${ }^{148}$ Supreme Court decisions do not come neatly packaged as victories or defeats for the parties. The Court uses an array of terms for its judgments, including "reversed," "vacated," "affirmed," "reversed in part and vacated in part," and so forth. We set forth in an appendix a description of the methodology we followed in categorizing outcomes. See infra Appendix B at notes 21-27 and accompanying text.

${ }^{149}$ See infra Appendix B at notes 12-20 and accompanying text (describing the Reporter's classification system).

${ }^{150}$ This distinguishes these groups from other institutional litigants that could also have been interesting to track. For example, the American Medical Association, though appearing as amicus as early as 1926, see Lambert v. Yellowley, 272 U.S. 581, 587 (1926), did not become a regular filer until well after even the halfway point of our study, see, e.g., Rhodes v. Chapman, 452 U.S. 337, 339 n.* (1981); Massachusetts Bd. of Retirement v. Murgia, 427 U.S. 307, 308 n.* (1976); id. at 323 n.4 (Marshall, J., dissenting). Such relatively recent emergence also characterizes the American Psychological Association. See, e.g., Parham v. J.R., 442 U.S. 584, 587 n.*, 606 (1979); Maxwell v. Bishop, 398 U.S. 262, 263 (1970).

${ }^{151}$ See, e.g., Ivers \& O'Connor, supra note 107, at 169 (discussing the success rate of the ACLU); Puro, supra note 2, at 101-04 (discussing the success rates of each of these filers). 
questions, corresponding to our three models of judging and their associated hypotheses. The first, which was suggested by the attitudinal model, is whether amicus briefs in general have any measurable impact on the outcomes reached by the Supreme Court. The second, which was stimulated by Justice Scalia's dissenting opinion in Jaffee $v$. Redmond ${ }^{152}$ and the interest group model, is whether disparities in amicus support for one side or another have an impact on the outcomes reached by the Supreme Court. The third, which is responsive to the legal model, is whether high-quality amicus briefs have an impact on outcomes reached by the Court.

\section{A. The Overall Success Rates of Amicus Filers}

The earliest studies of amicus briefs by political scientists sought to determine the influence of such briefs by computing the overall success rates of amicus filers-how often amicus filers prevail relative to some underlying benchmark of outcomes. ${ }^{153}$ It makes sense to repeat this exercise using our large and updated database. More to the point, the overall success rate sheds light on the attitudinal model. Under the attitudinal model, a high success rate for any particular amicus group could be explained on the ground that a majority of the Justices shares the same political attitudes as the group. But if hundreds of different amicus filers reflecting every possible viewpoint are collectively associated with parties that achieve greater success relative to parties that lack amicus support, this would tend to cast doubt on the attitudinal model. Accordingly, we computed the success rates for amicus filers both over the entire span of our study and by decade.

In assessing the impact of amicus filers in general, the point of departure is to determine the benchmark rate of success for petitioners and respondents without regard to amicus support. We computed the benchmark rate by determining the mean $p$-win and $p$-loss rate for petitioners and respondents in cases in which no amicus briefs were filed. Rounding to whole numbers, we found that in such cases petitioners are successful $60 \%$ of the time, respondents are successful $37 \%$ of the time, and mixed results are obtained $3 \%$ of the time. ${ }^{154}$ Figure

152 518 U.S. 1, 18 (1996); see supra text accompanying notes 10-11, 145.

${ }^{153}$ See, e.g., supra text accompanying notes 83-91 (discussing Puro's calculation of a base rate of amicus success); Songer \& Sheehan, supra note 92, at 345 (comparing success rates of parties supported by amici with success rates of parties not supported by amici).

${ }^{154}$ More precisely, for cases in which no amicus briefs were filed, petitioners achieved success $59.77 \%$ of the time, respondents achieved success $36.85 \%$ of the time, 
6 summarizes the benchmark rates of success overall and by decade.

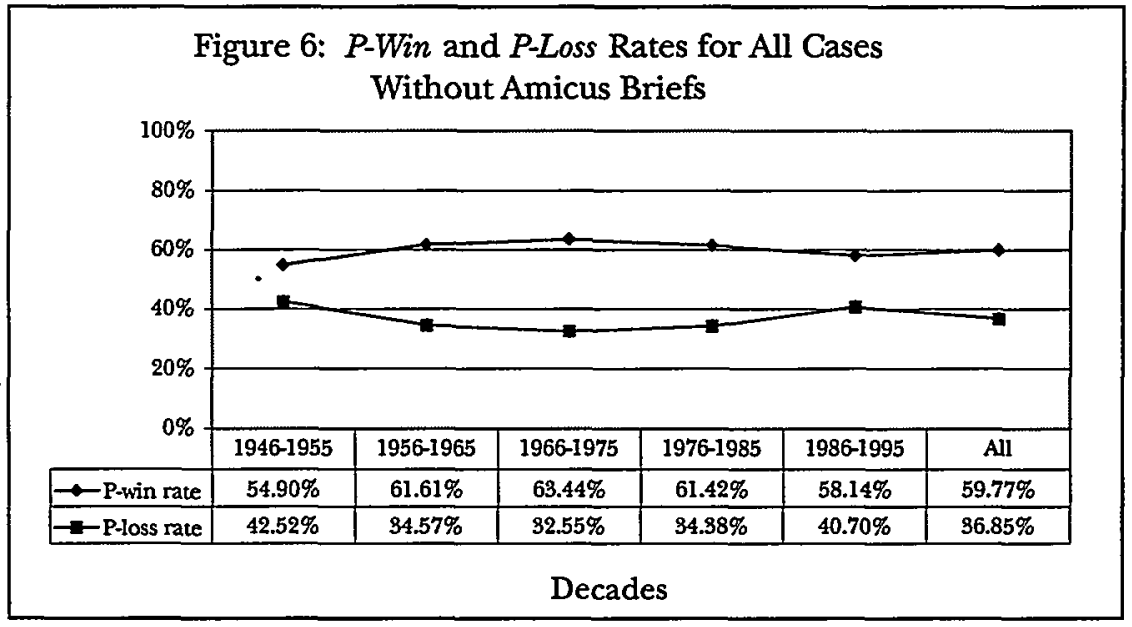

\begin{tabular}{|l|c|c|c|c|c|c|}
\hline Data Undenlying Figure 6 & $1946-1955$ & $1956-1965$ & $1966-1975$ & $1976-1985$ & $1986-1995$ & All \\
\hline P-wins & 448 & 483 & 380 & 234 & 100 & 1645 \\
\hline P-losses & 347 & 271 & 195 & 131 & 70 & 1014 \\
\hline Mixed results & 21 & 30 & 24 & 16 & 2 & 93 \\
\hline
\end{tabular}

Our benchmark rates of success are themselves an important empirical payoff of the study. Previous studies have found that the Supreme Court is more likely to rule in favor of petitioners than respondents. ${ }^{155}$ Analysts have suggested that this reflects the fact that one factor that presumably motivates the Court to grant review is the perception of at least four Justices that the case below was wrongly decided. ${ }^{156}$ Our large database not only confirms that petitioners fare better than respondents, but allows us more precisely to quantify the disparate success of petitioners.

Given that the benchmark rates of success vary slightly by decade, we have used decade-specific success rates in reporting data. As a rule, however, we do not in our presentation of results use different benchmark rates of success for petitioners and respondents. Instead, we focus solely on whether filers supporting petitioners have increased the $p$-win rate above the p-win benchmark and on whether filers sup-

and mixed results were achieved $3.38 \%$ of the time.

155 See, e.g., Segal, supra note 101 , at 140 (noting that the typical success rate for respondents is $33 \%$ ).

${ }^{156}$ See, e.g., Virginia C. Armstrong \& Charles A. Johnson, Certiorari Decisions by the Warren and Burger Courts: Is Cue Theory Time Bound2, 15 POLITY 141, 150 (1982). 
porting respondents have reduced the p-win rate below the p-win benchmark. This introduces a small amount of inaccuracy, since the p-win benchmark is not exactly the obverse of the p-loss benchmark, given that the percentage of mixed results (which is $3 \%$ overall) varies slightly from decade to decade. But the alternative of using separate benchmarks for filers supporting petitioners and filers supporting respondents would have made the exposition of results more complicated and potentially confusing. We concluded that a small amount of inaccuracy was a price worth paying for a more simplified and comprehensible presentation.

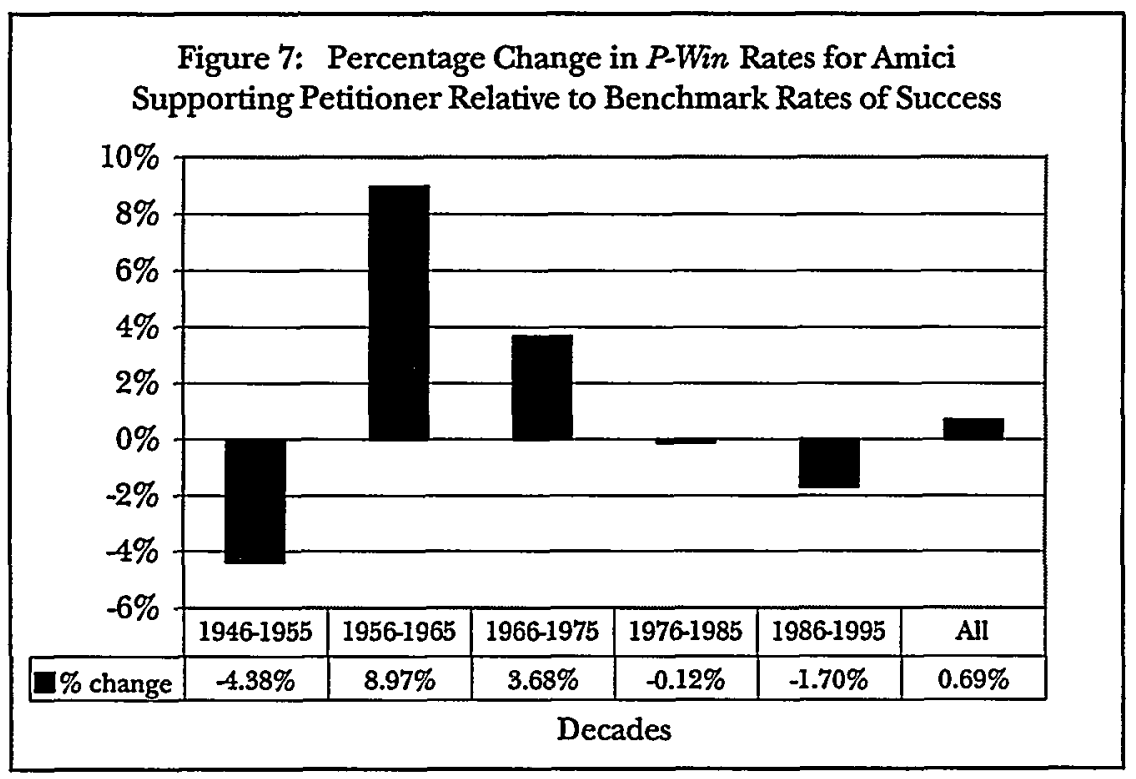

\begin{tabular}{|c|c|c|c|c|c|c|}
\hline Datalindatiog Figue 7 & $1946-1955$ & $1956-1965$ & $1966-1975$ & $1976-1985$ & 1986-1995 & AI \\
\hline Nimber of Petitioner's Amias Briefs Registering $R W Z n$ & 146 & 283 & 549 & 998 & 1118 & 3094 \\
\hline Number of Petitioner's Amias Bief Registering $R$ Loss & 118 & 105 & 223 & 531 & 739 & 176 \\
\hline 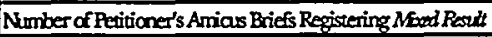 & 25 & 13 & 46 & 99 & 124 & 307 \\
\hline Toel Number of Petitioner's Amias Briefs & 299 & 401 & 818 & 1088 & 1981 & 5117 \\
\hline
\end{tabular}

Figures 7 and 8 summarize the extent to which amicus filers supporting petitioners and amicus filers supporting respondents have achieved results that diverge from the benchmark $p$-win rates over the fifty years of our study. ${ }^{157}$

${ }^{157}$ Specifically, Figure 7 compares the p-win rates of amicus briefs supporting petitioners (i.e., the number of amicus briefs supporting petitioners whose petitioners win divided by the total number of amicus briefs supporting petitioners) to the benchmark 
As can be seen from the last column in Figure 7, the success rate of amicus filers supporting petitioners over the entire fifty-year span differs very little from the benchmark rates of success. Amicus filers supporting petitioners obtained a p-win rate less than $1 \%$ higher than the benchmark rate of success. When we break the results down by decade, we see some intriguing variations. Filers supporting petitioners exceeded the benchmark in the second (Warren Court) decade of 1956-1965 by nearly $9 \%$, and beat the benchmark success rate in the third (Warren Court/Burger Court) decade of 1966-1975 by slightly less than $4 \%$. In the last two decades, however, filers supporting petitioners were much more numerous and achieved success at rates that hover just under the benchmark rates of success, bringing the overall result closely in line with the benchmark rate. It is possible, therefore, that amicus filers supporting petitioners had some effect on outcomes from 1956 to 1975 , but then lost this advantage as the numbers of amicus briefs surged in the last two decades.

When we turn to filers supporting respondents, we see a different picture. Filers supporting respondents have experienced a consistent degree of success relative to the benchmark rates of success throughout the period of our study. Overall, as reflected in Figure 8, amicus filers supporting respondents obtained a $p$-win rate of less than $53 \%$, which, for a filer supporting respondents, is substantially better than the benchmark rate of $60 \%$. When we break down the results by decade, we see that filers supporting respondents have consistently outperformed the benchmarks. Moreover, filers supporting respondents, unlike filers supporting petitioners, have continued to do better than the benchmark rates in the last two decades. As we shall see, our data show in a variety of contexts that amicus briefs supporting respondents have greater success than amicus briefs supporting petitioners.

\footnotetext{
p-win rates reflected in Figure 6 . Figure 8 compares the p-win rates of amicus briefs supporting respondents (i.e., the total number of amicus briefs supporting respondents where petitioners win divided by the total number of amicus briefs supporting respondents) to the benchmark p-win rates.
} 


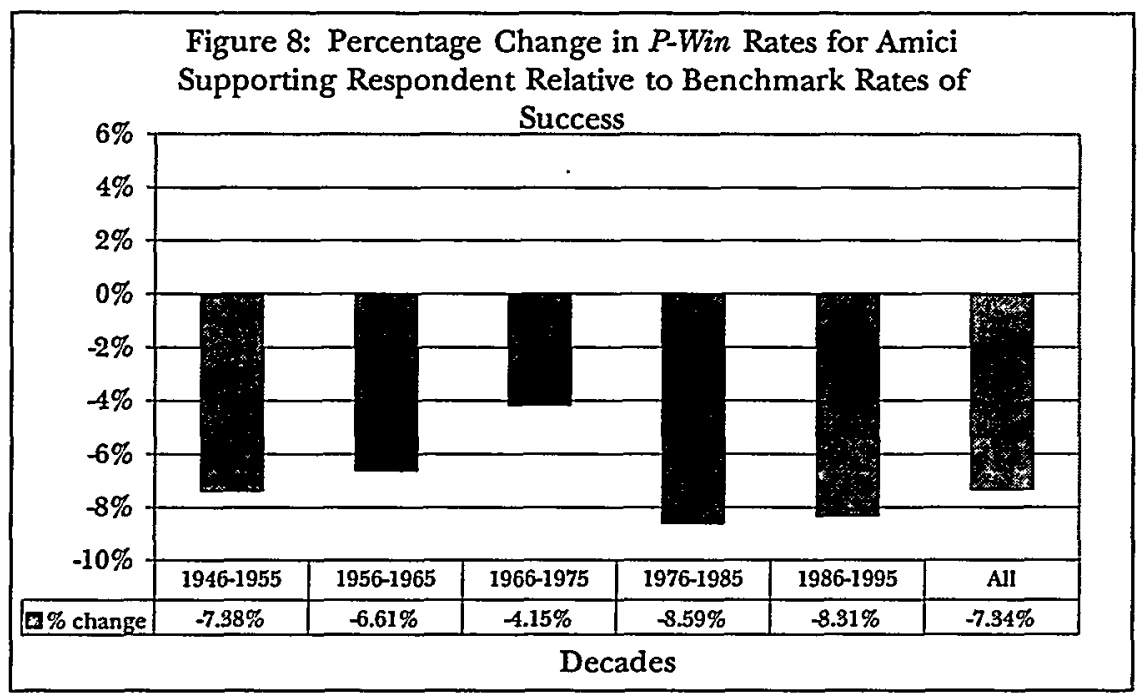

\begin{tabular}{|c|c|c|c|c|c|c|}
\hline Dota Underging Figure 8 & $1946-1955$ & $1956-1965$ & $1966-1975$ & I976-1985 & $1986-1995$ & All \\
\hline Number of Respondent's Amiars Briefs Registering P-Wn & 96 & 143 & 434 & 943 & 1033 & 2649 \\
\hline Number of Respondent's Amias Briefs Registering P.Lass & 100 & 107 & 268 & 711 & 914 & 2100 \\
\hline Nismber of Respondent's Amiaus Briefs Registering Mired Resull & 6 & 10 & 80 & 191 & 126 & 303 \\
\hline Toul Number of Respondent's Amiars Briefs & 202 & 260 & 732 & 1785 & 2073 & 5052 \\
\hline
\end{tabular}

\section{B. Disparities in Amicus Support}

One of the primary reasons we developed our large database of decisions is that we wanted to gather as many cases like Jaffee $v$. Redmond as possible in order to test the interest group theory. That is, we wanted to uncover a subset of cases involving extreme disparities of amicus support of a magnitude similar to Jaffee, where the petitioner had no amicus support and the respondent was supported by fourteen briefs. Somewhat to our surprise, we discovered that no such subset of cases exists. Jaffee is in a league by itself. Based on the Reporter's classification of amicus briefs, no other case in our database of 6141 decisions had a disparity of at least fourteen briefs on one side and zero on the other. ${ }^{153}$

${ }^{158}$ Jaffee itself is classified by the Reporter as having 12 amicus briefs supporting respondent, and two briefs are not shown as supporting either party (they are in the "other" column). See Jaffee v. Redmond, 518 U.S. 1, 3 \& n.* (1996). Individual examination of these two briefs reveals, as Justice Scalia reported, that they in fact also support respondent.

The largest disparity in a case with no briefs in the "other" column occurred in 
We were therefore forced to examine the effect of much smaller disparities in amicus support in order to consider the interest group model. "Disparities" in this context could be measured in different ways. They could be measured in terms of the absolute difference between the number of amicus briefs supporting one side and the number of amicus briefs supporting the other side. Alternatively, they could be defined in terms of the ratio of the number of briefs supporting one side relative to the number of briefs supporting the other side. Finally, they could be measured in terms of multiples of briefs supporting one side with no briefs supporting the other side. Each measurement presents its own problems, especially in terms of handling the briefs in the "other" column. We settled on the last measure because it struck us (as it apparently did Justice Scalia in Jaffee) as the type of disparity most likely to suggest to the Court that organized groups are aligned in favor of one side of a case rather than the other. In other words, we studied cases in which there were one, two, or three or more briefs supporting petitioner, none supporting respondent, and none in the "other" column ( $x-0-0$ cases), and then studied cases in which there were one, two, or three or more briefs supporting respondent, none supporting petitioner, and none in the "other" column (0-x-0 cases). ${ }^{159}$

United States v. Winstar Corp., 518 U.S. 839 (1996). (For a discussion of the "other" column and the briefs that fall into that column, see infra Appendix B notes 15-20 and accompanying text.) In Winstar, no briefs were filed in support of the petitioner, the United States, and 12 briefs were filed in support of the respondents, two Savings \& Loan Associations. As in Jaffee, the side supported by the amici prevailed. The next largest disparities in cases with no amicus briefs in the "other" column occurred in two cases in which 10 briefs were filed for the petitioner and none for the respondent, with one case resulting in a p-win and the other in a mixed result. See Lau v. Nichols, 414 U.S. 563, 563-64 n.* (1974); Lindsey v. Normet, 405 U.S. 56, 57-58 (1972).

Moreover, only five cases in the entire database had enough briefs in the "other" column to show even potentially the type and degree of disparity found in Jaffee-i.e., at least 14 briefs in fact supporting petitioner or respondent and none in fact either supporting the other party or constituting true "other" briefs. When we examined the briefs in these five cases, it turned out that none was marked by a Jaffee-type disparity. See Medtronic, Inc. v. Lohr, 518 U.S. 470 (1996) (listing 17 "other" briefs, none as urging reversal or affirmance); Newark Morning Ledger Co. v. United States, 507 U.S. 546 (1993) (listing eight amicus briefs as urging reversal and eight "other" briefs); Planned Parenthood v. Casey, 505 U.S. 833 (1992) (listing one brief as urging affirmance and 30 "other" briefs); Roe v. Wade, 410 U.S. 113 (1973) (listing 15 "other" briefs, none as urging reversal or affirmance); Swann v. Charlotte-Mecklenburg Bd. of Educ., 402 U.S. 1 (1971) (listing 20 "other" amicus briefs, none as urging either reversal or affirmance).

${ }^{159}$ In both instances we lumped together all cases with three or more briefs on one side in order to generate a large enough number of cases to make the statistical analysis potentially meaningful. For the reason explained in Appendix $\mathrm{C}$, these numbers 
Figure 9: Percentage Change in $P$-Win Rate for All x-0-0 Disparity Cases

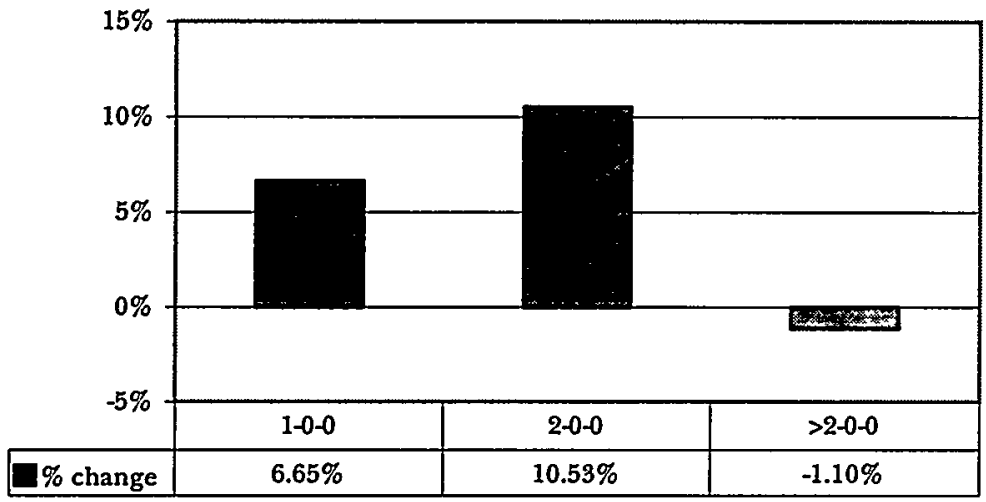

Number of Amicus Briefs Supporting: Petitioner-Respondent-Other

\begin{tabular}{|l|c|c|c|}
\hline Data Underlying Figure 9 & $1-0-0$ & $2-0-0$ & $>2-0-0$ \\
\hline Number of Cases & 545 & 165 & 121 \\
\hline
\end{tabular}

Our first step was to compare the rates of success over all the cases in our database that fit this definition of disparity against the benchmark rate of success ( $p$-win $=60 \%$ ). Figure 9 depicts the increase in $p$ win rates that we found with different degrees of disparity favoring the petitioner. The interest group model predicts that higher levels of disparity for petitioner should increase the success rate of petitioners above $60 \%$. What we see tends to support this hypothesis, at least for disparities of one and two amicus briefs. When one amicus brief is filed in support of petitioner and none for respondent, the p-win rate rises by nearly 7\%. When two amicus briefs are filed in support of petitioner and none for respondent, the $p$-win rate rises by more than $10 \%$. When we reach a disparity of three or more briefs, however, the results no longer correspond to the prediction of the interest group hypothesis. Indeed, the success rate of petitioners drops slightly below the benchmark rate of success, a puzzling result.

are all technically statistically significant, because we are not sampling. See also supra note 50. Subsets with small numbers (e.g., $N<30$ ) nonetheless present a related problem of substantive significance. While we have avoided the pitfalls of sampling with a small $n$, there is the possibility of "skewness" in our data, in that a few cases or parties may be acting as outliers and pulling the data in unusual ways that would not occur with more cases. 
Figure 10 shows the parallel findings with respect to disparities of amicus support for the respondent. Here, the hypothesis we are testing predicts that increasing levels of disparity should push the p-win rates below the benchmark level of $60 \%$. The pattern we uncover resembles that seen with respect to disparities of support for petitioners. The success rate follows the predicted pattern with respect to disparities of one brief and two briefs, with respondents supported by one amicus brief reducing the $p$-win rate by slightly over $4 \%$ and those supported by two amicus briefs reducing the p-win rate by somewhat more than $10 \%$. When we reach the third column, for disparities of three or more, the differential shrinks back toward the benchmark, as it did with three or more briefs on the petitioner side, although this time the change in the success rate is still in the predicted direction (a greater than $3 \%$ reduction in $p$-win rate).

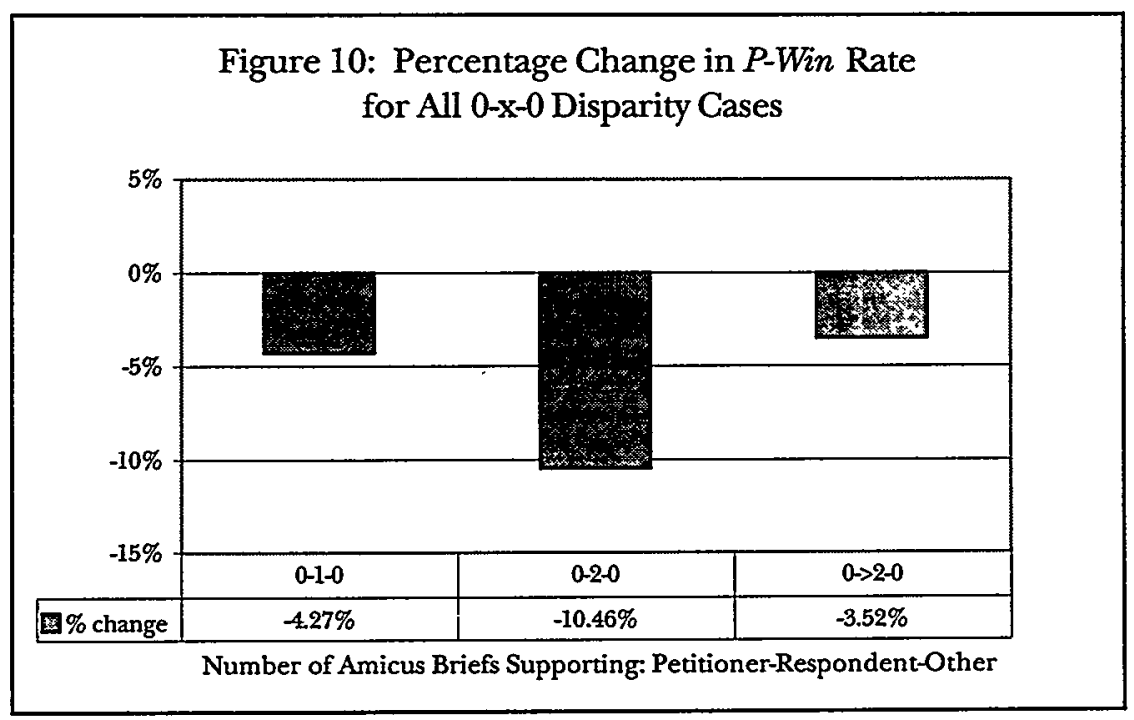

\begin{tabular}{|l|c|c|c|}
\hline Data Underlying Figure I0 & $0-1-0$ & $0-2-0$ & $0->2-0$ \\
\hline Num ber of Cases & 400 & 146 & 112 \\
\hline
\end{tabular}


These results, which reflect all cases in the database falling within the $x-0-0$ and $0-x-0$ pattern, appear to provide some support for the hypothesis that disparities of amicus support affect success rates, at least for small disparities of one or two briefs on one side and none on the other. As our survey of the prior literature suggests, however, it is important to control for the influence of institutional litigants, especially the Solicitor General. Given our large pool of cases, it was possible to do this simply by re-running the analysis looking at only those cases in which the Solicitor General did not file an amicus brief. When we analyzed the cases in which the Solicitor. General was not an amicus filer, we discovered that the success rates with different degrees of disparity were close to the benchmark success rate in almost all instances. Only with a disparity of three or more on the petitioner's side and of two on the respondent's side did we find substantial effects. ${ }^{160}$ This suggests that the influence on success rates shown in the aggregate data may largely be a product of the influence of the Solicitor General as an amicus filer when included as a component part of the aggregate data.

On further consideration, however, we realized that removing the Solicitor General as an amicus filer did not fully neutralize the Solicitor General's influence. Prior studies suggest that the Solicitor General enjoys extraordinary success not only as an amicus filer, but also as a party. ${ }^{161}$ Accordingly, we re-ran the disparity analysis looking only at cases in which the Solicitor General did not participate in any capacity, either as an amicus or as a party. Figures 11 and 12 report the results. We found, somewhat to our surprise, that when the Solicitor General is completely eliminated from the picture, disparities of ami-

${ }^{160}$ In cases where the Solicitor General was filtered out as amicus (but not as a possible party), disparities favoring petitioner at levels 1-0-0 ( $N=396)$ and 2-0-0 $(N=113)$ produced, respectively, $0.58 \%$ and $3.94 \%$ increases in p-win rates from the benchmark of $59.77 \%$. Disparities favoring petitioner at levels of $>2-0-0(N=79)$, however, decreased the p-win rate by 7.88\%. Disparities favoring respondent at levels of $0-1-0 \quad(N=359)$ decreased p-win outcomes by just $1.28 \%$, while those at $0-2-0$ level $(N=128)$ decreased the $p$-win rate by $8.21 \%$. At the $0 \rightarrow 2-0$ level $(N=100)$, p-win outcomes were not significantly changed from the benchmark rate, increasing by just $0.23 \%$.

${ }_{161}$ See, e.g., EPSTEIN ET AL., supra note 21, at 632 tbls.7-13 (listing success rates of the United States as a party before the Supreme Court); Kevin T. McGuire, Explaining Executive Success in the U.S. Supreme Court, 51 POL. RES. Q. 505, 507, 522 (1998) (discussing various theories explaining the success of the Solicitor General before the Supreme Court); Reginald S. Sheehan et al., Ideology, Status, and the Differential Success of Direct Parties Before the Supreme Court, 86 AM. POL. SCI. REV. 464, 466 (1992) (noting that Solicitor General enjoys "very large net advantages against all other parties" before the Supreme Court). 
cus support appear once again to be associated with greater success; indeed, small disparities have a greater impact on this subset of the database than they do with respect to disparities over all the cases in the database (Figures 9 and 10). As shown in Figure 11, with the first brief supporting petitioners, the success rate of petitioners rises by almost 7\%; with the second brief, it rises a remarkable $19 \%$. The success rate with three or more briefs again falls back toward the benchmark rate, but still remains over $8 \%$. The number of cases each column represents is not large, but in no case does it fall below forty.

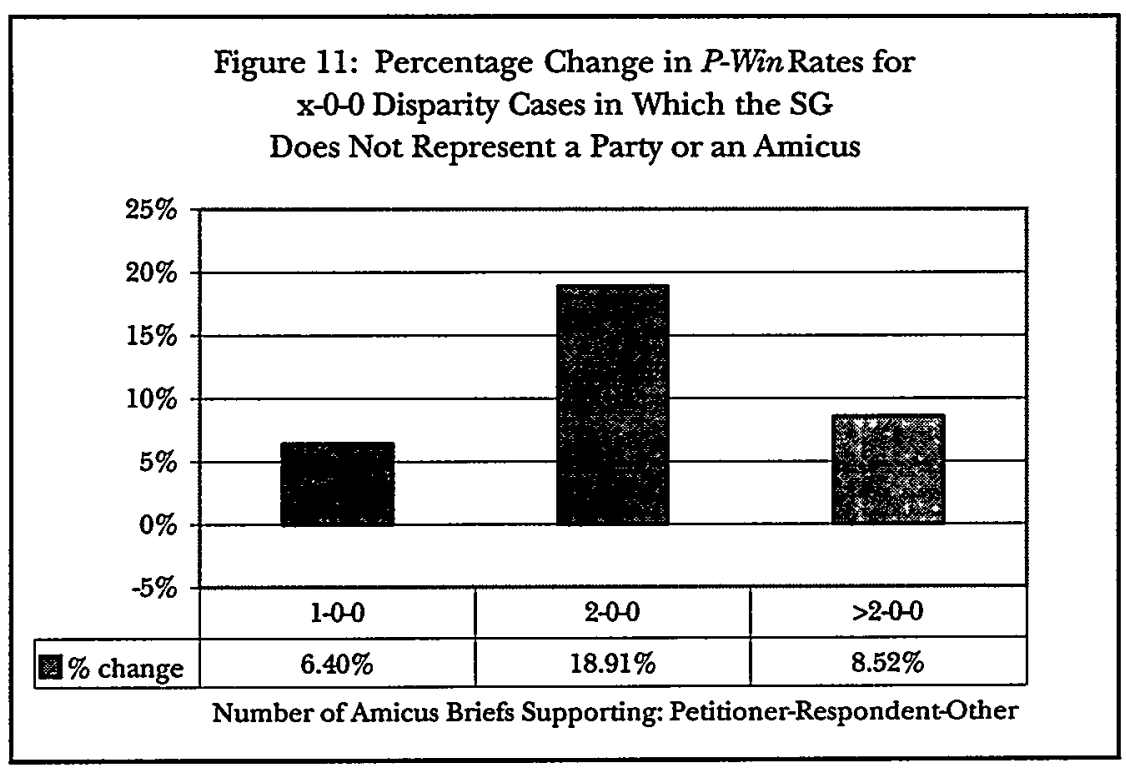

\begin{tabular}{|l|c|c|c|}
\hline Data Underlying Figure 11 & $1-0-0$ & $2-0-0$ & $>2-0-0$ \\
\hline Num ber of Cases & 204 & 61 & 41 \\
\hline
\end{tabular}


On the respondent's side, as reflected in Figure 12, the impact of disparities once the Solicitor General is altogether removed from the picture is even more dramatic. With the first amicus brief supporting respondents, the p-win rate falls by more than $14 \%$; with the second brief, it falls a striking $24 \%$. Little effect is shown at three briefs and higher, but the number of those cases here is relatively small. It may be, therefore, that disparities of amicus support have an impact on outcomes, at least for small disparities of one or two briefs to none, but that this effect is masked by the considerable success of the Solicitor General as a Supreme Court litigant and thus clearly appears only in cases where the Solicitor General is not involved.

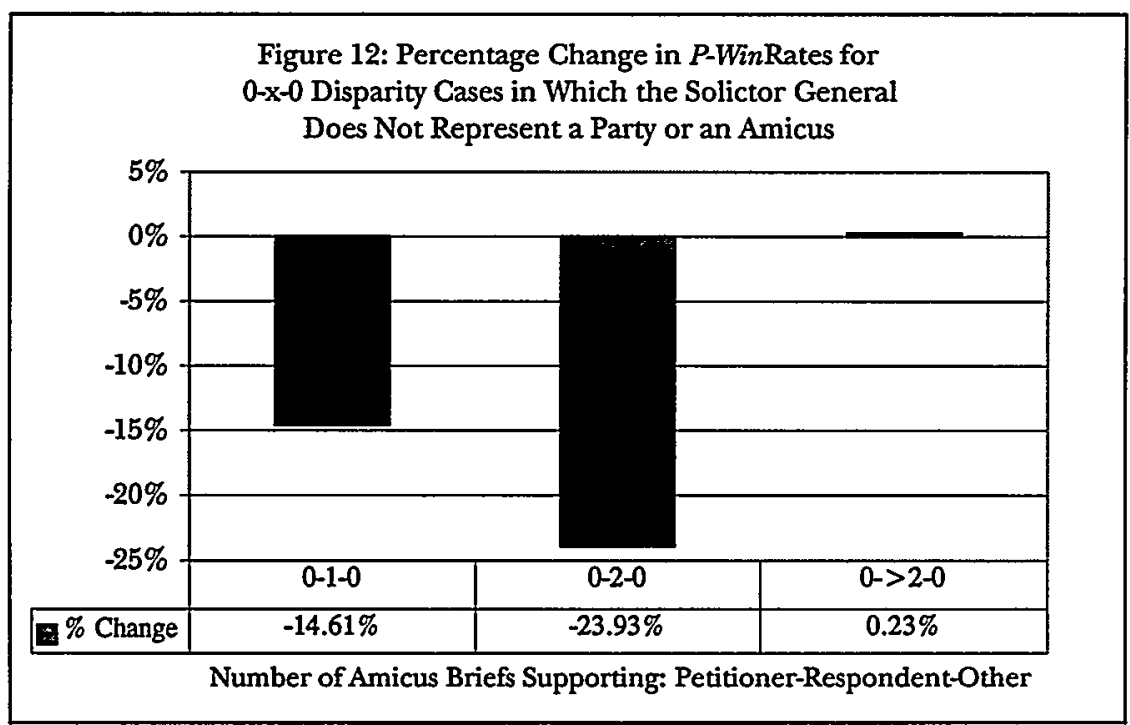

\begin{tabular}{|l|c|c|c|}
\hline Data Underlying Figure 12 & $0-1-0$ & $0-2-0$ & $0->2-0$ \\
\hline Num ber of Cases & 155 & 53 & 40 \\
\hline
\end{tabular}

The findings up to this point are based on observing the change in win rates for petitioner by comparing means across different categories of amicus involvement. In order to confirm our findings and to consider the substantive significance and impact of specific case-level variables on p-win rates across the entire population of cases, we ran a multivariate regression model based on the dependent variable "out- 
come of case is p-win" versus "all other outcomes."162 We included as independent dummy variables "Solicitor General as party" (either petitioner or respondent), "Solicitor General as amicus" (either for petitioner or for respondent), and the six different disparity possibilities tracked in Figures 11 and 12.

Our findings are quite consistent with Figures 11 and 12: in terms of impact on p-win rates, disparities of $1-0-0$ and $2-0-0$ are statistically significant, as are disparities of 0-1-0 and 0-2-0. The third column in both Figures, however, showing disparities at levels of three or more briefs filed for either side, is not statistically significant (at the $p<.05$ level) within the model. ${ }^{163}$

Of particular interest to us is the robustness of the different case variables in altering the odds of a p-win outcome, controlling for other variables. To facilitate this assessment, we included odds ratios for a $p$ win outcome. These ratios show that if the Solicitor General is present as petitioner, all other factors being equal, the odds of a $p$-win are effectively doubled. If the Solicitor General is present as respondent, all other factors being equal, the odds of a p-win are effectively reduced by roughly half. We found less robust effects for the disparity figures: $1-0-0$ and $2-0-0$ cases with the Solicitor General filtered out as amicus increase the odds of a $p$-win by roughly $27 \%$ and $50 \%$, respectively; 0-1-0 cases and 0-2-0 cases decrease the odds of a p-win outcome by roughly $20 \%$ and $45 \% .^{164}$

We should note an important caveat here. When we expanded our regression model to include dummy variables for each of the institutional litigants, and then excluded the amicus briefs filed by these institutional litigants from the disparity dummy variables, the disparity variables were no longer statistically significant. ${ }^{165}$ This could mean that with the institutional filers excluded, the numbers of cases reflected in the disparity variables were decreased to the point where the variance among them was too great to generate significant results. Alternatively, it could mean that what appears to be an impact from disparity of support is actually an impact from support by an institutional litigant.

${ }^{162}$ A description of our logit regression model and more detailed results are set forth in Appendix C, infra.

${ }^{163}$ See infra Appendix C, tbl.I.

164 See id.

165 See id. at tbl.II. 
In sum, by focusing on different subsets of our database in our analysis, we uncovered some evidence that disparities of amicus support may have an impact on the outcomes reached by the Supreme Court. The effect of disparities of one or two amicus briefs on success rates for petitioner is not strong enough to overcome the heightened probability of success enjoyed by the Solicitor General as amicus and as a party. Consequently, the effect can only be seen by comparing means across subsets of data that exclude the Solicitor General. Moreover, this effect appears only when there are either one or two briefs in support of one party and no briefs in support of the other. For some reason, the effect largely disappears when there are three or more briefs in support of one party and no briefs in support of the other. Finally, even the small effect of disparities of one or two briefs loses statistical significance when we analyze these disparities as independent variables in a regression model that includes all four institutional litigants.

\section{The Impact of Amicus Brief Quality}

By far the most difficult model to test quantitatively is the legal model, which predicts that the Court is influenced by briefs that present especially valued information but not by briefs that are merely repetitive of the parties' briefs. Because reading and assessing the quality of more than 12,000 individual amicus briefs was a task far beyond our endurance, we had to come up with a proxy for briefs that contain information valued highly by the Court. We adopted three approaches. First, we inquired whether cases with an amicus brief from one of our institutional litigants had different success rates from those supported by "ordinary" amicus briefs. Second, we examined the success rates of amici whose briefs the Court or an individual Justice explicitly relied upon through citation. Third, we considered whether briefs filed by more experienced Supreme Court litigators enjoy greater success than briefs filed by less experienced litigators.

\section{Success Rates of Institutional Litigants}

We examined the success rates of the Solicitor General, the ACLU, the AFL-CIO, and the States over each of the five decades. We reasoned that the first three of these entities are good proxies for high-quality amicus briefs, i.e., those containing valued information. Not only has each of these entities filed numerous amicus briefs in all 
five decades, but each employs or retains counsel with substantial Supreme Court litigation experience. The Solicitor General's office has been widely praised by the Justices and others for the consistent quality of its briefs. ${ }^{166}$ Similarly, the national offices of both the ACLU and the AFL-CIO are widely regarded by knowledgeable Supreme Court observers as consistently producing briefs of superior quality. ${ }^{167}$ Only the States as institutional litigants represent a problematic proxy for quality. The offices of state attorneys general vary widely in terms of the skill of the lawyers they employ and the degree of experience they bring to the task of filing Supreme Court briefs. ${ }^{168}$ On balance, therefore, the overall quality of the States' filings should be closer to "average" rather than high quality.

${ }^{166}$ See, e.g., SALOKAR, supra note 105, at 33-34 (praising the Solicitor General's office for the high quality of its lawyers and the "accuracy and reliability of its briefs"); LINCOLN CAPLAN, THE TENTH JUSTICE 19 (1987) (discussing the tradition of highquality submissions from the Solicitor General's office).

See, e.g., Epstein, supra note 42, at 689 (noting that the ACLU "is a well-known repeat player with substantial resources and great expertise in reproductive freedom litigation"); Morriss, supra note 80 , at $879-86$ (commenting that the AFL-CIO made "significant legal arguments" in its amicus briefs in two recent Title VII cases before the Supreme Court). It should be emphasized, with regard to the ACLU and AFLCIO, that we restricted ourselves to amicus briefs filed by the national organizations thus named and therefore did not include filings by local affiliates or chapters or by constituent unions. These are entities separate from the AFL-CIO and the ACLU and have different (and almost always less experienced) counsel. For examples of amicus briefs excluded on this principle from being counted as an "ACLU" or "AFL-CIO" brief, see Cohen v. California, 403 U.S. 15, 15 (1971) (brief filed by ACLU of Northern California); Youngstown Sheet $\mathcal{E}$ Tube Co. v. Sawyer, 343 U.S. 579, 595 (1952) (brief filed by United Steelworkers of America, CIO); and International Brotherhood of Electrical Workers v. NLRB, 341 U.S. 694, 695 (1951) (brief filed by United Brotherhood of Carpenters \& Joiners, AFL). For cases litigated prior to the 1955 merger of the AFL and CIO, we tracked whether either entity filed an amicus brief.

${ }_{169}$ See PERRY, supra note 81, at 127 (citing interviews with Justices and former clerks for the proposition that attorneys for state governments are generally ineffective); see also Lee Epstein \& Karen O'Connor, States and the U.S. Supreme Court: An. Examination of Litigation Outcomes, 69 Soc. SCI. Q. 660, 665-66 (1988) (exploring variables such as progressiveness of individual state policies and state governmental litigation apparatuses to explain the differences in state litigation success). 
Among the three institutional litigants with experienced Supreme Court lawyers, the largest deviation from the benchmark success rates occurred in cases where the Solicitor General appeared as amicus. As shown in Figure 13, the p-win rate in cases in which the Solicitor General appears as an amicus for the petitioner increases substantially beyond the mean rates in each decade. Indeed, the average differential between $p$-win rates in cases where the Solicitor General appears as amicus and the benchmark rate is just under $17 \%$, and in no decade is the Solicitor General's presence as amicus supporting petitioner marked by less than a $12 \%$ increase in the p-win rate.

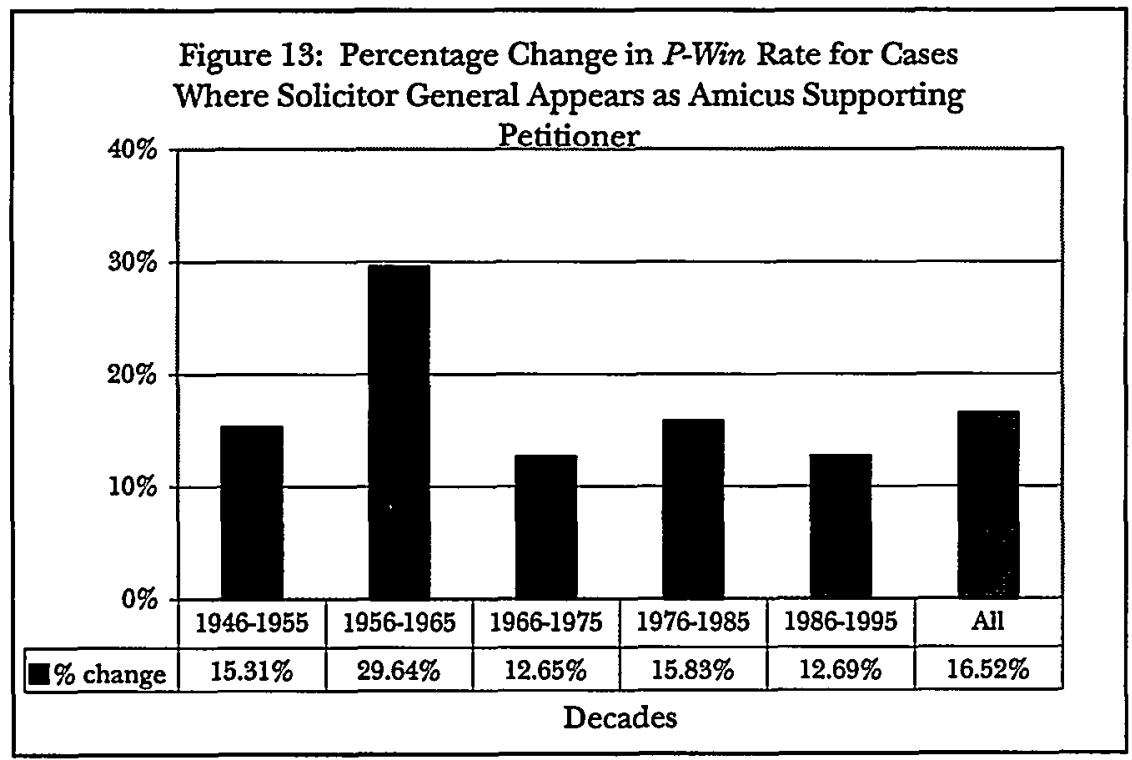

\begin{tabular}{|l|c|c|c|c|c|c|}
\hline Dala UnderlyingFigure 13 & $1946-1955$ & $1956-1965$ & $1966-1975$ & $1976-1985$ & $1986-1995$ & $A l l$ \\
\hline Number of Cases & 47 & 80 & 92 & 167 & 192 & 578 \\
\hline
\end{tabular}


As shown in Figure 14, there is a corresponding decrease in p-win rates in cases in which the Solicitor General appears as an amicus supporting the respondent. The first two decades of our study may be disregarded for these purposes because of the low numbers of cases (although their percentages are nonetheless not outliers). In each subsequent decade, however, the p-win rate decreases by at least $21 \%$ where the Solicitor General took the respondent's side as amicus. Indeed, the average decrease in the $p$-win rate was almost $26 \%$ over all cases. This is the single most pronounced deviation from benchmark success rates we uncovered in our study.

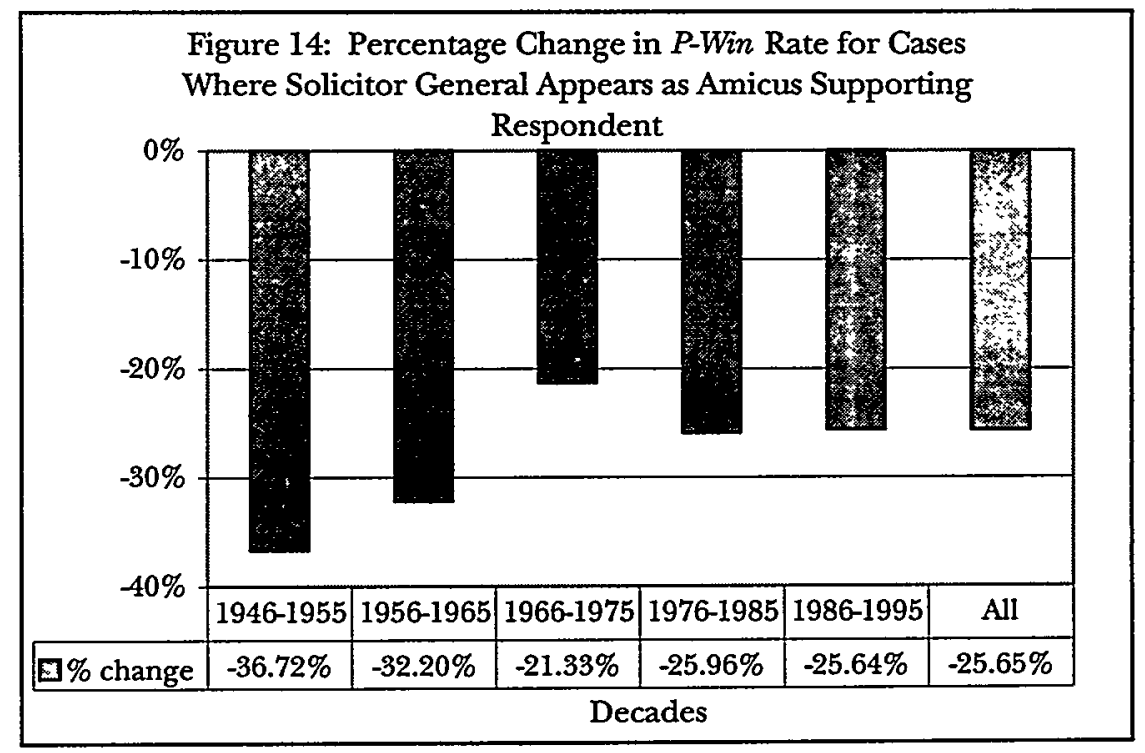

\begin{tabular}{|l|c|c|c|c|c|c|}
\hline Data UnderlyingFigure 14 & $1946-1955$ & $1956-1965$ & $1966-1975$ & $1976-1985$ & $1986-1995$ & All \\
\hline Number of Cases & 11 & 17 & 38 & 110 & 120 & 296 \\
\hline
\end{tabular}


The changes from benchmark p-win rates are substantially less pronounced when we look at cases in which the ACLU or AFL-CIO appeared as an amicus. Indeed, the changes in some instances are not in the direction of the side supported by the institutional litigant. As shown by Figure 15, the ACLU has achieved fluctuating, but usually favorable, rates of success relative to the benchmark when it files briefs supporting the petitioner. In two of the decades, the p-win rate when the ACLU filed is higher than the benchmark rate by more than $10 \%$. For the 1966-1975 decade, however, the p-win rate when the petitioner was supported by the ACLU as amicus is actually lower than the benchmark by nearly $8 \%$. For the entire fifty-year period, the ACLU achieved a positive differential of just under $6 \%$ in cases supporting petitioner.

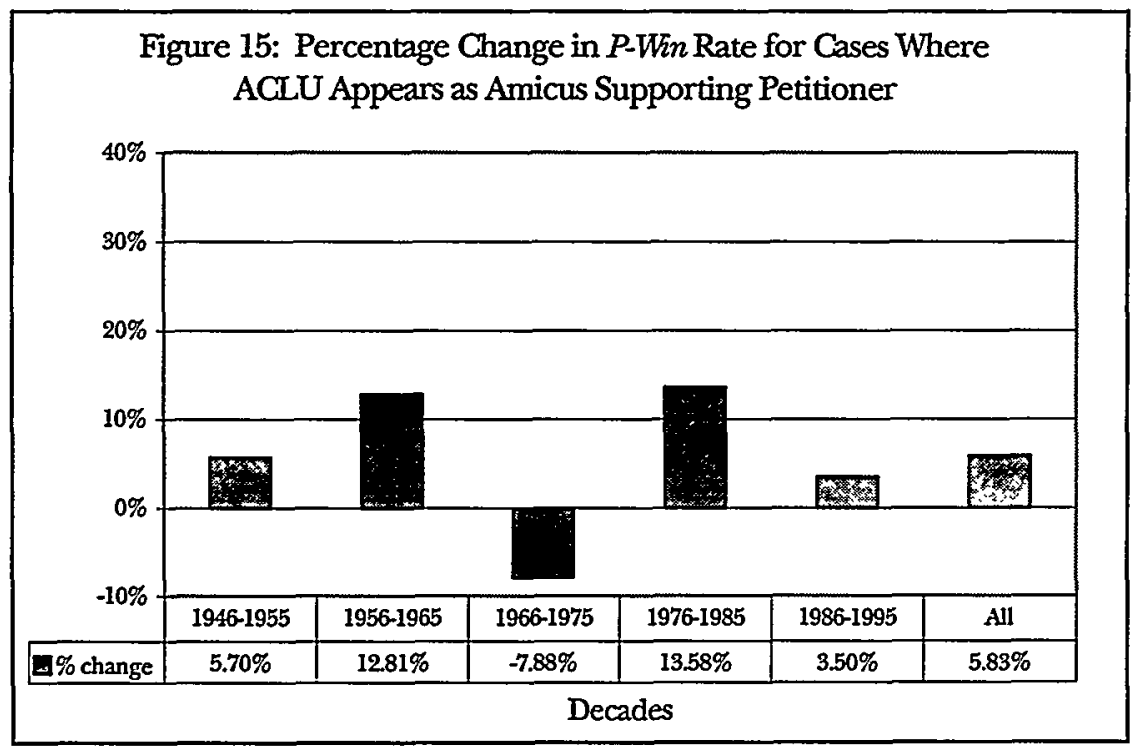

\begin{tabular}{|l|c|c|c|c|c|c|}
\hline Data Underlying Figure 15 & $1946-1955$ & $1956-1965$ & $1966-1975$ & $1976-1985$ & $1986-1995$ & All \\
\hline Number of Cases & 33 & 43 & 45 & 56 & 73 & 250 \\
\hline
\end{tabular}


Contrary to the usual pattern in which petitioner success rates decline with amicus support for respondent, the results where the ACLU appears as an amicus for the respondent are much less impressive. As reflected in Figure 16, in the three decades where there are reasonable numbers of cases, the ACLU achieved at best only modest differential rates of success, and, in one decade (1986-1995), it underperformed the benchmark rate of success for respondents.

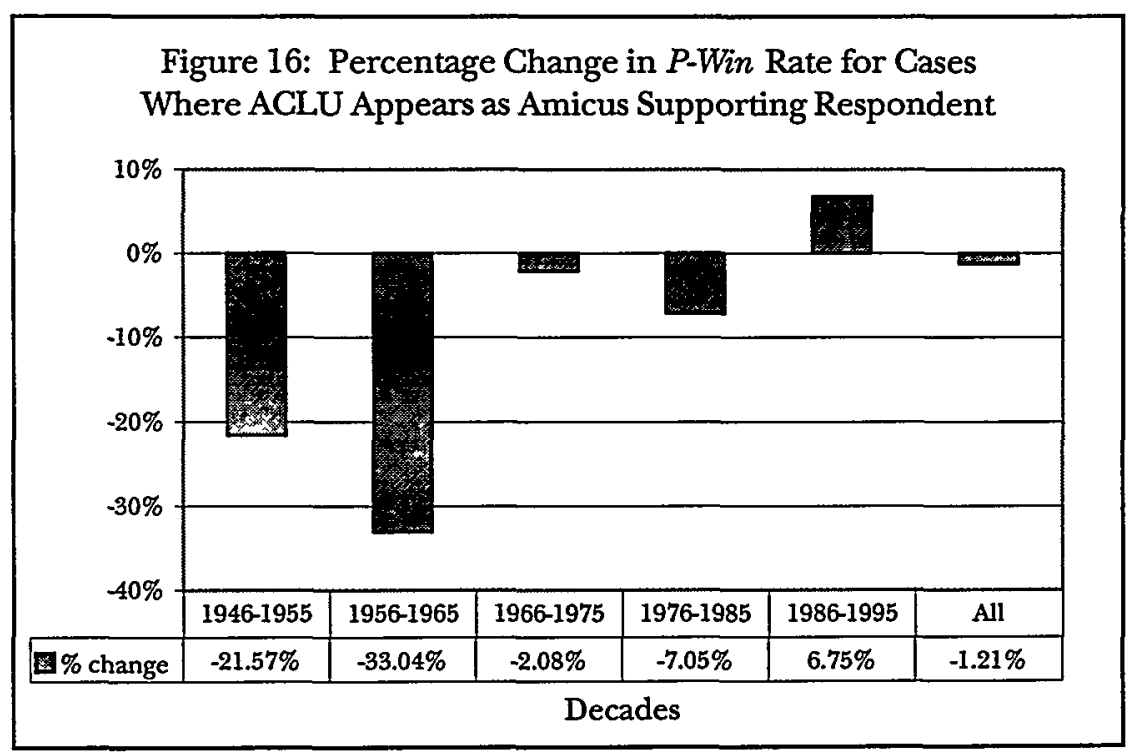

\begin{tabular}{|l|c|c|c|c|c|c|}
\hline Data UnderlyingFigure I6 & $1946-1955$ & $1956-1965$ & $1966-1975$ & $1976-1985$ & $1986-1995$ & All \\
\hline Number of Cases & 3 & 7 & 44 & 103 & 94 & 251 \\
\hline
\end{tabular}


The cases in which the AFL-CIO participated as an amicus provide yet a third pattern. As set forth in Figure 17, the AFL-CIO's support of petitioner produces inconsistent results. After achieving less success than the benchmark rate in the first decade, the AFL-CIO achieves an increase in p-win rates relative to the benchmark in the second and third decades, but then falls back into negative territory in the last two decades. Overall, the AFL-CIO shows a modest positive differential of less than $3 \%$. The underlying pool of cases is small in each instance (only 1976-1985 has more than thirty cases).

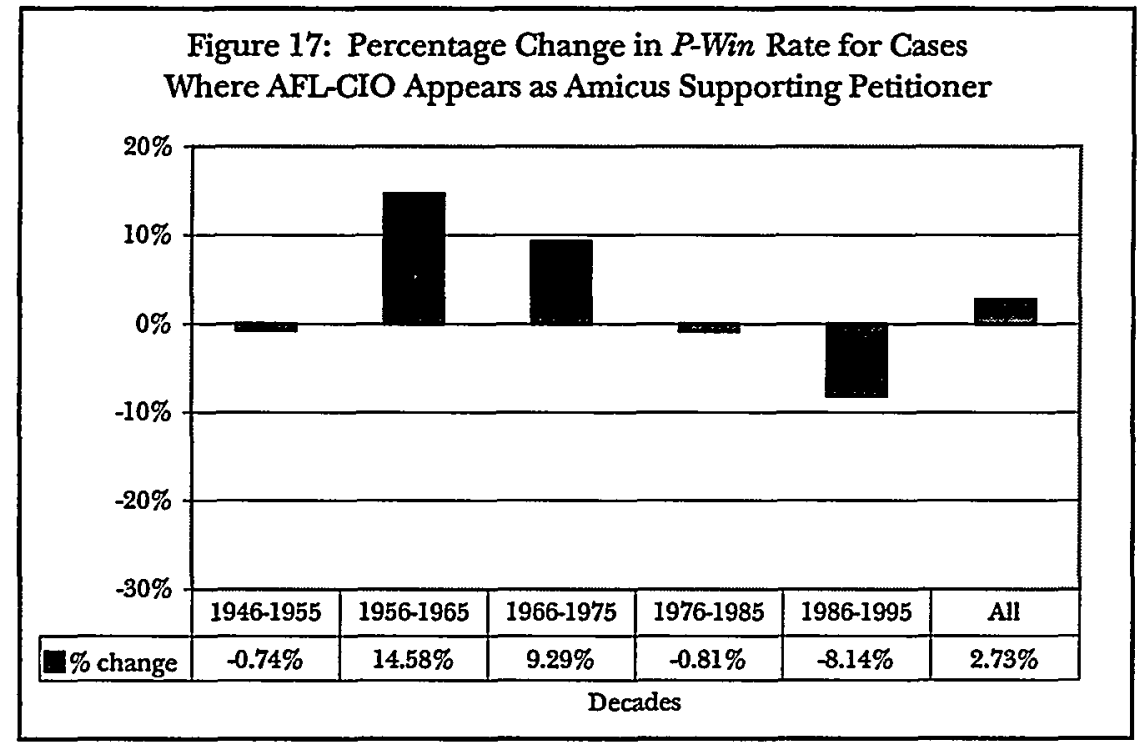

Data Underlying Figure 17 \begin{tabular}{|l|l|l|l|l|l|}
\hline $1946-1955$ & $1956-1965$ & $1966-1975$ & $1976-1985$ & $1986-1995$ & All \\
\hline
\end{tabular}

21

22

33

20 120 
When the AFL-CIO appears as an amicus supporting the respondent, however, we see our usual pattern of higher success rates again. As Figure 18 suggests, differential success is obtained in the last two decades. No clear pattern can be discerned in the first three decades, where the numbers of briefs are small. Overall, the AFL-CIO exhibits a substantial differential some $14 \%$ better than the benchmark rate.

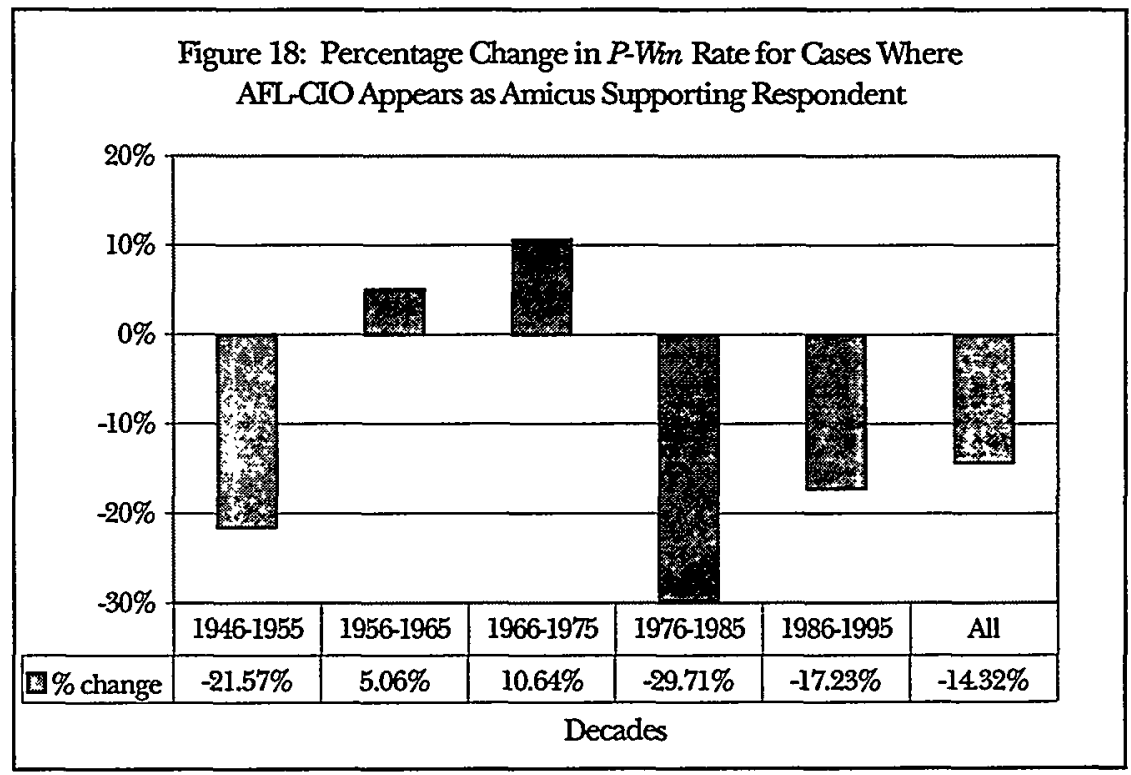

\begin{tabular}{|l|c|c|c|c|c|c|}
\hline Data Underlying Figure 18 & $1946-1955$ & $1956-1965$ & $1966-1975$ & $1976-1985$ & $1986-1995$ & All \\
\hline Number of Cases & 6 & 3 & 27 & 41 & 44 & 121 \\
\hline
\end{tabular}


Finally, to provide a source of comparison, it is instructive to consider the success of the States as amicus filers. When the States file amicus briefs supporting the petitioner, and no State appears as a different kind of amicus, they show modest success overall, securing a $p$ win rate about $5 \%$ higher than the benchmark rate. When we break the results down by decade, Figure 19 reveals that during the last three decades, when the States were filing significant numbers of briefs supporting petitioners, they achieved small and declining success.

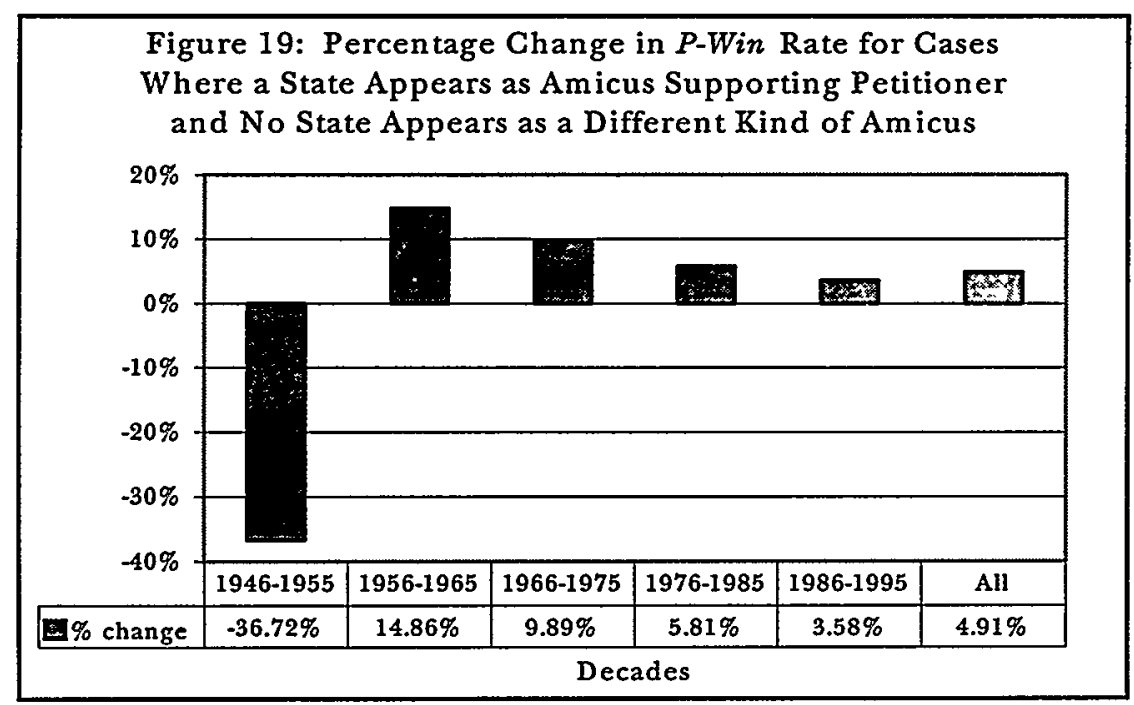

Data Underlying Figure 19 Number of Cases \begin{tabular}{|l|l|l|l|l|l|}
\hline $1946-1955$ & $1956-1965$ & $1966-1975$ & $1976-1985$ & $1986-1995$ & All \\
\hline
\end{tabular}

\begin{tabular}{|l|l|l|l|l|l|}
11 & 17 & 45 & 119 & 128 & 320 \\
\hline
\end{tabular}


The States have been moderately more active, and successful, on the respondent's side. As shown in Figure 20, measured over all five decades the respondents supported by States have bettered the benchmark rate by nearly $9 \%$. This robust number is driven by the large numbers of cases in the last two decades.

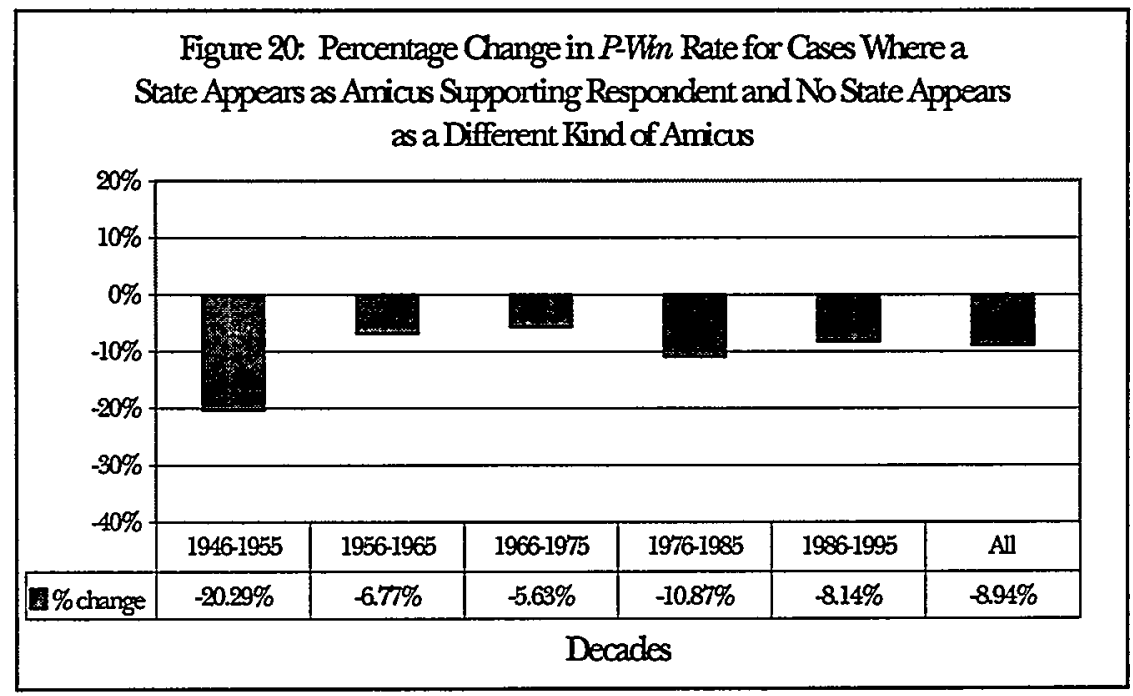

Data Underlying Figure 20 |1946-1955|1956-1965|1966-1975 $1976-1985|1986-1995|$ All Number of Cases

\begin{tabular}{|c|c|c|c|c|c|}
\hline 26 & 31 & 64 & 91 & 146 & 358 \\
\hline
\end{tabular}

In order to gain a clearer sense of the relative power of the different institutional litigants, we ran a multivariate regression incorporating variables for all four institutional litigants as well as variables similar to those used in our disparity studies. We also included new variables for amicus briefs cited by the Court and those filed by experienced lawyers. ${ }^{169}$ The results of this regression, set forth in more detail in Appendix C, largely confirm what our figures based on compared means suggest. The Solicitor General's amicus briefs have a statistically significant impact on outcomes (all other variables held constant) for both the petitioner's and respondent's side. The ACLU's briefs have a statistically significant impact on the petitioner's side but not on the respondent's side. Conversely, the AFL-CIO's briefs have a statistically significant impact on the respondent's side but not the petitioner's. The States have a statistically significant im- 
pact only on the respondent's side as well. ${ }^{170}$

Our next step was to determine to what extent the statistically significant variables in the model actually altered the likelihood of a $p$ win outcome across all cases. To assess this, we looked at the odds ratios produced by each variable in the model and determined how it would influence the odds of a p-win outcome. The effect of the Solicitor General as amicus outweighed all other institutional litigants in this regard; the Solicitor General increased the odds of a p-win outcome by roughly double when filing as amicus on behalf of the petitioner, and decreased the odds by nearly $50 \%$ when filing on behalf of the respondent. The ACLU had a powerful impact when filing on behalf of petitioner, increasing the odds of a $p$-win by about $70 \%$, but did not display a predictable or stable pattern of increasing or decreasing the odds when filing on behalf of respondent. The AFL-CIO decreased the odds of a p-win by about $40 \%$ when filing on behalf of respondent. The States displayed a similar effect filing as amici in support of respondents, decreasing the odds by about $35 \%{ }^{17}$

\section{Success Rates of Cited Briefs}

We also decided to use as a proxy for quality the amicus briefs that members of the Court cited in their opinions. We reasoned that a cited brief is one that provided at least some valued information to the Court beyond that supplied by the briefs of the parties. Thus, briefs that are cited may be regarded as "high quality" in the relevant sense of supplying valued and nonrepetitive information. Of course, one must exercise caution here. It is possible that cited amicus briefs play no role in the decision-making process, and are mined by the Justices (or their clerks) only at the opinion-writing stage. Nevertheless, it is plausible to think that cited briefs are more valuable briefs, and if the legal model is correct, we should find that more valuable briefs will, over large numbers of cases, prove to be more successful.

The characteristics of our database made it possible to identify cited briefs that supported the decision of the Court only in those cases that contained only one cited amicus brief. ${ }^{172}$ Of the 758 major-

${ }^{170}$ See infra Appendix C, tbl.II (setting forth the results of the regression used in conjunction with Figures 13-22).

${ }_{171}$ See id. (containing relevant variables).

172 This is because our database tracks whether or not the Court referred to zero, one, or more than one amicus brief, and further tracks whether the Court ruled in favor of any of the amici to which it referred. (The former aspect of the database was necessary because, in numerous cases where the Court refers to more than one amicus, 
ity or plurality opinions citing amicus briefs, 548 cited only one amicus brief. Of these 548 opinions, we excluded 121 of them because it was not clear whether the Court ruled in favor of the party that filed the amicus brief the Court cited. ${ }^{173}$ Of the remaining 427 cases, in 240 the cited brief was filed on the petitioner's side, and in 187 the cited brief was filed on the respondent's side. With this information, and knowing whether the Court ruled for the petitioner or the respondent, we were able to determine success rates for cited briefs supporting petitioners and for cited briefs supporting respondents. ${ }^{174}$

Our results, as set forth in Figure 21 below, provide no support for the proposition that cited briefs enjoy greater success than noncited amicus briefs. The cases including a cited brief supporting petitioner have a $p$-win rate less than $2 \%$ above the benchmark. The cases including a cited brief supporting respondent have a $p$-win rate about $7 \%$ below the benchmark. These success rates are very close to those of the "average" amicus filer over our entire set of cases, which show an increase in the p-win rate of less than $1 \%$ for briefs supporting petitioner and a decrease in the $p$-win rate of about $7 \%$ for briefs supporting respondent. ${ }^{175}$ Thus, the success rates of the cited amicus filers appear to parallel the success rates of amicus filers overall. In any event, our regression model indicates that these results are not statistically significant predictors of petitioner success. ${ }^{176}$

the Court's writing style makes it impossible to determine precisely how many amici, with how many separate briefs, the Court is referring to. For example, the Court might write, "Petitioner and several of its amici argue ....") The combination of these two columns in our database, together with the column tracking whether or not the outcome in each case was a p-win, p-loss, or mixed result, meant that we could track whether the Court ruled in favor of an amicus to which it referred, and whether that amicus supported petitioner or respondent, only where it referred to only oneamicus brief.

${ }^{733}$ The number of cases where it was not clear whether the Court ruled for the one amicus brief that it cited-22.08\%, or just more than one-fifth of these cases-is high because the Court either cited an "other" amicus brief (we did not track in the citation study itself whether the brief cited was for the petitioner, was for the respondent, or was an "other" brief) or reached a mixed result. See infra Appendix B at notes 15-27 and accompanying text (defining "other" briefs and "mixed result" cases).

174 Since every case in this particular subset resulted in either a p-uin or a $p$-loss, it was necessary to recompute the benchmark rates as if the mixed resull cases did not exist. As recomputed, the $p$-win rate is $61.87 \%$.

${ }^{175}$ See supra Figures $7 \& 8$.

${ }^{176}$ See infra Appendix C, tbl.II. 
Figure 21: Percentage Change in $P-W n$ Rate for Certain Cases Where the Court Cites One Amicus Brief

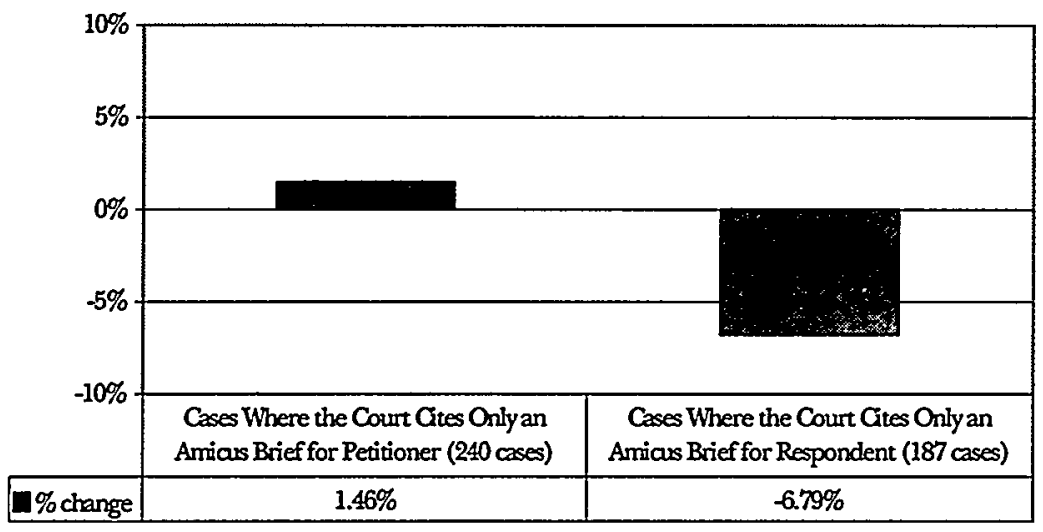

\section{Success Rates of Briefs Filed By More Experienced Lawyers}

In a final effort to measure the effect of high-quality amicus briefs, we undertook to differentiate among amicus briefs based on the degree of Supreme Court experience of the lawyers who wrote the briefs. Kevin McGuire, a political scientist, has authored several studies examining whether more experienced lawyers enjoy greater success in the Supreme Court than less experienced lawyers. ${ }^{177}$ McGuire reasons that experienced lawyers are more likely to frame issues and arguments in a way that is persuasive to the Court, and are likely to have greater credibility with the Court. Hence, he predicts, their submissions should have a greater impact on the decisional process, which should be reflected in greater success before the Court. ${ }^{178}$

${ }^{177}$ See KEVIN T. MCGUIRE, THE SUPREME COURT BAR 171-99 (1993) [hereinafter MCGUIRE, THE SUPREME COURT BAR] (analyzing the effect of the involvement of experienced Supreme Court counsel on the Court's case selection and judgments); McGuire, supra note 161, at 509-11 (weighing the importance of experience in effective Supreme Court advocacy). See generally McGuire, supra note 97 (arguing generally that parties with more litigation experience in the Supreme Court are more likely to succeed).

${ }^{178}$ See McGuire, supra note 161 , at 510 (referring to empirical data to support the contention that litigators who reduce the Justices' information costs are likely to be favored). 
McGuire's studies generally measure advocate experience by counting the number of times a lawyer is recorded as having entered an appearance at either oral argument or on the briefs of the parties in cases in the Supreme Court. He then determines which side's advocate is more experienced. Using this method, McGuire shows that more experienced lawyers are more successful at getting certiorari petitions granted, ${ }^{179}$ and are more likely to prevail on the merits. ${ }^{180}$ Most recently, he has argued that the success rate of the Solicitor General is almost entirely attributable to the greater experience of the lawyers in the Solicitor General's office relative to their opponents in most cases. $^{181}$

We sought to replicate McGuire's method in the context of assessing the influence of amicus briefs. Because it would be conceptually difficult to rank the experience of the lawyers in cases involving multiple amicus briefs, we limited our consideration to those cases in which one amicus brief was filed in support of petitioner and one in support of respondent (1-1-0 cases). In addition, we excluded cases with amicus briefs filed by the Solicitor General and cases with amicus briefs filed by a State. Within the remaining set of cases, we used computer research methods to determine how many times each member of the Supreme Court bar who appeared on each amicus brief had previously appeared on behalf of a party or amicus before the Supreme Court. Following McGuire's method, the lawyer with the highest number of appearances in each case was deemed the more experienced. We then computed the change in p-win rates where the petitioner's amicus was more experienced than the respondent's, and where the respondent's amicus was more experienced than petitioner's. As a benchmark, we used the p-win rate in all 1-1-0 cases excluding the Solicitor General and the States as amici.

The results are summarized in Figure 22. As can be seen, amicus briefs filed by more experienced lawyers supporting petitioners experienced a $p$-win rate about $8 \%$ higher than the benchmark rate, and amicus briefs filed by more experienced lawyers supporting respondents experienced a p-win rate nearly $10 \%$ lower than the benchmark rate. However, the numbers of cases in both of these categories are fairly small (56 cases and 64 cases, respectively), and these results were

179 See MCGUIRE, THE SUPREME COURT BAR, supra note 177, at 184.

180

See McGuire, supra note 97, at 194.

${ }^{181}$ See McGuire, supra note 161, at 513-14. 
not statistically significant in our regression model. ${ }^{182}$ Thus, although our results are suggestive and are generally consistent with McGuire's findings about the impact of experienced lawyers, they must be used with caution.

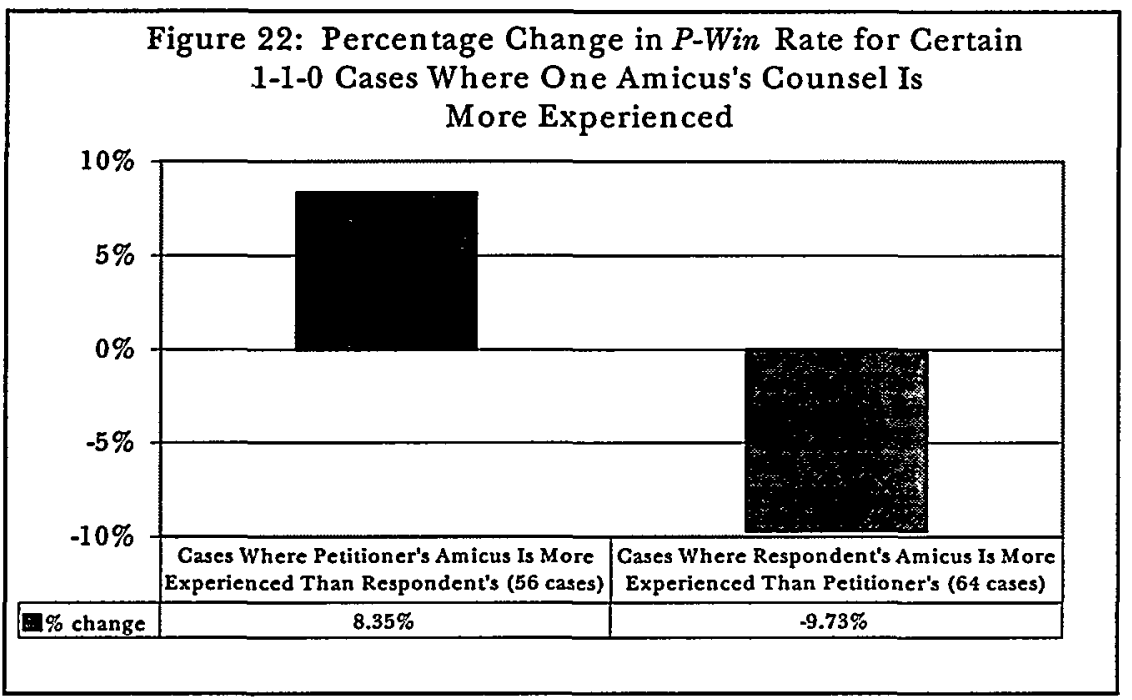

\section{Interpretation of Results}

Overall, our results arguably provide some support for each of the models of judging set forth in Part IV. A proponent of the attitudinal model can point to the lack of impact from amicus filers in general (at least on the petitioner's side), the failure to find that the ACLU and the AFL-CIO enjoy consistent success even though they file highquality briefs, and the failure to find that cited amicus briefs are any more likely to support prevailing parties than those that are not cited. The pronounced influence of the Solicitor General and the milder influence of the States might be explained away by the attitudinalist as ad hoc exceptions to the model. ${ }^{183}$

A proponent of the strategic actor variation on the attitudinal

182 See infra Appendix C, tbl.II (setting forth in more detail the results of the regression used in conjunction with Figure 22).

${ }^{183}$ Segal and Spaeth in fact have acknowledged that the Solicitor General has an independent influence on outcomes beyond what would be predicted under the attitudinal model, and treat the Solicitor General as an ad hoc exception. See SEGAL \& SPAETH, supra note 14, at 237-38. 
model would stress the consistent findings suggesting the high success rate of the Solicitor General. Since the executive branch is critical to the implementation of the Court's policy preferences, it is not surprising to find that the Court apparently pays careful attention to the positions of the Solicitor General. Likewise, the States are important political actors and play a role in implementing the Court's decisions, so it is consistent with the strategic actor model that they too should achieve a measure of success as amici.

The interest group theory also finds something to point to in support of its contentions that the Justices decide cases so as to maximize their own reputations or the public standing of the Court as an institution. Disparities of support by amicus filers appear to matter, in that parties supported by one or two amicus briefs when there is no brief filed on the opposing side experience greater rates of success, at least once we control for the influence of the Solicitor General. The interest group theorist might even offer an explanation of the success of the Solicitor General, to the effect that the executive branch pays close attention to the views of the public, and hence its legal representative before the Court is likely to take positions that are popular with the general public. The Court, the interest group theorist might argue, is aware of the executive's desire to track public opinion, and so the Court follows the lead of the Solicitor General in order to assure that it does not run afoul of public opinion.

Notwithstanding these arguments in support of other theories, on the whole we interpret our results as providing the most support for the legal model. We reach this conclusion for four reasons.

First, throughout all our results we find a fairly consistent pattern in which amicus briefs supporting respondents show more success relative to the benchmarks than do amicus briefs supporting petitioners. This is true of the data concerning amicus filers in general; ${ }^{184}$ the data on the impact of disparities when the Solicitor General is excluded; ${ }^{185}$ the data on the success rates of the Solicitor General, ${ }^{186}$ the AFL-CIO, ${ }^{187}$ and the States; ${ }^{188}$ the data on the success of cited briefs; ${ }^{189}$ and the data on experienced lawyers. ${ }^{190}$

\footnotetext{
184 See supra Figures $7 \& 8$.

185 See supra Figures 11 \& 12.

186 See supra Figures $13 \& 14$

${ }^{187}$ See supra Figures $17 \& 18$.

188 See supra Figures $19 \& 20$.

189 See supra Figure 21.

190 See supra Figure 22.
} 
Why might amicus filers supporting respondents achieve more success than filers supporting petitioners? The explanation may be that petitioners typically must be represented by able counsel in order to convince the Court to grant review. The Court grants certiorari in only about $4 \%$ of all cases in which it is sought. ${ }^{191}$ Thus, there is a strong presumption against review, and a petitioner's counsel must carry a heavy burden in persuading the Court to hear her case in preference to thousands of others. The lawyer who can carry this burden must typically be highly skilled. ${ }^{192}$ In contrast, respondents obviously do not have to be represented by able counsel in order to have the Court grant review; indeed, the Court is more likely to grant review if the respondent is not represented by able counsel who can distinguish circuit conflicts and offer prudential reasons why review should be denied. ${ }^{193}$

If it is true that petitioners are, on averàge, represented by more able counsel than respondents, then respondents may obtain a greater boost from the assistance of an amicus brief. In effect, an amicus brief may function in significant numbers of cases as a "stand in" for a highquality brief on the merits, and respondents may benefit more than petitioners from such briefs. This explanation, if valid, would tend to support the legal model because it suggests that amicus briefs have an impact insofar as they provide relevant legal and background information missing from the party's brief on the merits.

Second, there is the intriguing feature of the disparity studies that shows that success rates exceed the benchmark with one or two briefs filed in support of a party and no amicus briefs on the other side, but fall back toward the benchmark with three or more briefs filed in support of a party and no briefs on the other side. This result is rather puzzling and, given that it is not significant under our regression models, may reflect other factors which we were not able to test. Nonetheless, there are two possible explanations, both somewhat supportive of the legal model.

191 See EPSTEIN ET AL., supra note 21, at 82-83 (listing rates at which Court granted petitions for certiorari during the 1970-1995 Supreme Court Terms).

${ }^{192}$ This proposition, of course, is not always true. There will be instances where cases present such square circuit conflicts or issues of such clear national importance that any lawyer could secure review. We are speaking of the general case.

${ }^{193}$ Of course, respondent's counsel was skilled enough to prevail in the court below. But Supreme Court advocacy is a specialized discipline. Often petitioners who succeed in obtaining a grant of review will have switched to specialized Supreme Court lawyers; the respondent who prevailed below may be less inclined to shop for new counsel once the case moves to the Supreme Court. 
One possible explanation is that the pool of cases with only one or two amicus briefs and the pool of cases with larger numbers of amicus briefs reflect different sorts of controversies. The pool with small numbers of briefs may consist largely of "low profile" controversies that turn on questions of statutory interpretation or procedure. Legal doctrine may play a relatively large role in the resolution of these sorts of controversies, with the result that one or two amicus briefs filed on one side and none on the other will have a demonstrable effect on outcomes-especially if the Solicitor General is out of the picture. In contrast, the pool of cases that contains three or more amicus briefs may include a much higher percentage of "high profile" cases. In these sorts of cases, legal doctrine may play a less significant role, and judicial behavior may more closely approximate what the attitudinal model depicts. If so, this would account for the puzzle that amicus briefs evidently have much less impact on outcomes in these cases. All this is quite speculative, obviously, and clearly additional research is warranted in an effort to determine whether amicus briefs play a different role in low-profile as opposed to high-profile cases.

An alternative explanation is that it very rarely takes more than two amicus briefs to supply whatever additional information is valued to the Court under the legal model. The Court may view three or more amicus briefs as repetitious or as an annoying effort to "lobby" the Court, producing counterproductive results. We regard this explanation as less plausible than the first explanation. The Court's most likely response to repetitive amicus briefs is to ignore them, not to punish the party they support.

Third, there is the dramatic success of the Solicitor General as an amicus filer. As we have seen, there are a variety of explanations for the Solicitor General's success with amicus briefs, including the possibility that the Justices defer to the views of the Solicitor General for strategic reasons and the possibility that the Justices defer because they assume that the executive branch will tend to endorse politically popular positions. But these explanations are weak. Often the Solicitor General files amicus briefs at the invitation of the Court, or on issues as to which the executive branch previously has had no views or only mild preferences. In addition, most of the cases in which the Solicitor General files amicus briefs involve issues as to which it is unclear what the public's preferences might be. Both the Justices themselves and close observers of the Solicitor General's office attribute the high rate of success to the Solicitor General's reputation for objectivity 
in accurately stating the law. ${ }^{194}$ It is reasonable to assume that this is at least part of the explanation for the Solicitor General's remarkable success as an amicus filer, and this too tends to support the legal model.

Fourth, our other attempts to measure the impact of high-quality amicus briefs, while admittedly not always supportive of the legal model and often not producing statistically significant results, provide modest support for the legal model. Although the ACLU and the AFL-CIO, two other filers of high-quality briefs, do not consistently beat benchmark rates of success, they have been successful more than the average amicus filer. Our study of the impact of amicus briefs filed by experienced lawyers also provides suggestive support for the legal model.

In arguing that the legal model is best supported by our findings, we do not suggest that the legal model provides the sole explanation for Supreme Court decisions, or that our data do not also provide some support for the rival models. We do believe, however, that our study provides evidence that amicus briefs that speak to the requirements of the law exert some influence on the outcomes reached by the Court. In other words, law matters, and because law matters, amicus briefs that speak to the requirements of the law matter.

\section{RECONSIDERING THE RISING TIDE OF AMICUS BRIEFS}

Does our study of the impact of amicus briefs on the outcomes reached by the Supreme Court explain the remarkable proliferation of such briefs in the last half century? We think it provides some missing pieces of the picture. But it is doubtful that the impact of briefs on outcomes is the sole driving force behind this phenomenon. Multiple factors must be at work, some of which are not well understood and will require further research to comprehend fully.

As noted in Part II, the Court's adoption of an open door policy toward the filing of amicus briefs provides one part of the explanation for the surge in amicus filings in the last three decades. The knowledge that any group can file an amicus brief without risk of rejection increases the benefits to interested organizations of seeking to file such a brief, whatever those benefits might be. This is especially so relative to the previous state of affairs, marked by uncertainty as to

194 See generally sources cited supra note 161 (examining the success of the Solicitor General before the Court). 
whether such a brief would be accepted. Thus, the Court's gradual embrace of the open door policy, starting in the late 1950s, probably accounts for some of the increase. Still, as we explained in Part II, the continued proliferation of amicus briefs into the 1980s and 1990s is difficult to attribute to the open door policy alone, which has now been firmly in place for several decades.

An awareness that amicus briefs can influence outcomes, even if that understanding is only intuitive among Supreme Court litigators, may also account in part for the increase in filings. To be sure, our study reveals no evidence that would suggest that amicus briefs in general have had an increasing impact on outcomes over the fifty years of our study. The various measures we have developed of success rates over time suggest at most a constant or perhaps downward trend in terms of success rates over the period of our study. ${ }^{155}$ Nevertheless, it may be that perceptions of impact have grown as anecdotal examples of influence have multiplied. With respect to the amicus filings of the Solicitor General, for example, our study shows that such briefs are associated on average with a $17 \%$ increase in petitioner success and a $26 \%$ increase in respondent success. If the Justice Department has become aware of this remarkable record, even if only impressionistically, it would stand to reason that the Department would make increasing use of Solicitor General amicus briefs in order to influence Supreme Court decision making. In fact, we find that the Solicitor General's office has dramatically increased its amicus filings during the period of our study. ${ }^{196}$ Similar points could be made, albeit with more qualifications, about the States, the ACLU, and the AFLCIO.

With respect to other filers, however, it is far from clear that impact on outcomes provides much, if any, explanation for the popularity of amicus participation. The average filer supporting petitioners, in particular, cannot be shown to have any impact on outcomes. ${ }^{197} \mathrm{We}$

${ }^{195}$ See supra Figure 7 (charting the success rate of all amici supporting petitioner); supra Figure 8 (same for all amici supporting respondent); supra Figure 13 (Solicitor General as amicus supporting petitioner); supra Figure 14 (Solicitor General as amicus supporting respondent); supra Figure 15 (ACLU as amicus supporting petitioner); supra Figure 16 (ACLU as amicus supporting respondent); supra Figure 17 (AFL-CIO as amicus supporting petitioner); supra Figure 18 (AFL-CIO as amicus supporting respondent); supra Figure 19 (States as amici supporting petitioner); supra Figure 20 (States as amici supporting respondent).

${ }^{196}$ The Solicitor General filed amicus briefs in only $6.38 \%$ of cases in 1946-1955, but in the most recent decade filed in $28.60 \%$ of cases. See supra note 25 .

197 See supra Figure 7. 
need some other explanation to account for the behavior of these filers.

One possible explanation is that amicus filings have proliferated in accordance with a kind of "arms race" phenomenon. The theory would be that interest groups file amicus briefs out of fear that rival groups will file for the other side. For example, the general counsel of an organization considering whether to file an amicus brief may harbor few illusions that such a brief will have any impact on the outcome of the case. But other officers or the membership of the organization may not be so sophisticated. The great fear of the general counsel may be that the Court will rule adversely to the organization's interest, and in so ruling, may even cite an amicus brief filed in support of the other side. Should this happen, the other officers or members of the organization may demand an explanation for why the group did not file its own brief to protect its interest. One can easily see how, if enough general counsel engage in this kind of worrying, amicus briefs might begin to proliferate, even without any solid evidence that such briefs have much effect on outcomes.

If the arms race conception of amicus participation has any validity, then the number of amicus briefs should tend to be about the same on both sides of a case. ${ }^{198}$ In other words, if groups supporting the petitioner anticipate that groups supporting the respondent will file multiple briefs, then groups supporting the petitioner will file multiple briefs. In contrast, if groups supporting petitioner anticipate that groups supporting respondent will sit out the controversy, or will file only one or two briefs, then there should be few or no briefs filed by the groups supporting petitioner. Over a large enough number of cases (as in our database), one would expect the dispersion of the difference between the number of briefs supporting petitioner and the number of briefs supporting respondent in each case to be narrow, and to spike at zero. In other words, if we subtract the amicus briefs supporting respondent from the briefs supporting petitioner in each case, we should find zero to be the most common number and a high concentration of low numbers on both sides of zero.

193 Arguably, one might think that the number of organizations participating in the filing of amicus briefs should be similar. Examining this would require counting the number of organizations signing on to amicus briefs. But organizations differ greatly in size and financial resources. Numbers of amicus briefs may be a better proxy for intensity of group participation than numbers of organizations, since each amicus brief represents a lump expenditure of roughly the same magnitude as other amicus briefs. Thus, the number of amicus briefs is a crude proxy for the "willingness to pay" of the collective assembly of interest groups on each side of a controversy. Cf. supra note 146. 
To test this prediction, Figure 23 plots the dispersion of the difference in number of briefs supporting petitioner and respondent in cases in which two or more amicus briefs were filed. As can be seen, the dispersion does spike at zero, it is highly symmetrical, and the numbers of cases showing differences greater than three fall off very rapidly. For some reason, the drop-off is not entirely continuous, in that differences of -2 and +2 occur with virtually the same frequency as -1 and +1 .

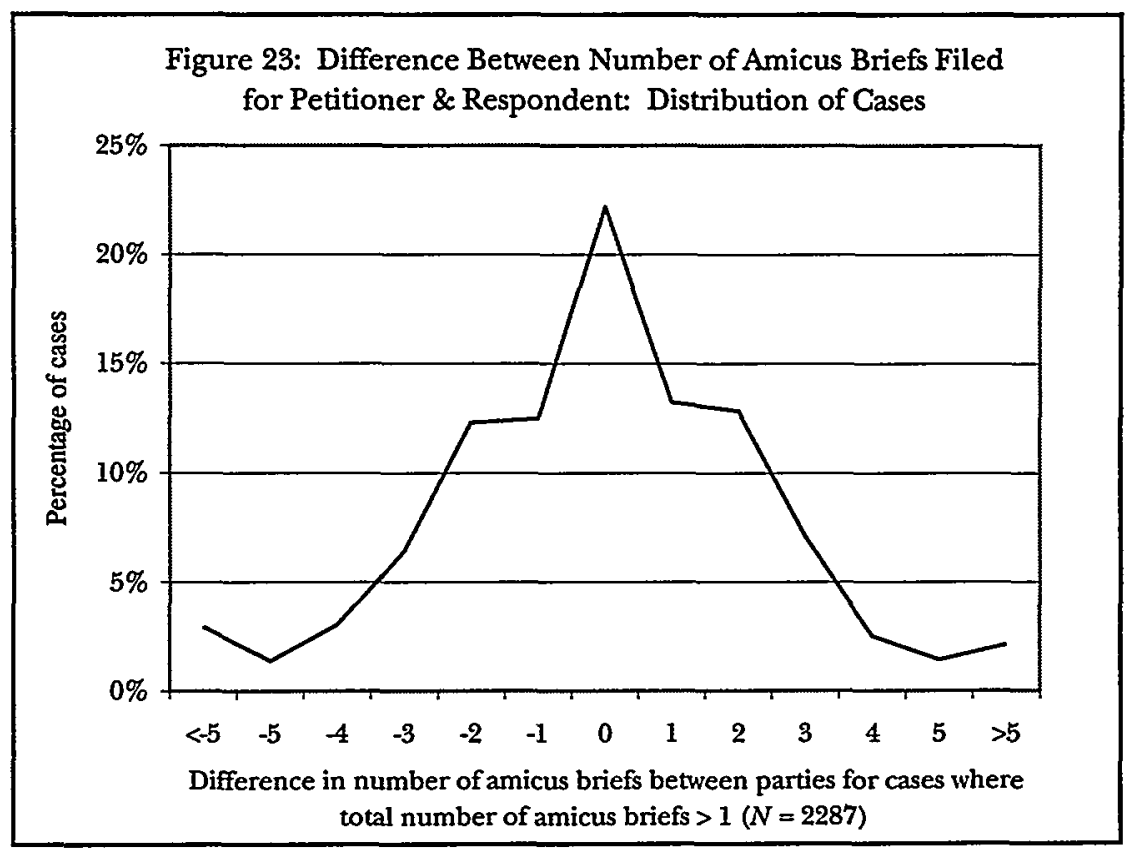

The tendency of amicus briefs to be evenly distributed on both sides not only helps explain the proliferation of amicus briefs, but may also account in part for why a study such as ours has difficulty detecting the substantive impact of amicus briefs. Consider in this regard the interest group theory. Even if the interest group theory of amicus briefs were valid, the arms race phenomenon would make this difficult to detect. This is because one side would rarely succeed in filing large numbers of briefs signalling strong political support to the exclusion of similar filings on the other side. Each side's enlistment of multiple supporting briefs would in most cases cancel out the signalling effects of the other side's efforts. It is theoretically possible, therefore, that 
the interest group model-or simply a widespread acceptance of the validity of the interest group model among organizations interested in Supreme Court litigation ${ }^{199}$-could explain both the rising incidence of amicus participation and the lack of evidence of impact on outcomes, at least as a general matter, from the filing of amicus briefs.

The phenomenon of cases with unusually high numbers of briefs, delineated in Part I, seems consistent with this explanation. For example, in the most extreme case, Webster v. Reproductive Health Services, pro-life forces generated forty-six briefs and pro-choice forces mustered thirty-two. At least on the pro-life side, it appears that there was a deliberate strategy among pro-life groups to try to create the impression, by filing as many briefs as possible, of widespread and intense opposition to Roe $v$. Wade ${ }^{200}$ The pro-choice forces made greater efforts to coordinate their filings so as to avoid repetitive argument. ${ }^{201}$ Still, it is hard to imagine that thirty-two briefs were needed in order to lay out all the considerations relevant to a reaffirmation of Roe $v$. Wade. At some level, the pro-choice forces appear also to have sought to generate the impression of powerful interest group support for the outcome desired. ${ }^{202}$ The net effect was that the two sides largely neutralized each other, at least in terms of trying to demonstrate greater public support for their respective positions.

The relatively even distribution of amicus filings between sides may also explain why we do not see stronger evidence of any effect on outcomes from high-quality briefs, as predicted by the legal model. Insofar as the legal model accurately portrays the judicial process as being concerned with deciding cases correctly-or insofar as organizations interested in Supreme Court cases believe that this is a fair characterization of the judicial process-these organizations will have an incentive to try to commission amicus briefs that provide additional legal arguments and factual data that are of value to the Court in reaching decisions consistent with jurisprudential norms. If both sides share this belief, then we should see some increase in amicus filings-although presumably not as extreme an increase in numbers as the interest group theory would predict.

199 See Morriss, supra note 80 , at 829 (offering evidence that contemporary amicus filers conceive of their role as a form of lobbying directed at the Supreme Court).

${ }^{200}$ See Behuniak-Long, supra note 32, at 268.

201 See id. at 267.

${ }^{202}$ See Epstein, supra note 42, at 658 (quoting sources from both pro-choice and pro-life camps indicating that they sought through widespread amicus filings to show the Court that their respective positions had the support of "mainstream America"). 
Again, however, the net effect of this increase in amicus activity might not be noticeable in terms of overall outcomes. This is because each side's attempt to file amicus briefs with additional arguments and information would to some extent cancel out the other side's effort to come up with new arguments and information. Clearly, there are inherent limits to how many new ideas and background studies can be submitted to the Court. Further, in many cases, by the very nature of things, better arguments and empirical support will favor one side over the other. So the potential for cancelling out the effect of a brief on the other side will not be as dramatic under the legal model as under the interest group model. Still, a combination of the legal model and the arms race hypothesis can also explain how the incidence of amicus participation might rise even though it is not evident from the aggregate data that there are notable benefits from the filing of amicus briefs.

The abortion controversy again illustrates how under the legal model one might see an increase in amicus filings on both sides of an issue. Suppose it is known that pro-choice forces plan to file an amicus brief by a group of legal historians arguing that there was no tradition of regulating abortion at the time of the enactment of the Fourteenth Amendment. ${ }^{203}$ Pro-life forces are likely to regard such a brief as supporting the case for a constitutional right to abortion, and hence would feel compelled to sponsor amicus briefs seeking to show the opposite. The net effect would be that the Court would receive additional and perhaps valuable information to assist its deliberations. It is unlikely, however, that the new information would tip the outcome in one direction or another (although it might have such an impact if only one side submitted such an historical brief).

In addition to the open door policy, the impact on outcomes, and the arms race possibility, it is also important to consider the internal benefits to groups of filing amicus briefs. Political scientists have long been sensitive to the possibility that the real audience for amicus briefs is not the Court but the membership of the group sponsoring the brief..$^{204}$ The Court's increasing proclivity to cite and quote from

${ }^{203}$ See Sylvia A. Law, Conversations Between Historians and the Constitution, 12 PUB. HISTORIAN 11 (1990) (describing her involvement in such an undertaking).

${ }_{204}$ See, e.g., Epstein, supra note 42, at 675-76 (discussing evidence that interest groups file amicus briefs in part for "organizational maintenance" reasons); Puro, supra note 2, at 247 (opining that filing an amicus brief may "be related more to a national group's desire to look good to its members than to a strong desire to affect either the Court or the law"). 
amicus briefs, documented in Part $\mathrm{I}$, is particularly relevant here. Citation or quotation of a brief in the official Reports of the United States Supreme Court can lend legitimacy to a group, and may be used by the group in its publicity efforts to create the impression that it has "access" to or "influence" with the Court. Interest groups can use this impression to obtain new members and contributions. Even if the group's briefs are never cited, the brief can be distributed to members and others as evidence that the group's leadership is diligently pursuing its members' interests in high places. No doubt emulation enters into the picture here as well. If one group starts filing amicus briefs and touting this to its members and others, other groups may be more likely to start filing as well.

Finally, there may be structural explanations for the increase in amicus brief activity. Andrew Koshner, in a recent study, has outlined a number of possible structural causes. ${ }^{205}$ Included in his list are increased activism on the part of the Court, increased legislative activity by Congress, and increased numbers of organized interest groups with permanent offices in Washington, D.C. Specifically, Koshner argues that the Court became more activist in the 1960s and 1970s, which increased the possibility of securing legal change through litigation. ${ }^{206}$ This of course is when the tide of amicus filings started to rise. He also points out that the volume of new legislation from Congress increased substantially about the same time. ${ }^{207}$ New legislation increases the number of unresolved legal questions that have an impact on interest groups, and may stimulate more amicus filings. The growth of interest groups in Washington also parallels the proliferation of amicus briefs, ${ }^{208}$ plausibly suggesting that the permanent institutional presence of these groups in the capital has brought the activity of filing amicus briefs within the reach of many more organizations than was the case before the 1960 s.

We would add two other factors to Koshner's list. The first is the growth in the caseloads in the lower courts. The Supreme Court is extremely constrained in the number of argued cases it can hear and re-

${ }^{205}$ See KOSIINER, supra note 21, at 11-18.

${ }^{206}$ See id. at 55-66 (noting that interest group activism has closely tracked judicial activism).

${ }_{207}^{20}$ See id. at $68-78$ (noting that the total number of pages of legislation passed by Congress correlates well with the number of Supreme Court cases containing amicus briefs).

${ }^{203}$ See id at 84-87; see also Epstein, supra note 42, at 646-49 (providing data about the growth in the number of groups using litigation from 1968 to 1988). 
solve in any given year. ${ }^{209}$ At its peak, the Court heard around 150 cases; today, due to the abolition of mandatory appeals and the Court's own restrictive policies in granting certiorari, ${ }^{210}$ the total is closer to half that. ${ }^{211}$ Meanwhile, the number of cases decided in the lower courts has continued to grow. ${ }^{212}$ Thus, most litigants in the lower courts and most groups interested in issues being litigated in the lower courts will never be able to secure a direct ruling on their issue from the Supreme Court. This situation may create great pressure for litigants and groups to try to influence the way the Court writes opinions in the cases it does decide, in order to secure broad rulings or dicta that may influence the disposition of other matters in the lower courts in a favorable manner. One obvious way to do this would be to file amicus briefs in the most directly relevant cases.

The second factor we would add to Koshner's list is the growth in the number of lawyers. One possible explanation for the surge in amicus filings is that it is lawyer-driven, at least in part, rather than client-driven. ${ }^{213}$ For example, it could be argued that participation in Supreme Court litigation is a highly prestigious activity for law firms, useful in recruiting new associates, retaining talented lawyers in the firm, and securing clients. ${ }^{214}$ Given both the severe constraint on the

209 See Peter L. Strauss, One Hundred Fifty Cases Per Year: Some Implications of the Supreme Court's Limited Resources for Judicial Review of Agency Action, 87 ColUM. L. REv. 1093, 1093-96 (1987).

${ }^{210}$ See Supreme Court Case Selection Act, Pub. L. 100-352, 102 Stat. 662 (1988) (repealing 28 U.S.C. \$ 1252 and thereby eliminating almost all mandatory appeals); Linda Greenhouse, Case of the Shrinking Docket: Justices Spum New Appeals, N.Y. TIMES, Nov. 28, 1989, at A1 (noting Court's restrictive certiorari practices); Linda Greenhouse, Lightening Scales of Justice: High Court Trims Its Docket, N.Y. TIMES, Mar. 7, 1992, at 6 (same).

${ }^{211}$ See supra note 71 (setting forth the number of Supreme Court cases from 1986 to 1995).

${ }^{212}$ See RICHARD A. POSNER, THE FEDERAL COURTS: GHALIENGE AND REFORM 39193 (1996) (providing a table documenting the number of cases before federal courts of appeals and federal district courts since 1892).

${ }^{213}$ Such fragmentary evidence as exists regarding this possibility is conflicting. O'NEIL, supra note 78, at 218, reports that four-fifths of the amicus filers in Bakke stated in response to a survey questionnaire that they were persuaded to file by lawyers. A more general survey of amicus filers at the certiorari stage by Caldeira \& Wright, supra note 81 , at 1112 , suggests that even groups with a large litigation budget and a large number of staff attorneys are cautious in deciding when to file amicus briefs, basing the decision on their interest in, and the merits of, the individual case.

${ }_{214}$ A number of the nation's largest law firms, including Gibson, Dunn \& Crutcher; Hogan \& Hartson; Jones, Day, Reavis \& Pogue; Kirkland \& Ellis; Latham \& Watkins; Mayer, Brown \& Platt; and Sidley \& Austin, have offices in Washington, D.C. that include specialized practices focusing on Supreme Court litigation. 
number of cases argued before the Supreme Court and the increased numbers of lawyers competing for opportunities to appear in such cases, however, the chances of any law firm's having many cases before the Supreme Court are small. Preparing and filing amicus briefs in this context becomes a kind of surrogate activity for real Supreme Court litigation. Law firms may have some control over the volume of this surrogate litigation, insofar as they can either try to persuade their clients that filing amicus briefs is a good idea or offer to file briefs at a reduced rate or even on a pro bono basis.

Figure 24 shows, for purposes of comparison, the rates of change in the number of amicus briefs, the number of cases in the federal courts of appeals, and the number of practicing lawyers in the United States from 1951 (the first date for which common comparative data were readily available) through $1994 .{ }^{215}$ As can be seen, all three lines increase substantially from 1951 to 1994 . Interestingly, however, the rate of change of cases in the courts of appeals tracks the rate of change in amicus briefs more closely than does the rate of change in the number of lawyers. This is a small piece of circumstantial evidence suggesting that the imbalance between the number of lower court cases and the severely constrained number of Supreme Court docket slots has contributed to the rise in amicus briefs. Alternatively, it may mean only that the rise in amicus activity mirrors more general forces in society (whatever exactly they may be) that have produced increased litigation in the federal courts in the last half century.

215 The sources for the data underlying Figure 24 are as follows: the number of cases with amicus briefs comes from our database; the number of cases in the federal courts of appeals is set forth in POSNER, supra note 212, at 391-93 tbl.A.2; and the number of lawyers in the United States is taken from CARL A. AUERBACH, HISTORICAI STATISTICS OF LEGAL EDUCATION 63 tbl.12A (1997). The numbers in Figure 24 itself are expressed in terms of percentage increases, using 1951 data as baselines. 


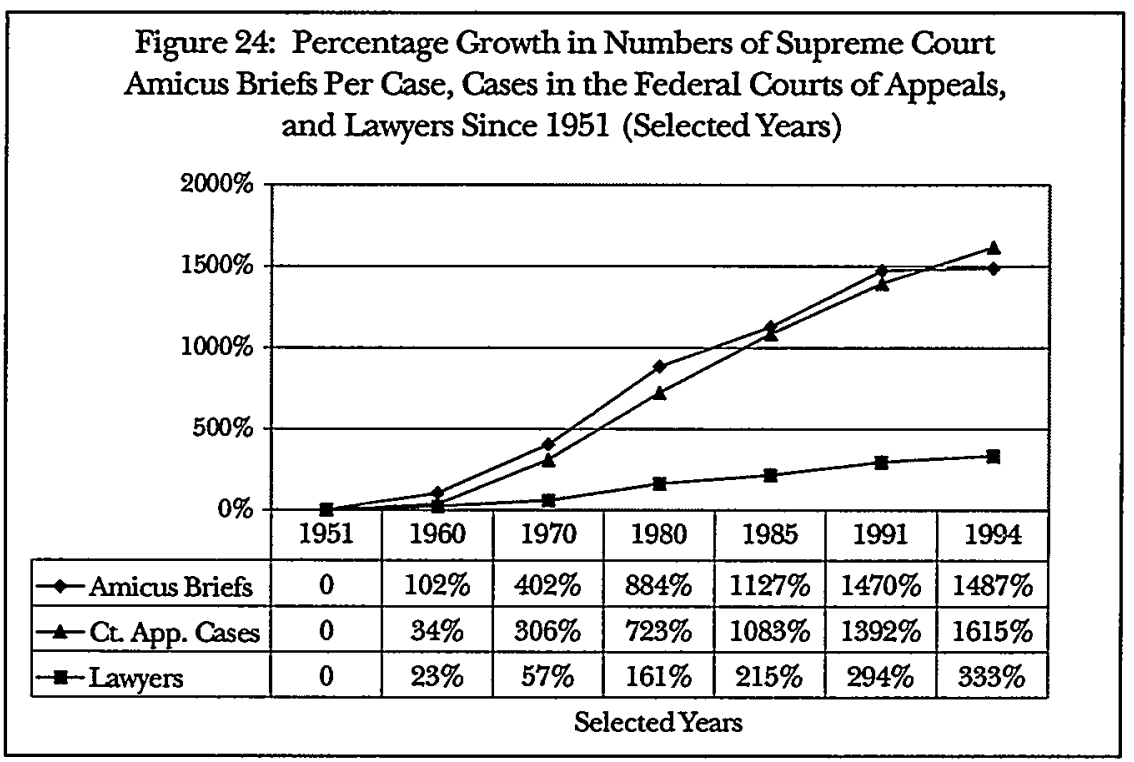

As should be obvious, we are not in any position to offer any definitive judgment about why the amount of amicus curiae activity has risen so much in the Supreme Court during the last fifty years. Further research will be needed in order to learn more about the relative importance of the factors we have identified above, and perhaps other factors as well, in explaining this striking development.

\section{CONCLUSION}

Amicus curiae briefs have become an increasingly important phenomenon in Supreme Court litigation. Once a rarity, such briefs are currently filed in the Supreme Court at the rate of about 500 per year. If nothing else, these briefs consume significant amounts of legal resources-and a significant portion of the shelf space devoted to the Court's records and proceedings. As the number of amicus submissions has soared, so have the citations and quotations of amicus briefs found in the Justices' opinions.

The obvious question is whether, or to what extent, these submissions influence the decisions rendered by the Court. Although political scientists and, to a lesser degree, law professors have turned increasingly to empirical analysis in recent years, no one has undertaken to try to answer this question by analyzing the patterns of amicus participation and associated outcomes in a large number of cases decided 
over a significant span of time. One reason such a study has not been done is that the political scientists who study the Supreme Court overwhelmingly start from the attitudinal model, which explains outcomes in terms of the preexisting political beliefs of the Justices. Such a model suggests that amicus briefs should have little or no impact on outcomes. Perhaps not surprisingly, therefore, the database political scientists use to study the Court (which was developed by attitudinal scholars ${ }^{216}$ ) does not include information on the number of amicus briefs filed in each case in support of each side or by key institutional litigants. The lack of readily accessible data has undoubtedly discouraged empirical research.

In this Article, we report our efforts to fill this gap in our knowledge by developing and analyzing a database consisting of over 6000 Supreme Court decisions over fifty years. Some of our results confirm the findings of previous, more limited studies. Most prominently, our survey shows that the Solicitor General enjoys a unique degree of success as an amicus filer. We also show that other institutional litigants-the ACLU, the AFL-CIO, and the States-enjoy above-average success, although their success rates fluctuate depending on whether they support petitioners or respondents and never reach the same level achieved by the Solicitor General.

In two respects, however, our study generates results wholly unanticipated by the prior literature. First, we show that amicus filers supporting respondents consistently enjoy more success than do amicus filers supporting petitioners. For example, amicus filers who support respondents are in general $7 \%$ more successful than those who support petitioners, and the Solicitor General is $9 \%$ more successful when supporting respondents than when supporting petitioners. ${ }^{217}$

Second, we find that although small disparities of amicus support (one or two briefs to none) may be associated with increased success for the supported party, larger disparities (three briefs or more to none) show little sign of increased success and may possibly even be counterproductive. $^{218}$ Undoubtedly one reason we find little support for higher success rates with larger disparities of filings is that there are very few cases that have such disparities. In most cases the amicus briefs are symmetrically distributed between the parties; patterns like

${ }^{216}$ See supra note 82 (discussing the Supreme Court Database developed by Spaeth).

${ }^{217}$ See supra Figures $7 \& 8,13 \& 14$.

218 See supra Figures 9 \& 10. 
that encountered in Jaffee $v$. Redmond, where fourteen briefs supported respondent and none supported petitioner, are extremely rare.

Regarding the implications our results have in terms of identifying the factors that motivate Supreme Court Justices, we must speak much more tentatively. The attitudinal model, at least in its undiluted form, seems to find the least support in our findings. Amicus briefs clearly do matter in many contexts, and this means that the Court is almost certainly influenced by additional information supplementing that provided by the parties to the case. The strategic actor variation on the attitudinal model fares better, since the Court appears to be more attentive to information supplied by the Solicitor General (representing the executive branch) and, to a lesser degree, to information coming from the States than it is to the information supplied by amicus filers in general. The interest group model, which predicts that the Justices will respond to signals suggesting that organized interest groups disproportionately favor one side over the other, finds only equivocal support. Small disparities of support for one side may matter, although only weakly. Large disparities, however, perhaps because they occur so rarely, cannot be shown to have any impact; indeed, they appear often to work against the interests of the supported party.

We think the explanatory model that fares the best overall is the traditional legal model reflected in the rules and procedures of the Court. Amicus briefs matter insofar as they provide legally relevant information not supplied by the parties to the case-information that assists the Court in reaching the correct decision as defined by the complex norms of our legal culture. This explanation can account for the fact that respondents benefit from amicus support more than petitioners, since it is likely that respondents on the whole are less likely to be represented by experienced counsel. It can also account for the apparent pattern that small disparities of support for one side over the other are associated with greater success on the part of the supported party, since the low-profile nature of these cases may make the Court more attentive to legal arguments. Finally, of course, it is consistent with the remarkable success of the Solicitor General and the significant if less dramatic success of other institutional litigants that employ skilled and experienced Supreme Court advocates. This does not mean that the legal model explains all the Court's decisions. Nevertheless, we think our findings support the conclusion that legal doctrine matters in at least a significant portion of the Court's business. 


\section{APPENDIX A: CASES WTTH TWENTY OR MORE AMICUS BRIEFS, 1946-1995}

The following Table summarizes the issue in the thirty-four cases that have triggered twenty or more amicus briefs during the fifty-year period of our study, indicating also the year and the number of briefs filed.

CASE

SUBJECT MATTER

$\underline{\text { BRIEFS }}$

1 Webster v. Reproductive Health Abortion (constitu78 Servs., 492 U.S. 490 (1989) tional aspects)

2 Regents of the Univ. of Cal. v. Affirmative action

54 Bakke, (constitutionality) 438 U.S. 265 (1978)

3 Cruzan v. Director, Mo. Dep't Right to die (consti39 of Health, 497 U.S. 261 (1990) tutional aspects)

4 Container Corp. of Am.v. Franchise Tax Bd. of Cal., 463 U.S. 159 (1983)

State tax power (constitutionality)

5 Pacific Mut. Life Ins. Co. v. Punitive damages Haslip, (constitutionality) 499 U.S. 1 (1991)

6 Planned Parenthood v. Casey, Abortion (constitu505 U.S. 833 (1992) tional aspects) 
7 United Steelworkers v. Weber, Affirmative action 443 U.S. 193 (1979) (Title VII)

8 Pacific Gas \& Elec. Co. v. Public First Amendment 29 Utils. Comm'n of Cal., 475 U.S. 1 (1986) (speech)

9 Lucas v. South Carolina Coastal Takings (constitu28 Council, tional) 505 U.S. 1003 (1992)

10 Sony Corp. of Am. v. Universal Copyright City Studios, Inc., 464 U.S. 417 (1984)

11 DeFunis v. Odegaard, Affirmative action 26 416 U.S. 312 (1974) (constitutionality)

12 Wisconsin v. Mitchell, First Amendment 26 508 U.S. 476 (1993) (speech)

13 Romer v. Evans, 517 U.S. 620 (1996)

Gay rights (Equal

14 Gity of L.A. v. Preferred Com- First Amendment munications, Inc., 476 U.S. 488 (1986) (speech)

15 TXO Prod. Corp. v. Alliance Punitive damages 509 U.S. 443 (1993) 
16 Federal Energy Regulatory

Comm'n v. Mississippi, 456 U.S. 742 (1982)

17 Babbitt v. Sweet Home Chapter of Communities, 515 U.S. 687 (1995)

18 BMW of N. Am., Inc. v. Gore, 517 U.S. 559 (1996)

19 Dolan v. City of Tigard, 512 U.S. 374 (1994)

20 Wygant v. Jackson Bd. of Educ., 476 U.S. 267 (1986)

21 Yee v. City of Escondido, 503 U.S. 519 (1992)

22 Daubert v. Merrell Dow Pharms., Inc., 509 U.S. 579 (1993)

23 Barclays Bank PLC v. Franchise Tax Bd. of Cal., 512 U.S. 298 (1994)

24 Swann v. CharlotteMecklenburg Bd. of Educ., 402 U.S. 1 (1971)

25 Lemon v. Kurtzman, 403 U.S. 602 (1971)
Federalism/

24 Congressional power

24 dangered Species Act)

Punitive damages

24 (constitutionality)

Takings (constitutional)

23

Affirmative action 22 (constitutionality)

Takings (constitu22 tional)

Expert testimony

22

(Fed. R. Evid.)

State tax power

22 (constitutionality)

School desegrega-

21 tion (Equal Protection Clause)

First Amendment (religion) 
26 City of Akron v. Akron Ctr. for Reprod. Health, Inc., 462 U.S. 416 (1983)

27 Thornburgh v. American College of Obstetricians and Gynecologists, 476 U.S. 747 (1986)

28 Browning-Ferris Indus., Inc. v. Kelco Disposal, Inc., 492 U.S. 257 (1989)

29 Hodgson v. Minnesota, 497 U.S. 417 (1990)

30 Rust v. Sullivan, 500 U.S. 173 (1991)

31 Adarand Constructors, Inc. v. Pena, 515 U.S. 200 (1995)

32 Metro Broad., Inc. v. FCC, 497 U.S. 547 (1990)

33 Lee v. Weisman, 505 U.S. 577 (1992)

34 Board of Educ. v. Grumet, 512 U.S. 687 (1994)
Abortion (constitu-

21 tional aspects)

Abortion (constitu-

21 tional aspects)

Punitive damages

21 (constitutionality)

Abortion (constitutional aspects)

21 First Amendment (speech)

21 Affirmative action 21 (constitutionality) Affirmative action 20 (constitutionality)

First Amendment

20 (religion)

First Amendment 


\section{APPENDIX B: DATA-GATHERING METHODOLOGY}

This Appendix sets forth the basic features of the methodology we used in gathering the data for our study of amicus briefs in the United States Supreme Court. Our essential goal was to record information for every argued case in which the Court took action on a judgment (e.g., affirmed, reversed, vacated) or declined in a dispositive way to do so (i.e., dismissed). The following also summarizes many (though not all) of the types of data that we tracked and some of the more important judgment calls that we made.

\section{The Amicus Brief Study}

Our database consists of virtually every case decided by the Court from October Term 1946 through October Term 1995 in which the Court heard oral argument (more specifically, every such case except as indicated otherwise in this appendix). ${ }^{1}$ We excluded non-argued cases for several reasons. First, the Court ordinarily will not decide an important issue without hearing oral argument and, conversely, will act summarily (i.e., without argument) only where it regards the issues as clearly settled by existing precedent. Second, the Court and the public both tend to regard the argued cases as the Court's business for a particular term. Third, the very low probability that important substantive issues will be decided at the certiorari or probable-jurisdiction stage, combined with a lack of public attention to most cases until the Court accepts them for argument and plenary treatment, means that amicus briefs are relatively rare at this stage of the process. ${ }^{2}$

${ }^{1}$ All of the Court's signed opinions (i.e., those in which a particular Justice is identified as the author who is speaking for the Court), and virtually all of the Court's important decisions, are handed down in argued cases. The remaining opinions are unsigned and are usually denominated as "per curiam" opinions. An argued case will infrequently be decided in a per curiam opinion-for example, if the judgment below is affirmed by an equally divided Supreme Court, or if the Court, after argument, dismisses the writ of certiorari as having been improvidently granted. The determination that a case has been "argued" is straightforward, for the Court indicates the fact and date of the argument at the beginning of each such case.

${ }^{2}$ See Gregory A. Caldeira \& John R. Wright, Organized Interests and Agenda Setting in the U.S. Supreme Court, 82 AM. POL. SCI. REV. 1109, 1116 (1988) (reporting that in 1982 Term amicus briefs were filed in only 7.78\% of the Court's cases (148 out of 1906) at the certiorari petition stage). 
Several observations concerning the inclusion or exclusion of particular types of argued cases are appropriate. Notwithstanding their detailed nature, these observations concern only a small percentage of the cases in our database. First, we excluded some small categories of the Court's decisions in argued cases. In particular, we generally eliminated any reported decisions, even if listed as argued, that did not take action on a judgment from another court (e.g., by affirming, reversing, or vacating) or decline in a dispositive way to do so (i.e., by dismissing). These included reports of decisions that merely continued cases on the docket pending some further action, ${ }^{3}$ acted on motions, ${ }^{4}$ or otherwise did not act on some judgment. ${ }^{5}$ These also in-

${ }^{3}$ To take one example, the Court occasionally followed a practice of certifying the question to a state court if it was unclear whether a decision of the state court rested on an adequate and independent state ground that would bar federal review. The Supreme Court would report its certification and continue the case on its docket pending receipt of the answer from the state court, whereafter the Court would take up the case or decline to do so (depending upon the answer). In this circumstance, although the case would be reported twice (or more) in the United States Reports (each continuance and then the ultimate disposition), it seemed improper to treat this as more than one case. We therefore ordinarily included only the ultimate decision in our database. For an example of this, compare Hammerstein v. Superior Court of California, 340 U.S. 622 (1951), which continued the case so that counsel could obtain rulings from state courts on state or federal basis for decision below (and therefore was not included by us), with Hammerstein v. Superior Court of Califormia, 341 U.S. 491 (1951), which dismissed the case based on resulting rulings (and therefore was included by us).

${ }^{4}$ See, e.g., Rosenberg v. United States, 346 U.S. 273 (1953) (denying motion to vacate stay and therefore not included); United States v. National City Lines, Inc., 337 U.S. 78 (1949) (denying petition for certiorari in argued case); Ex parte Collett, 337 U.S. 55 (1949) (denying motion for leave to file petitions for writs of mandamus and prohibition); Hirota v. MacArthur, 338 U.S. 197 (1948) (denying motions for leave to file petitions for writs of habeas corpus). But cf. Mesarosh v. United States, 352 U.S. 1 (1956) (denying motion to remand but also reversing judgment below and therefore included).

${ }^{5}$ Compare, e.g., Rowoldt v. Perfetto, 354 U.S. 934 (1957) (restoring case to calendar for reargument and therefore not included), with Rowoldt v. Perfetto, 355 U.S. 115 (1957) (deciding case and therefore included by us); Alton v. Alton, 347 U.S. 965 (1954) (merely entering order to show cause and therefore not included), with Alton v. Alton, 347 U.S. 610 (1954) (vacating judgment below and therefore included).

In cases such as these that were reported more than once, see also supra note 3, we counted what we determined was the total number of amicus briefs filed by different entities. The number of amicus briefs filed in such a case may have been indicated in any of several different ways, including the following: (a) in the first report, compare, e.g., Elkins v. Moreno, 435 U.S. 647 (1978) (certifying question and listing one amicus brief), with Toll v. Moreno, 441 U.S. 458 (1979) (deciding same case after certified question was answered and listing no amicus briefs); or (b) more frequently, in the second report, compare, e.g., Baker v. Carr, 366 U.S. 907 (1961) (setting case for reargument and listing five amicus briefs), with Baker v. Carr, 369 U.S. 186 (1962) (deciding case and listing seven amicus briefs, five of which were filed by the same entities as stated in the report on the original argument, wherefore we counted seven amicus 
cluded cases within the Court's original jurisdiction. ${ }^{6}$ On the same principle, we excluded three cases where the Court answered a certified question, ${ }^{7}$ but included one certified case where the Court exercised its option to order the entire case sent up. ${ }^{8}$

Second, in contrast to the foregoing, but under similar principles, where a case was reported twice because the Court granted rehearing, we included both decisions if the Court had the case reargued and issued substantive decisions in each instance (e.g., if notable determinations of law were made or action was taken on the judgment). ${ }^{9}$ We

briefs); Scales v. United States, 360 U.S. 924 (1959) (setting case for reargument and listing no amicus briefs), with Scales v. United States, 367 U.S. 203 (1961) (deciding case and listing one amicus brief); or (c) identically in both reports, compare, e.g., International Ass'n of Machinists v. Street, 363 U.S. 825 (1960), with International Ass'n of Machinists v. Street, 367 U.S. 740 (1961) (each listing the same two amicus briefs); Ellis v. Dixon, 348 U.S. 881 (1954), with Ellis v. Dixon, 349 U.S. 458 (1955) (each listing the same amicus brief). Where the reports of such cases contained a discrepancy with regard to the side on which an amicus brief had been filed, we used our best judgment. For example, in Perez v. Brownell, 354 U.S. 934 (1957) (restoring case to calendar for oral argument), and Perez v. Brownell, 356 U.S. 44 (1958) (deciding case), the first report lists John W. Willis as having filed an amicus brief for Mendoza-Martinez in support of petitioner; second lists Willis simply as having filed an amicus brief for the same individual but does not specify whether the brief supported petitioner or respondent. From the context of the case, it was not difficult to conclude that the amicus brief supported petitioner, and we so recorded it in our database. Finally, under the principle set forth at the beginning of this paragraph, we did not double-count when the same entity filed two amicus briefs. Compare, e.g., Griffin v. Maryland, 373 U.S. 920 (1963) (restoring case to docket for reargument and listing one amicus brief filed by the United States), with Griffin v. Maryland, 378 U.S. 130 (1964) (deciding case and listing another amicus brief filed by the United States).

${ }^{6}$ See U.S. CONST. art. III, § 2; 28 U.S.C. \$ 1251 (1994). There were more than 100 original-jurisdiction cases from 1946 to 1995 . These cases tend to be disputes between states or between a state and the United States. See generally RICHARD H. FALION ET AL., HART AND WECHSLER's THE FEDERAL COURTS AND THE FEDERAL SYSTEM 294-347 (4th ed. 1996) (discussing original jurisdiction). We excluded them because they are of a fundamentally different nature from the Court's appellate-jurisdiction cases. In original-jurisdiction cases, the Court does not "affirm," "reverse," or "vacate" another Court's judgment but acts instead as a Court of first instance and indeed as a factfinder. Results in original-jurisdiction cases therefore tend to be such actions as "motion for leave to file bill of complaint granted" or "exceptions to special master's recommendations overruled" and therefore cannot be correlated to appellate-jurisdiction results.

${ }^{7}$ See United States v. Barnett, 376 U.S. 681 (I964); Woods v. Hills, 334 U.S. 210 (1948); Shade v. Downing, 333 U.S. 586 (1948).

${ }^{8}$ See 28 U.S.C. $\$ 1254(2)$ (1994) (giving Court the option); Alison v. United States, 344 U.S. 167 (1952).

${ }^{9}$ See, e.g., Graver Tank \& Mfg. Co. v. Linde Air Prods. Co., 336 U.S. 271 (1949) (reversing in part judgment of the court of appeals in a patent case), with Graver Tank \& Mfg. Co. v. Linde Air Prods. Co., 339 U.S. 605 (1950) (on rehearing, discussing substantive aspects of patent law and adhering to prior decision); Marzani v. United States, 335 U.S. 895 (1948) (affirming, per curiam, the lower court), with Marzani v. United 
applied the same principle where a case was reported twice either because it was reargued, even though not technically reheard, ${ }^{10}$ or because the Court certified a question to another court. ${ }^{11}$

Two major problems were presented in tabulating the data-one regarding the classification of inputs (the amicus briefs), the other the classification of outputs (the decisions of the Court). As described further below, our objective in both respects was to reduce the inputs and outputs to a dichotomous form as much as possible.

With respect to the classification of the amicus briefs, this process involved classifying briefs as being either "for petitioner" or "for respondent." For each argued case in our fifty-year period we divided the amicus briefs into the same categories used by the Reporter of Decisions in the United States Reports. ${ }^{13}$ There are several reasons why we

States, 336 U.S. 922 (1949) (reaffirming the earlier per curiam decision).

${ }^{10}$ Compare, e.g., Bolling v. Sharpe, 347 U.S. 497 (1954) (deciding main constitutional question in case), and Brown v. Board of Educ., 347 U.S. 483 (1954) (same), with Brown v. Board of Educ., 349 U.S. 294 (1955) (reporting decision after Brown and Bolling had been reargued on the question of relief); Rusk v. Cort, 369 U.S. 367 (1962), with Kennedy v. Mendoza-Martinez, 372 U.S. 144 (1963) (same case as Rusk). Again, however, we did not include both reported decisions if one of them was not substantive. Compare, e.g., Griffin v. Illinois, 349 U.S. 949 (1955) (merely appointing counsel in case), with Griffin v. Illinois, 351 U.S. 12 (1956) (deciding case).

"Compare Zant v. Stephens, 456 U.S. 410 (1982) (certifying question but also deciding substantive issues), with Zant v. Stephens, 462 U.S. 862 (1983) (deciding case and thus also deciding substantive issues).

${ }_{12}$ These are the terms for the parties in Supreme Court practice in cases in which the Court's jurisdiction is based on a writ of certiorari. The party seeking to overturn the judgment below is the petitioner, and the party defending the judgment below is the respondent. We use the same terminology throughout, even though in some cases the Court's jurisdiction is based not on a writ of certiorari, but on a right of appeal (which is now rare but was in the earlier years of the study more common, see Supreme Court Case Selection Act, Pub. L. 100-352, 102 Stat. 662 (1988) (repealing 28 U.S.C. $\S 1252$ and thereby eliminating almost all mandatory appeals)). The technical terms used in such cases are "appellant" and "appellee." Our database contains 4861 cases on certiorari ( $79.16 \%$ of all argued cases in our database), 1279 cases on appeal $(20.83 \%)$, and one case on certificate $(0.02 \%)$.

${ }^{13}$ In some instances, we had to grapple with the difficult issue of how to count amicus briefs in cases where the Court consolidated together two or more cases and a different number of amicus briefs were filed in the different cases. Consider the example of Plyler v. Doe, 457 U.S. 202 (1982). In Plyler, the lead case, three amicus briefs were filed in support of petitioner, ten in support of respondent, and four "other" briefs (see infra text accompanying notes 15-21 for a description of this last category). However, Plyler was decided by the Court " $[\mathrm{t}]$ ogether with No. 80-1934, Texas et al. v. Certain Named and Unnamed Undocumented Alien Children et al." Plyler, 457 U.S. at 202 n.*. This second case had two amicus briefs supporting petitioner, nine supporting respondent, and five "other" briefs; some of these were the same as the briefs in Plyler, others were not. This phenomenon of multiple cases, with different numbers of amicus briefs, brought together for decision was not a rarity (the number of such cases well exceeded 100). 
chose to adopt the Reporter's classification of amicus briefs. First, this information is readily accessible in any set of the United States Reports, and so it is relatively easy (though still time-consuming) to gather information about a very large number of cases. Second, the Reporter's office has a deserved reputation for meticulousness, and so we are highly confident that the office faithfully follows its chosen method of classification. ${ }^{14}$ Third, the Reporter's office classifies amicus briefs based on unambiguous statements made by the amici themselves; thus, we can be confident that the briefs listed by the Reporter as being "for petitioner" or "for respondent" do in fact support the parties they are said to support.

The major drawback to adopting the Reporter's method of classification is that it quite clearly undercounts the true number of amicus briefs supporting either one side or the other. At the end of the official syllabus for each case prepared by the Reporter's office, the Reporter's staff adds a footnote that lists all the amicus briefs filed in the case, arranged in three categories. ${ }^{15}$ The first category consists of

We decided not to look upon such consolidated cases as separate cases, for they were not so regarded by the Court or by the public, and such an approach would therefore result in an overcount on the output side. Lacking an entirely satisfactory approach, we decided to count only amicus briefs in the lead case in such instances, with one exception: if the lead case was the subject of no amicus briefs, and a case consolidated "together with" that case did have amicus briefs, we used the "together with" case that contained the largest number of briefs. We viewed this imperfect approach as better than the alternatives, such as recording the "average" number of amicus briefs for each side in the consolidated cases or strictly looking to the lead case (for in the latter instance a decision could be recorded as having no amicus briefs even if many were filed in a "together with" case).

${ }^{13}$ Our random sample of 99 cases, see infra text following note 18 , confirms that the Reporter's office quite faithfully applies its methodology in classifying amicus briefs. But cf. infra note 17 (setting forth a few instances in which the Reporter has appeared to include in the "other" category briefs that under the classification scheme summarized here should have been in either petitioner's category or respondent's category). We are also confident that the Reporter's office is highly reliable on the even more basic question whether an amicus brief was filed in a case and, if so, by whom. It is true that we discovered a few isolated cases where the Court but not the Reporter refers to an amicus brief. See FCC v. ITT World Communications, Inc., 466 U.S. 463, 473 n.12 (1984); Mississippi Univ. for Women v. Hogan, 458 U.S. 718, 735 (1982) (Powell, J., dissenting). Individual examination of these briefs reveals, however, that in these instances the Court has cited amicus briefs filed in support of the petition for certiorari.

${ }^{15}$ Until Volume 410 of the United Stales Reports (which was in the midst of October Term 1972 and, perhaps more relevantly, contains the Court's decision in Roe v. Wade, 410 U.S. 113 (1973)), this information was set forth in the text of the syllabus, along with the information concerning counsel for the parties. Presumably, the increasing number of amicus briefs (and hence the increasing space required to list the lead amicus and all counsel on the brief who are members of the Supreme Court Bar) prompted the move of the amicus information to a footnote (except in instances 
briefs identified by the Reporter of Decisions as amicus briefs "urging reversal" of the judgment under review, i.e., supporting the petitioner in cases before the Court on a writ of certiorari (an overwhelming majority of the cases) or the appellant in cases on appeal. The second category consists of briefs denominated by the Reporter as "urging affirmance," i.e., supporting the respondent or the appellee. The third category consists of what we termed "other" amicus briefs-i.e., briefs that the Reporter of Decisions does not specify as supporting a particular party or urging a particular result.

This third category contained approximately one-fifth of all amicus briefs. Based on our experience, this struck us as a substantially larger percentage of amicus briefs than those in which in fact no result is urged upon the Court. ${ }^{16}$ We learned from the current Reporter of Decisions that this third category includes all briefs not containing an indication of the desired result in the "conclusion" section at the end of the brief. ${ }^{17}$ This means that a brief that clearly urges a particular result throughout will not be categorized as having done so unless the desired result is also made explicit, in accordance with convention, at the end of the brief. $^{18}$

In order to determine whether the briefs in this third category (i.e., that of "other" briefs) deviated materially from the briefs urging reversal or affirmance, in terms of the side that they were actually supporting, we conducted a random survey of these "other" briefs. Our overall study contained 1082 cases between 1946 and 1995 with

where an amicus orally argues, in which case the information concerning that amicus remains in the text along with the information concerning the parties).

${ }^{16}$ Using the Reporter's method, $17.49 \%$ of all the amicus briefs in our study fell into the "other" column, whereas in the earlier study by Puro (who evidently examined the briefs individually), only $3 \%$ of such briefs did not support either the petitioner or the respondent. See Steven Puro, The Role of Amicus Curiae in the United States Supreme Court: 1920-1966, at 110 (1971) (unpublished Ph.D. dissertation, State University of New York at Buffalo) (on file with the University of Pennsylvania Law Review).

${ }_{17}$ Telephone Interview with Frank D. Wagner, Reporter of Decisions, United States Supreme Court (Oct. 29, 1997). It should be noted that we found a scattered handful of cases in which the Reporter's office appears to have departed from its methodology by lumping all or almost all of a case's amicus briefs in the "other" category even when the desired results were set forth in some of the briefs' conclusion sections. See, e.g., Planned Parenthood v. Casey, 505 U.S. 833 (1992); Roe v. Wade, 410 U.S. 113 (1973); Swann v. Charlotte-Mecklenburg Bd. of Educ., 402 U.S. 1 (1971).

${ }^{18}$ For example, in Cardinal Chemical Co. v. Morton Intermational, Inc., 508 U.S. 83 (1993), the Reporter of Decisions lists Atochem North America, Inc. as one of the entities that filed an amicus brief but does not set forth the result the company urged. See $i d$. at 85 n.*. Nonetheless, the Court had no difficulty understanding the company's desires. See id. at 87 n.6 ("Atochem has also filed a brief amicus curiae in this Court, urging our reversal of the Federal Circuit practice."). 
one or more "other" amicus briefs; the total number of such briefs was 2236. From these 1082 cases, we individually examined the amicus briefs in ninety-nine randomly selected cases. This subset contained 256 "other" amicus briefs. After reviewing these 256 briefs, we placed them into three sub-categories: (a) those actually urging reversal, (b) those actually urging affirmance, and (c) true "other" briefs, i.e., those in which the amicus was actually supporting neither party but either was advocating a "split-the-difference" rationale or had some other concern it wanted to bring to the Court's attention. Although the process itself was laborious, it was generally not difficult to determine into which category a brief should be placed. For example, many of these briefs actually specified on their cover the party that they were supporting, but were placed in the "other" category by the Reporter of Decisions merely because of the absence of the appropriate language in the concluding section of the brief as described above. $^{19}$

The results of this random survey support the conclusion that the ratio of support for petitioners and respondents among the amicus briefs within the "other" category is approximately equal to the ratio of support for petitioners and respondents among amicus briefs identified by the Reporter as supporting petitioners and respondents. Of the 256 "other" amicus briefs we examined, 240 in fact supported either the petitioner or the respondent. ${ }^{20}$ Of these 240,127 (or 52.92\%) supported the petitioner, and 113 (or $47.08 \%$ ) supported the respondent. Of all amicus briefs in our database, 5117 (or $50.32 \%$ of all amicus briefs listed as supporting petitioner or respondent) are listed by the Reporter of Decisions as supporting the petitioner, and 5052 (or $49.68 \%$ ) as supporting the respondent. In other words, support was almost exactly evenly divided between petitioners and respondents. Given that the breakdown of "other" briefs in the random study actually supporting the petitioner or the respondent is also close to even, we are reasonably confident that we can ignore the briefs in the "other" column for most purposes without distorting our general

${ }^{19}$ To use an actual example, if an amicus states on the cover of its brief that the brief is filed in "support of petitioner," and if the conclusion paragraph makes clear the rule of law sought by the amicus but fails to state that the decision below should be reversed, the brief will be put in the "other" column, even though it clearly supports the petitioner. Compare, e.g., Montanye v. Haymes, 427 U.S. 236, 236-37 n.* (1976) with Brief for Amicus Curiae State of California, Montanye v. Haymes, 427 U.S. 236 (1976) (No. 74-520).

${ }^{20}$ In other words, only 16 of the briefs were true "other" briefs (i.e., subcategory (c) briefs). 
overall findings.

With respect to the classification of outputs, we adopted the following procedure. Seeking to dichotomize our classification as much as possible, we settled upon the basic output categories of "petitioner wins" ("p-win") and "petitioner loses" ("p-loss"), with cases containing a mixed result from the petitioner's perspective (e.g., a partial affirmance and partial reversal of a lower court judgment) falling into a "mixed result" category. We then placed each case into one of these categories according to the Court's disposition or judgment in the case. ${ }^{21}$

This categorization of the individual decisions was fairly straightforward. A case was categorized as a p-loss if it reflected a failure by the petitioner to obtain relief from the lower court's judgment. Accordingly, cases where the lower court judgment was reported as "affirmed" (comprising $31.90 \%$ of all argued cases) constituted the vast bulk of $p$-losses. Other $p$-losses consisted of judgments reported as "affirmed in part,", "affirmed by an equally divided Court," "23 "dismissed," and "dismissed as improvidently granted." Conversely, we classified cases where the lower court's judgment was reported as "reversed" or "vacated" as p-wins, for each represents a setting aside of the lower

${ }^{21}$ We relied upon the report of the Court's judgment as set forth in the syllabus of the Reporter of Decisions preceding each case. This report is most often a verbatim recitation or restatement of the Court's judgment as set forth as the last line of the majority, plurality, or other principal decision. In some instances, the Reporter's statement of the judgment is a more succinct summary than that provided by the Court itself.

${ }_{22}$ This category, which contained only 11 cases (or $0.18 \%$ of cases in our database), consists of cases where the judgment below was only reported as being affirmed in part, see, e.g., Gladstone v. Village of Bellwood, 441 U.S. 91, 92 (1979), and thus does not include cases where that result was combined with another result, which was unfavorable to the petitioner, see, e.g., Jeffers v. United States, 432 U.S. 137, 138 (1977) (reporting judgment below as "affirmed in part, vacated in part"); Abney v. United States, 431 U.S. 651, 652 (1977) (reporting judgment below as "affirmed in part, reversed in part").

${ }^{25}$ This result, which occurred in 98 cases (or $1.60 \%$ of cases in our database), obtains where, for reasons such as illness or recusal, the Court hears a case with less than the usual nine-member complement and then divides evenly as to the proper disposition of the case. See, e.g., Cory v. Western Oil \& Gas Ass'n, 471 U.S. 81 (1985); Gara v. United States, 340 U.S. 857 (1950). Its effect is the same as an affirmance by a majority vote of the Court, although the judgment is usually reflected merely in an order and is not accompanied by an opinion or other statement of reasons. Such a judgment is also not entitled to any precedential weight. See Neil v. Biggers, 409 U.S. 188, 192 (1972).

${ }^{24}$ These reported results ("dismissed" and "dismissed as improvidently granted," the latter being known as "dig" in the vernacular) collectively comprised 182 cases (or $2.96 \%$ of cases in our database). 
court's judgment. ${ }^{25}$ Reversals constituted $50.11 \%$, and vacaturs $8.26 \%$, of the cases in our database. Other p-wins included judgments reported as "reversed in part," "vacated in part," "reversed in part, vacated in part," and "set aside." ${ }^{27}$ Finally, the mixed result category consisted of cases where judgments were reported as "affirmed in part, reversed in part," "affirmed in part, vacated in part," "modified," "remanded," or under similar denominations, or where some miscellaneous action was taken.

${ }^{25}$ The classification of cases where the judgment below was vacated as p-wins is not entirely satisfactory. There are a substantial number of cases in which the Court vacates a judgment even though it substantially agrees with the action of the court below and the argument of the respondent. The result in these cases is a vacatur instead of an affirmance for some other reason, such as a clarification by the Court of the applicable legal standard accompanied by a remand to the lower court for application of the standard, even if the same result seems likely, see, e.g., Wilson v. Seiter, 501 U.S. 294, 306 (1991) ("Out of an abundance of caution, we vacate the judgment of the Sixth Circuit and remand the case for reconsideration under the appropriate standard [which we have just announced]."), or a concern by the Court that a state court might have reached a different result but for a misapprehension of federal law, see, e.g., United Air Lines, Inc. v. Mahin, 410 U.S. 623, 624, 632 (1973) (deciding that federal law does not control an issue and so "vacat[ing] the judgment and remand[ing] the case for consideration of an issue under state law" in order "to avoid the risk of 'an affirmance of a decision which might have been decided differently if the court below had felt free, under our decisions, to do so"m (quoting Perkins v. Banguet Consolidated Mining Co., 342 U.S. 437, 443 (1952))).

While an argument exists for classifying this subset of vacaturs as p-losses or mixed results, we decided not to do so for a number of reasons. First, such "reclassification" would have required individually assessing each case vacating the judgment below-a process that not only would have been substantially more time-consuming than even our classification procedure, but also would have required close judgments in some cases as to whether or not the case was "really" a p-win or "really" a p-loss. The fact that our other classifications were mechanical (and thus that our data are reproducible and confirmable by others) also made us disinclined to engage in such discretionary reclassification. Second, our review of the data persuaded us that the cases at issue were a minority of the vacaturs in our database (for an example of a case demonstrating the ordinary equivalence of a vacatur and a reversal, see Killian $v$. United States, 368 U.S. 231, 239-44 (1961) (remanding after vacatur for new fact-finding and entry of a new judgment)) and reminded us that, even if for only technical reasons, the result of the Supreme Court's decision was that the judgment of the lower court was set aside, contrary to the ungings of the respondent.

${ }^{26}$ Where they were classified as p-wins, these cases had judgments that consisted only of partial reversals or mly of partial vacaturs. Cf. supra note 22 and accompanying text. These cases respectively made up $0.54 \%$ and $0.10 \%$ of our database.

${ }^{27}$ This last classification of "set aside" is the Reporter's characterization of the judgment in only four cases from our database (or 0.07\%), see, e.g., Woodby v. INS, 385 U.S. 276, 277 (1966); United States v. Fruehauf, 365 U.S. 146, 146 (1961); NLRB v. Local Union No. 1229, 346 U.S. 464, 464 (1953), and such a judgment appears to be no different in effect from a vacatur. 


\section{The Citation Study}

We gathered our data on citations and quotations by initially running a LEXIS search for Supreme Court cases within our time period that referred to "amicus," "amici," or "friend(s) of the court" and then examining each case turned up by our search. We chose this approach because any alternative would have been impractical in the extreme. Specifically, we would have had to read closely each case from the past fifty years (or at least each case that was not turned up by our search results) to ensure that the Court did not employ other rhetorical approaches possibly referring to an argument made by an amicus, such as "It has been argued that ...." We concluded that the thousands of additional hours that would have been required for this approach could not be justified by the marginal additional value yielded in the form of a perhaps somewhat more precise count of the number of references by the Court to amicus arguments. Our conclusion was strengthened by our observation that the Court is generally consistent in identifying any amicus to which it refers as, in fact, being an amicus.

There is an inherent difficulty in defining exactly what is meant by a "citation" of an amicus brief in a Supreme Court opinion. The Court frequently does not specifically cite the brief or briefs of amici when it makes reference to some argument or information supplied by the amici. ${ }^{28}$ Thus, we did not confine our count to instances of formal citation of briefs. Instead, we included as a "citation" any reference by the Court to the argument or information provided by a particular amicus, and did not distinguish between references to briefs (or oral argument) of an amicus, on the one hand, and less targeted references to an amicus, on the other.

Our approach in this respect arguably results in an overcount of references to arguments of amici. Sometimes the Court will refer to the amici in a case only in the most passing of ways, as, for example, by saying "petitioner and its amici argue ...." ${ }^{29}$ This would not itself be a problem if the Court were equally likely to use such a formulation throughout the period of our study. Our review of the data that we

${ }^{28}$ See, e.g., Dewsnup v. Timm, 502 U.S. 410, 415 (1992) (referring to argument of an amicus but not citing its brief); In re Permian Basin Area Rate Cases, 390 U.S. 747, 804 n.82 (1968) (same).

${ }^{29}$ See, e.g., Landgraf v. USI Film Prods., 511 U.S. 244, 282 n.35, 285 (1994) (refer-

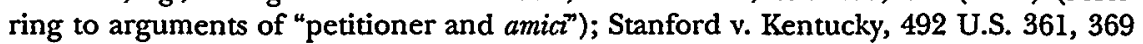
n.1, 374, 377 (1989) (same for "petitioners and their amici" "petitioners and their various amici" and "petitioners and their supporting amici"); Mallard v. United States Dist. Ct., 490 U.S. 296, 310 (1989) (same for "respondents and their amici"). 
collected made it clear, however, that these formulations, while not unknown in the early years of the half-century that we examine, have become increasingly popular as time has gone on. For example, while we discovered no case in the first five years of our study that used the formulation "petitioner and its amicus" or any variant thereof, there were routinely several such cases a year by the 1980 s.

On the other hand, our approach also results in some undercounting. For example, our approach would not disclose any cases in which the Court referred to an argument of an amicus but failed to identify it as such. Our approach is especially likely to have undercounted references by the Court to arguments made as amicus by the Solicitor General, if the frequency of the Solicitor General's amicus filings makes the Court feel less of a need to identify a particular argument by the Solicitor General as having been made in an amicus brief. $^{30}$ Our approach would also not disclose any case in which the amicus making an argument was not even identified-for example, if the Court merely stated "It has also been suggested that ...."

Given our goal of focusing on the effect on the Court of amicus arguments in a particular case, we excluded (i.e., did not count) references to an amicus or amici that did not appear as such in the case before the Court. This means, more specifically, that we excluded (a) the Court's references to the general phenomenon of amici curiae, ${ }^{31}$ (b) its references to an amicus in another Supreme Court case, ${ }^{32}$ (c) its references to an amicus who participated in the course of lower court proceedings, ${ }^{33}$ and (d) its references to the absence of amici. ${ }^{34}$

${ }^{s 0}$ See, e.g., Head v. New Mexico Bd. of Exam'rs in Optometry, 374 U.S. 424, 431 (1963) (referring to argument of United States but not identifying United States as amicus).

${ }^{\text {s1 }}$ See, e.g., Insurance Group Comm. v. Denver \& Rio Grande W. R.R., 329 U.S. 607, 621 (1947) (Frankfurter, J., dissenting) ("The Government frequently intervenes as amicus curiae in so-called private litigation to present the dominant public aspects of such litigation.").

${ }_{32}$ See, e.g., Arkansas v. Oklahoma, 503 U.S. 91, 100 n.6 (1992) (referring to an amicus brief filed by the United States Solicitor General in a 1987 case); Planned Parenthood Ass'n, Inc. v. Ashcroft, 462 U.S. 476, 487 n.10 (1983) (referring to an amicus brief filed by the American Public Health Association in several other cases in the same Term).

${ }^{33}$ See, e.g., Florida v. Wells, 495 U.S. 1, 5-6 (1990) (Brennan, J., concurring) (referring to an amicus that participated in the state supreme court decision under review); Universal Oil Prods. Co. v. Root Ref. Co., 328 U.S. 575, 579-81 (1946) (discussing whether amici in a lower federal court who argued in favor of setting aside a fraudulent judgment were entitled to attorneys' fees and costs).

${ }^{3}$ See, e.g., Yellow Freight Sys., Inc. v. Donnelly, 494 U.S. 820, 822 n.2 (1990) (not- 
The only close question among these was whether to count references by the Court to amicus briefs filed in another Supreme Court case. In some instances, such amicus briefs were filed in sufficient proximity to the case in which they were actually cited that excluding them from the database seemed unduly arbitrary. ${ }^{35}$ In most instances, however, the briefs thus excluded were not so contemporaneous. ${ }^{36}$ In all events, we determined to exclude such briefs from our database for a variety of reasons: such briefs were not designed to influence the Court in the case in which they were cited; they were not presented to the Court in that case; and such a non-discretionary approach to classification is consistent with the nature of our study. By contrast, we included the handful of references by the Court to amici who participated at the certiorari stage, reasoning that all such briefs both were designed to have an influence in that particular case and apparently did. $^{37}$

ing the absence of an amicus brief of the United States).

${ }^{35}$ For example, in Roaden $v$. Kentucky, the amicus brief to which the court refers was filed in a case decided the same day as Roaden. See 413 U.S. 496, 505 n.6 (1973) (citing amicus brief filed in Heller v. New York, 413 U.S. 483 (1973)); see also Planned Parenthood Ass'n, Inc. v. Ashcroft, 462 U.S. 476, 487 n.10 (1983) (referring to an amicus brief filed in three other cases that Term).

${ }^{36}$ In Cantor v. Detroit Edison Co., for example, the amicus brief to which various Justices refer had been filed more than four decades previously in Parker v. Broum, 317 U.S. 341 (1943). See 428 U.S. 579, 587-90 (1976) (discussing amicus brief filed by the Solicitor General in Parker); id. at 618-22 (Stewart, J., dissenting) (disagreeing with the plurality's interpretation of the amicus brief filed in Parker).

${ }^{37}$ See, e.g., Capital Cities Cable, Inc. v. Crisp, 467 U.S. 691, 697 (1984) (emphasizing that an amicus brief filed by the FCC while the petition for certiorari was pending raised additional questions about the legality of the Oklahoma statute at issue); National R.R. Passenger Corp. v. National Ass'n of R.R. Passengers, 414 U.S. 453, 467 (1974) (Douglas, J., dissenting) (referring to a position taken by the Solicitor General in an amicus brief in support of the petition for certiorari); Callen v. Pennsylvania R.R., 332 U.S. 625, 630 \& n.* (1948) (quoting an amicus brief in support of the petition for certiorari). This approach also took support from the fact that in some instances the Court cited amicus briefs filed at the petition for certiorari stage without indicating that it was not referring to briefs filed at the merits stage. Seesupra note 14. 


\section{APPENDIX C: STATISTICAL ANALYSIS}

We have not included standard tests of statistical significance in connection with the data reported in the twenty-four figures throughout the paper. Standard tests of significance are used to determine the extent to which traits found in a sample of a population are representative of the population as a whole. No sampling was used in our study. As set forth in Appendix B, our data were obtained from an analysis of every argued case decided by the United States Supreme Court between 1946 and 1995. Our figures present comparisons of means for certain defined subsets of this entire population of cases. Thus, all of the results we report, be they the mean number of amicus briefs filed per case per decade or the change in p-win rates under specific parameters of institutional-litigant involvement, are statistically significant because they represent the true figures for an entire population of cases. Including the significance of the data for each figure would be unnecessary and redundant.

The nature of amicus participation has changed greatly over the course of the past fifty years. Many of the figures in the Article attest not just to the increase in the number of briefs filed, but also to increases in citations, quotations, level of involvement by institutional litigants, and other changes. Because of the changing nature of amicus participation across the decades covered in the database, many of the results compare rates and means across markedly different-sized population subsets. Thus an important caveat with regard to the data presented in the figures is that statistical significance alone does not necessarily equate with substantive significance-the relative impact of each of the categories of inquiry on Supreme Court outcomes. It is entirely reasonable to be skeptical of p-win rates produced by a subset of the data that contains only fifteen cases versus one that contains 100 or more; the larger the size of the population, the smaller the variance of the variable will be. Smaller $N$ sizes are much more likely to produce means affected by the presence of outliers; larger population sizes tend to mitigate the likelihood of random chance outcomes driving the data. For this reason, we have in each figure included the number of cases falling within each category to allow the reader to make judgments about the robustness of the reported results.

Ultimately, our project seeks to determine whether amicus briefs 
have any influence on who wins and loses in cases brought before the Court. Thus, it was important to move beyond a comparison of $p$-win rates and develop a model that could inform this core question. Logit regression allows us to accomplish this by measuring the effects of different variables on the probability of producing an outcome favorable to petitioner. ${ }^{1}$ Logit uses a dependent variable coded either 1 or 0 : either the dependent variable occurs or it does not. In this case, the dependent variable was a p-win: either the case resulted in a win for petitioner or it did not. The dependent variable "PWINONLY" was a filter variable, recoding each case in the database $(N=6141)$ into 1 or $0 ; 1$ if the Court ruled in favor of the petitioner, 0 if the Court ruled in favor of the respondent or if a mixed result was reached. ${ }^{2}$

The question driving our research is what impact specific arrangements of participants and levels of amicus filing activity would have on Court outcomes: e.g., what would be the outcome if a specific party filed as amicus? In order to address this question, each of the independent variables was coded as a dummy variable, where the category of interest was either present in a specific case or not (1 or $0)$. This allowed us to assess the influence of specific case parameters on the dependent variable; we did not include independent variables that would be coded in a continuous ordinal manner such as total number of briefs filed.

Table I sets forth the results for the regression used in conjunction with Figures 11 and 12 in Part V.B.

${ }^{1}$ For general explanations of logit regression, see AlAN AGRESTI \& BARBARA FinLAY, STATISTICAL METHODS FOR THE SOCIAL SCIENCES 482-92 (2d ed. 1986); JOHN H. AIDRICH \& FOREST D. NELSON, LINEAR PROBABIIITY, LOGIT, AND PROBIT MODEIS 48-66 (1984); MICHAEI O. FINKELSTEIN \& BRUCE LEVIN, STATISTICS FOR LAWYERS 447$52(1990)$.

${ }^{2}$ We omitted the mixed results in this model since a mixed result does not lend itself to probability analysis in any substantive manner. Absent data on the issues on which the party wins, the issues on which the party loses, and the issues that each amicus brief had addressed, no meaningful correlation can be made between the amicus brief and the mixed outcome. When we ran the model combining mixed results with p-wins (from "PWINONLY" into "PWINMIX"), it did not significantly alter the results. 
Table I

Dependent variable $=$ Case outcome is $p$-win $*$

\begin{tabular}{|c|c|c|c|c|c|}
\hline CASE VARIABLE & $\begin{array}{l}\text { PARAMETER } \\
\text { ESTIMATE }\end{array}$ & $\begin{array}{l}\text { STANDARD } \\
\text { ERROR OF } \\
\text { THE } \\
\text { ESTIMATE } \\
\end{array}$ & $\begin{array}{l}\text { SIGNIFI- } \\
\text { CANCE }\end{array}$ & ESTIMATE R & $\begin{array}{l}\text { ODDS RATIO: } \\
\text { EXP(B), AT } \\
\text { A } 95 \% \\
\text { CONF. INT. }\end{array}$ \\
\hline$S G$ as petitioner & .7284 & .0725 & .0000 & .1092 & $\begin{array}{l}2.0718 \\
(1.7973- \\
2.3883) \\
\end{array}$ \\
\hline $\begin{array}{l}S G \text { as respon- } \\
\text { dent }\end{array}$ & .6370 & .0712 & .0000 & .0970 & $\begin{array}{l}.5289 \\
(.4600 \\
.0681) \\
\end{array}$ \\
\hline $\begin{array}{l}\text { SG as amicus } \\
\text { supporting peti- } \\
\text { tioner }\end{array}$ & .8418 & .1067 & .0000 & .0852 & $\begin{array}{l}2.3205 \\
(1.8827 \\
2.8601) \\
\end{array}$ \\
\hline $\begin{array}{l}\text { SG as amicus } \\
\text { supporting re- } \\
\text { spondent }\end{array}$ & -.9828 & .1297 & .0000 & .0817 & $\begin{array}{l}.3743 \\
(.2903 \\
.4826) \\
\end{array}$ \\
\hline $\begin{array}{l}1-0.0 \text { cases; } S G \\
\text { filtered out as } \\
\text { amicus }\end{array}$ & .2405 & .1104 & .0294 & .0182 & $\begin{array}{l}1.2719 \\
(1.0244 \\
1.5793) \\
\end{array}$ \\
\hline $\begin{array}{l}2-0-0 \text { cases; } S G \\
\text { fillered out as } \\
\text { amicus }\end{array}$ & .4029 & .2024 & .0465 & .0154 & $\begin{array}{l}1.4962 \\
(1.0062- \\
2.2249) \\
\end{array}$ \\
\hline $\begin{array}{l}>2-0-0 \text { cases; } \\
\text { SG filtered out } \\
\text { as amicus }\end{array}$ & -.1871 & .2333 & .4225 & .0000 & $\begin{array}{l}.8294 \\
(.5250- \\
1.3101) \\
\end{array}$ \\
\hline $\begin{array}{l}0-1-0 \text { cases; SG } \\
\text { fillered out as } \\
\text { amicus }\end{array}$ & -.2330 & .1158 & .0441 & -.0157 & $\begin{array}{l}.7921 \\
(.6313- \\
.9939) \\
\end{array}$ \\
\hline $\begin{array}{l}\text { O-2-O cases; SG } \\
\text { filtered out as } \\
\text { amicus }\end{array}$ & -.6028 & .1852 & .0011 & .0322 & $\begin{array}{l}.5473 \\
(.3807- \\
.7868) \\
\end{array}$ \\
\hline $\begin{array}{l}0 \rightarrow 2-0 \text { cases; } \\
\text { SG filtered out } \\
\text { as amicus }\end{array}$ & -.3257 & .2118 & .1241 & -.0066 & $\begin{array}{l}.7220 \\
(.4767- \\
1.0936) \\
\end{array}$ \\
\hline Constant & .3339 & .0420 & .0000 & & \\
\hline
\end{tabular}

*significant variables at $p<.05$ level in italics 
The "Parameter Estimate" in Table I indicates how the dependent variable changes, and in what direction, when an independent variable changes from 0 to 1 , holding all other variables constant. For instance, the Parameter Estimate for the variable "SG as petitioner" tells us that when the variable increases from 0 to 1 -that is, when the Solicitor General represents the petitioner in the case-the log odds of a p-win increase by .7284 .

The "Standard Error of the Estimate" describes the spread of the distribution of the estimate; it refers to the variability of the value. Generally, the larger the subset of cases that falls within each variable, the smaller the Standard Error of the Estimate will be. The "Significance" column shows the level at which the estimate for each variable is statistically significant within the model. Independent variables that are significant at the $p<.05$ level, the standard cut-off, are shown in italics.

It is particularly important for the purposes of this study to assess the robustness of the statistically significant variables. The "Estimate $\mathrm{R}$ " measures the strength of the relationship between the independent variable and a p-win. Essentially, it is an interpretation of the strength of the association provided by the Parameter Estimate. The variables that are not statistically significant have $R$ 's at zero or close to zero, implying that the coefficients may be the result of chance or spurious behavior. The range of $R$ is from -1 to 1 : a score of 1 is a perfect positive association, while a score of -1 is a perfect negative association. The sign ( $+/-$ ) of $R$ indicates the direction of association: positive and negative numbers are equally strong in measuring the strength of association.

As evidenced by Table I, none of the variables have particularly large R's, and we can surmise that even the statistically significant variables are not particularly robust in explaining individual case outcomes, controlling for other factors. ${ }^{3}$ We are not distressed by this, however. We have made no attempt to develop a model that would robustly predict Supreme Court outcomes by taking into account the wide variety of factors that influence the Court. Rather, our limited objective is to use logit regression models to corroborate what we find through a comparison-of-means analysis about one slice of the universe of factors that arguably influence the Court-amicus briefs.

The far right column, "Odds Ratio: $\operatorname{Exp}(\mathrm{B})$ " (Exponent of B),

${ }^{3}$ Indeed, the Nagelkerke $\mathrm{R}^{2}$ for the models reflected in Tables I and II is .090 and .096 , respectively, telling us that less than $10 \%$ of the variation in the p-win outcomes is explained by our models. 
tells us how the presence of each independent variable increases or decreases the odds of a $p$-win. This gives us the ratio of the probability of a p-win when a variable is 1 (present in a case) compared to the probability of a $p$-win when the variable is 0 (not present). The associated confidence interval tells us the range of values that are plausible for $95 \%$ of the population of cases; if we repeated the procedure, we would expect $95 \%$ of the intervals to contain the estimate $\operatorname{Exp}(\mathrm{B})$. Thus, when the odds ratio equals 2, as reflected in the case of the Solicitor General as petitioner or the Solicitor General filing as amicus on behalf of the petitioner, a $p$-win is twice as likely as it would be if the Solicitor General had not filed as petitioner or as amicus. When the odds ratio equals 0.5 , as reflected in the case of the Solicitor General as respondent, a p-win is half as likely as it would be if the Solicitor General had not been involved as a party. If the $95 \%$ confidence interval includes the value 1 -no change in odds, the status quo benchmark-then we cannot conclude that the presence of a particular variable is associated with either a decrease or increase in the odds of a win for petitioner. The $>2-0-0$ and the $0->2-0$ disparity variables, for instance, include values both greater than and less than 1 . Thus, across $95 \%$ of cases, we cannot predict whether these variables would increase or decrease the odds of a p-win; there are too many cases on both sides for the variable to be effective as a predictor.

All variables are significant in this model except $>2-0-0$ cases (SG filtered out as amicus) and 0 $>2-0$ cases (SG filtered out as amicus). Among the statistically significant outcomes in the model, clearly the Solicitor General is the most robust in influencing Court rulings. The impact of the Solicitor General filing on behalf of petitioner is very large. A case where the Solicitor General files as amicus on behalf of petitioner, holding other influences constant, effectively more than doubles the odds of a win for petitioner. At the same time, the Solicitor General filing as amicus on behalf of the respondent decreases the odds of a p-win by more than $60 \%$-the most robust impact of any of the variables in this model.

The disparity cases follow the pattern we would intuitively expect, given the information reflected in Figures 11 and 12. For each variable, the Solicitor General was filtered out as amicus. With respect to briefs supporting petitioner, the odds of a p-win are increased by a disparity of two briefs to none, relative to one brief to none. Likewise, the disparities on the respondent's side tend to favor respondent in decreasing the odds of a p-win.

It is worth noting that the variables that are not statistically signifi- 
cant should not be interpreted as being wholly irrelevant. These variables may simply be so scattered as to be ineffective predictors of outcomes. The $>2-0-0$ cases, for instance, may have another factor not measured by our study influencing the outcomes so as to render this variable a disadvantage for petitioner (as evidenced by the negative parameter estimate for these cases). As the confidence intervals demonstrate, the influence of this particular variable alone cannot predict whether the odds of a p-win are increased or decreased.

Table II sets forth the results of the regression used in conjunction with Figures 13-22 in Part V.C.

\section{Table II}

Dependent variable $=$ Case outcome is $p$-win $*$

\begin{tabular}{|l|l|l|l|l|l|}
\hline $\begin{array}{l}\text { CASE } \\
\text { VARIABLE }\end{array}$ & $\begin{array}{l}\text { PARAMETER } \\
\text { ESTIMATE }\end{array}$ & $\begin{array}{l}\text { STANDARD } \\
\text { ERROR OF } \\
\text { THE } \\
\text { ESTIMATE }\end{array}$ & $\begin{array}{l}\text { SIGNIFI- } \\
\text { CANCE }\end{array}$ & $\begin{array}{l}\text { ESTIMATE } \\
\text { R }\end{array}$ & $\begin{array}{l}\text { ODDS RATIO: } \\
\text { EXP(B), AT A } \\
95 \% \text { CONF. } \\
\text { INT. }\end{array}$ \\
\hline SG as petitioner & .7229 & .0729 & .0000 & .1080 & $\begin{array}{l}2.0605 \\
(1.7865- \\
2.3765)\end{array}$ \\
\hline $\begin{array}{l}\text { SG as respondent } \\
\begin{array}{l}\text { supporting peti- } \\
\text { tioner }\end{array}\end{array}$ & -.6324 & .0718 & .0000 & -.0955 & $\begin{array}{l}.5313 \\
(.4616 \\
.6116)\end{array}$ \\
\hline $\begin{array}{l}\text { SG as amicus } \\
\text { supportingre } \\
\text { spondent }\end{array}$ & -1.0060 & .1367 & .0000 & -.0793 & $\begin{array}{l}2.5006 \\
(2.0029 \\
3.1220)\end{array}$ \\
\hline $\begin{array}{l}\text { Other amici } \\
\text { besides four } \\
\text { institutional } \\
\text { litigants (SG, } \\
\text { States, ACLU, } \\
\text { AFL-CIO) in 1- } \\
\text { 0-0 cases }\end{array}$ & .0509 & .1132 & .0000 & .0876 & $\begin{array}{l}.3657 \\
(.2797- \\
4780)\end{array}$ \\
\hline
\end{tabular}




\begin{tabular}{|c|c|c|c|c|c|}
\hline $\begin{array}{l}\text { CASE } \\
\text { VARIABLE }\end{array}$ & $\begin{array}{l}\text { PARAMETER } \\
\text { ESTIMATE }\end{array}$ & $\begin{array}{l}\text { STANDARD } \\
\text { ERROR OF } \\
\text { THE } \\
\text { ESTIMATE } \\
\end{array}$ & $\begin{array}{l}\text { SIGNIFI- } \\
\text { CANCE }\end{array}$ & $\begin{array}{l}\text { ESTIMATE } \\
\mathrm{R}\end{array}$ & $\begin{array}{l}\text { ODDS RATIO: } \\
\text { EXP(B), AT A } \\
95 \% \text { CONF. } \\
\text { INT. }\end{array}$ \\
\hline $\begin{array}{l}\text { Other amici } \\
\text { besides four } \\
\text { institutional } \\
\text { litigants in } 2-0-0 \\
\text { cases }\end{array}$ & .2918 & .2604 & .2624 & .0000 & $\begin{array}{l}1.3388 \\
(.8037- \\
2.2303)\end{array}$ \\
\hline $\begin{array}{l}\text { Other amici } \\
\text { besides four } \\
\text { institutional } \\
\text { litigants in } \\
>2-0-0 \text { cases }\end{array}$ & -.3647 & .3442 & .2894 & .0000 & $\begin{array}{l}.6944 \\
(.3537- \\
1.3634)\end{array}$ \\
\hline $\begin{array}{l}\text { Other amici } \\
\text { besides four } \\
\text { institutional } \\
\text { litigants in 0-1-0 } \\
\text { cases }\end{array}$ & -1676 & .1365 & .2192 & .0000 & $\begin{array}{l}.8457 \\
(.6472- \\
1.1050)\end{array}$ \\
\hline $\begin{array}{l}\text { Other amici } \\
\text { besides four } \\
\text { institutional } \\
\text { litigants in } 0-2-0 \\
\text { cases }\end{array}$ & -.3838 & .2445 & .1165 & -.0075 & $\begin{array}{l}.6813 \\
(.4218 \\
1.1002)\end{array}$ \\
\hline $\begin{array}{l}\text { Other amici } \\
\text { besides four } \\
\text { institutional } \\
\text { litigants in } \\
0-2-0 \text { cases }\end{array}$ & -.3736 & .3180 & .2401 & .0000 & $\begin{array}{l}.6883 \\
(.3690- \\
1.2837)\end{array}$ \\
\hline $\begin{array}{l}A C L U \text { as amicus } \\
\text { supporting peti- } \\
\text { tioner }\end{array}$ & .5346 & .1425 & .0002 & .0382 & $\begin{array}{l}1.7068 \\
(1.2910 \\
2.2565) \\
\end{array}$ \\
\hline $\begin{array}{l}\text { ACLU as amicus } \\
\text { supporting re- } \\
\text { spondent }\end{array}$ & -.1975 & .1394 & .1564 & -.0010 & $\begin{array}{l}.8208 \\
(.6246- \\
1.0786) \\
\end{array}$ \\
\hline $\begin{array}{l}\text { AFL-CIO as } \\
\text { amicus support- } \\
\text { ing petitioner }\end{array}$ & -.0477 & .2020 & .8134 & .0000 & $\begin{array}{l}.9534 \\
(.6417- \\
1.4165)\end{array}$ \\
\hline
\end{tabular}




\begin{tabular}{|c|c|c|c|c|c|}
\hline $\begin{array}{l}\text { CASE } \\
\text { VARIABLE }\end{array}$ & $\begin{array}{l}\text { PARAMETER } \\
\text { ESTIMATE }\end{array}$ & $\begin{array}{l}\text { STANDARD } \\
\text { ERROR OF } \\
\text { THE } \\
\text { ESTIMATE }\end{array}$ & $\begin{array}{l}\text { SIGNIFI- } \\
\text { CANCE }\end{array}$ & $\begin{array}{l}\text { ESTIMATE } \\
\text { R }\end{array}$ & $\begin{array}{l}\text { ODDS RATIO: } \\
\text { EXP(B), AT A } \\
95 \% \text { CONF. } \\
\text { INT. }\end{array}$ \\
\hline $\begin{array}{l}\text { AFL-CIO as ami- } \\
\text { cus supporting } \\
\text { respondent }\end{array}$ & -.4814 & .1955 & .0138 & -.0221 & $\begin{array}{l}.6179 \\
(.4212- \\
.9064)\end{array}$ \\
\hline $\begin{array}{l}\text { State as amicus } \\
\text { supporting peti- } \\
\text { tioner }\end{array}$ & .2285 & .1277 & .0736 & .0120 & $\begin{array}{l}1.2567 \\
(.9784 \\
1.6141)\end{array}$ \\
\hline $\begin{array}{l}\text { State as amicus } \\
\text { supporting re- } \\
\text { spondent }\end{array}$ & -.4341 & .1166 & .0002 & -.0378 & $\begin{array}{l}.6479 \\
(.5155 \\
.8143)\end{array}$ \\
\hline $\begin{array}{l}\text { Court cited } \\
\text { amicus support- } \\
\text { ing petitioner }\end{array}$ & .1155 & .1538 & .4526 & .0000 & $\begin{array}{l}1.1225 \\
(.8303- \\
1.5174) \\
\end{array}$ \\
\hline $\begin{array}{l}\text { Court cited } \\
\text { amicus support- } \\
\text { ing respondent }\end{array}$ & -.1681 & .1611 & .2966 & .0000 & $\begin{array}{l}.8453 \\
(.6165- \\
1.1590)\end{array}$ \\
\hline $\begin{array}{l}\text { In 1-1-0 cases, } \\
\text { petitioner's law- } \\
\text { yer more expe- } \\
\text { rienced before } \\
\text { Court }\end{array}$ & .3569 & .2996 & .2336 & .0000 & $\begin{array}{l}1.4289 \\
(.7943- \\
2.5705)\end{array}$ \\
\hline $\begin{array}{l}\text { In 1-1-0 cases, } \\
\text { respondent's } \\
\text { lawyer more } \\
\text { experienced } \\
\text { before Court }\end{array}$ & -.2445 & .2622 & .3511 & .0000 & $\begin{array}{l}.7831 \\
(.4684- \\
1.3092)\end{array}$ \\
\hline Constant & .3401 & .0442 & .0000 & & \\
\hline
\end{tabular}

*significant variables at $p<.05$ level in italics

The Parameter Estimate, Standard Error of the Estimate, Significance, Estimate R, and Odds Ratio in Table II all express the same values as they do in Table I. Significant variables at the $p<.05$ level are again shown in italics.

In this model, none of the disparity-of-amicus-support variables attains significance. Because each of the institutional litigants in the study (Solicitor General, ACLU, AFL-CIO, the States) has been given a dummy variable, they have all been filtered out of the analysis of dis- 
parities of amicus support to avoid duplication of effects. Either because this reduced the number of cases presenting disparities, or because the other institutional litigants (besides the Solicitor General) are responsible for much of the effect of disparities in Table 1, we find no significant relationship between disparities of amicus support and court outcomes.

In contrast, the significance and influence of the Solicitor General in the more complete model remain roughly as robust as in the first model. The impact of other institutional litigants is highly varied. The ACLU is the only one of the three that has a statistically significant impact when it files on behalf of petitioner, increasing the odds of a p-win; the AFL-CIO and States each have an impact toward decreasing the odds of a p-win when filing on behalf of respondent, but show no consistent pattern of influence when supporting petitioner. It is also likely that the spread of case outcomes in the subset population, particularly in the AFL-CIO amicus filings on behalf of petitioner, was simply too wide and random to produce an effective predictor variable.

Noticeably, neither the "citation" variables nor "experience" variables achieved a measure of statistical significance. Judging from the varied spread of possible increases or decreases in odds of a $p$-win when any of these four variables is present, it is likely that these factors by themselves do not hold much influence. Whether or not cases in these categories are p-wins or p-losses is more dependent on a host of other variables. 
$* \quad * \quad * \quad * \quad * \quad *$

HeinOnline -- 148 U. Pa. L. Rev. 856 1999-2000 